\title{
Agrocropolis \\ Vertical Farming in Toronto's Distillery District
}

By

Jaclyn $\mathrm{Ng}$

A thesis submitted to the Faculty of Graduate and Post Doctoral Affairs in partial fulfillment of the requirements for the degree of

Master of Architecture

Carleton University

Ottawa, Ontario

() 2014

Jaclyn $\mathrm{Ng}$ 


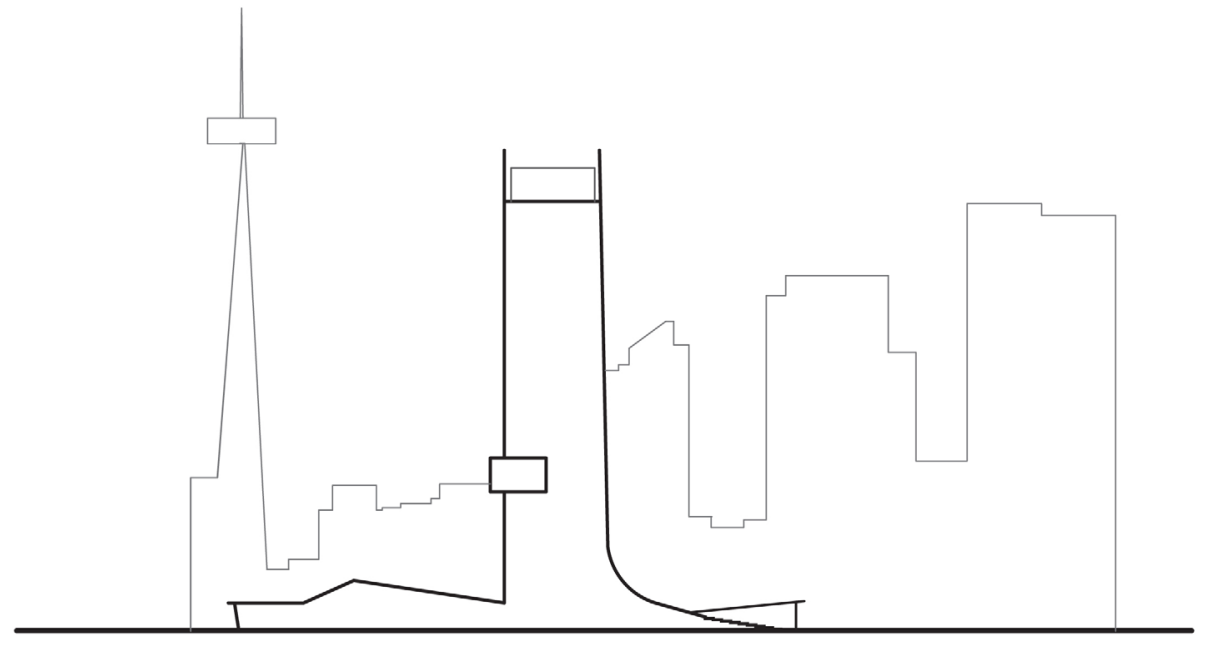




\section{Abstract}

This thesis proposes a city block farming structure that aims to implement strategies of neighbourhood self-sufficiency within the core of Toronto. It will research the new marketplace demand for local and fresh produce across North America as an alternative to the current globalized food model based on a "just-in-time" delivery system. This investigation is significant because cities such as Toronto are seeking different means to bring local produce and farming into the urban context. This thesis will analyze the past and present status of Toronto's food and agricultural industry in order to propose a scheme that will maximize the economic and social benefits for urban neighbourhoods. Developing systems such as hydroponics will be explored as a means to bring year-round farming techniques into a structure that will grow, harvest, and sell produce in the city centre. The thesis project will suggest a tower design that will service the neighbourhood's intermediate needs through a podium level food market, create a relationship with its surrounding neighbourhood, as well as improve the quality of the community through integrated urban design strategies. 
Table of Contents

\section{Table of Contents}

\section{A} Section A

ii. Abstract

iii. Table of Contents

1 Introduction

1 Section 1: Food and the City

3 Toronto's Modernization of Food Production

5 Toronto's Early Food Markets

8 Globalization and Scaling

2

Section 2: The Modern Farming Industry

12 The Agrochemical Industry

14 Land and Ecological Resource Usage

15 Food Miles and Carbon Footprint

3 Section 3: The New Food Movement

20 Local Food Movements

23 Toronto and the New Food Movement

4 Section 4: Systems

27 Technological Development

28 Hydroponics

30 Aquaponics

31 Aeroponics

5

Section 5: The Vertical Farm

34 Despommier's Vertical Farm

35 Epcot, Disneyworld

36 FarmedHere

37 Suwon, Korea

38 The Design Project

6

Section 6: The Design

41 Introduction

42 The Site

50 The Distillery District

52 Programming

59 The Market

60 The Crops

B Section B:

92 Conclusion

94 Appendix

C Section C: Bibliography 97 Bibliography 100 Secondary Bibliography 101 Image Bibliography 


\section{Introduction}

This thesis attempts to use architecture as a means to create social awareness for issues concerning food as well as creating food security within Toronto. In the past century, the relationship between Toronto and its food has changed as technology has advanced and culture has evolved. Toronto began as a self-sufficient city, with local farmers and businesses providing for the city's basic food needs. As the city industrialized, agricultural and food processing practices increased in efficiency and standards progressed. The number of Toronto's food manufacturing factories rapidly multiplied in numbers and globalization expanded the city's import and export capabilities. Currently, concern has risen for repercussions of the mechanization and spread of the global food industry. Documentaries such as "Food Inc." directed by Robert Kenner and literature such as "The End of Food" by Thomas Pawlick demonstrate this concern in commercial media. Carbon footprint, the use of chemicals in farming, and ecological resource management has become common concerns highlighted by food movements. Toronto has consistently been at the forefront of food movements and policy-making, and demand for local food and markets have risen, resulting in an increase of markets when demand for local food rose. Yet, even with the increase in locally sourced food, achieving a level of self-sufficiency is far from reach. Although greenhouses and community gardens have been emerging all over the city of Toronto, their scale is not substantial enough to support the communities in which they reside.

Presently, contemporary technologies such as hydroponic systems are being advanced in order to maximize space for the indoor growing of crops. In the application of these systems, productivity of current greenhouses could multiply considerably. The distillery district neighbourhood was the site chosen for the thesis project with the aim to provide the area with basic food needs and community space through a farming tower and market. 


\section{Section 1 : Food and the City}

"More and more people are participating in a public ethic of production... There's little doubt that now, too, many, many people have limited access to fresh, healthy food due to a whole host of economic and social conditions, but the hunger being met headon by today's community food projects encompasses food access and, also, more. The orchard in Ben Nobleman Park, for example, is about more than fruit. It's about reimagining our city - and our

place as citizens within it - as productive and generative ${ }^{1} . "$

- Lorraine Johnson

(Toronto based author of City Farmer: Adventures in Feeding Ourselves) 


\subsection{Toronto`s Early Food Markets}

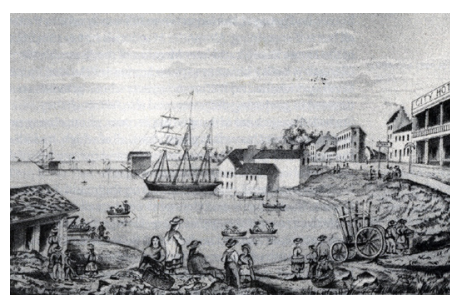

Image 1. York's fish market depicted in 1830.
* The Town of York was founded in 1793 by British colonials which eventually grew to become the City of Toronto.

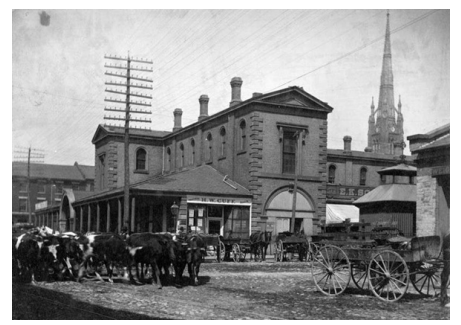

Image 2. St. Lawrence Market in the 1880s.

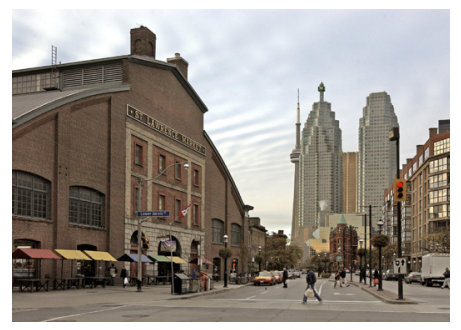

Image 3. Present day St. Lawrence Market
The city of Toronto owes much of its current character to its history of food markets and food production. Two of Toronto's most commonly used nicknames are attributed to food: Hogtown and Cabbagetown. The nickname "Hogtown" refers to early Toronto's prominence as a pork packaging hub in Canada while "Cabbagetown" is a moniker given to the Irish immigrants who grew cabbages in their front yards in the mid 19th century². Until 1845, Cooper's Wharf, located at the foot of Church St. was the primary shipping and receiving area for food import and exports ${ }^{3}$. As the city's food industry grew, Union Station became the import/export hub as a growing number of local food manufacturers began sending and receiving shipments via local rail lines ${ }^{4}$. As a result, Front St. intensified as a shipping area and the shoreline was extended into the bay. In the early 19 th century, the residents of York* could buy fresh fish caught in the harbour at an informal beachfront market assembled near Berkeley Street and Front Street ${ }^{5}$.

Prior to the early 20th century conception of the supermarket, communities would depend on many different market vendors to provide fresh and local produce for their tables. In 1803, Lieutenant-Governor Peter Hunter established the first regulated market in Toronto on the site of the present St. Lawrence Market ${ }^{6}$. The first St. Lawrence Market building housed vendors that sold a wide variety of fresh agricultural produce and meat such as deer. By 1850, the St. Lawrence Market had become the 
Food and the City

social centre of the city as it played host to public meetings, concerts, exhibitions, and lectures ${ }^{7}$. St. Patrick's Market was constructed twenty nine years later in 1832. Though it did not hold as much importance or space as St. Lawrence, it sufficiently provided farmers' produce for the residents of the surrounding neighbourhood, which is the present day Fashion District. The 1850's witnessed the creation of St. Andrew's Market, nicknamed The Western Market, Toronto's third permanent market building and its second largest. The neighbourhood surrounding the market eventually grew into a centre for industrial production and workers' housing ${ }^{8}$. By 1861, Toronto's population of 45,000 was well-served by these three public market buildings ${ }^{9}$. In the late 1800's, many shopkeepers began refusing to pay market fees and success of the market diminished, and ultimately the market stalls were all gone by $1900^{10}$. The St. Patrick's Market was designated a heritage site in 1975 and the building currently sits along present-day Queen St. West ${ }^{11}$. Currently, St. Lawrence Market still remains fully functional at the intersection of Front St. And Lower Jarvis St. while the site of St. Andrews Market has since been converted into a park. In 2009, a citizen's group began pushing for the revival of St. Andrew's Market in order to establish a need for social connection and access to healthy food within the neighbourhood.

The 20th century brought many diverse groups of new immigrants into the city of Toronto. The early 1900's welcomed the rapid development of the Kensington neighbourhood, quickly nicknamed the "Jewish Market". The growing population of Jewish immigrants meant higher demand in certain niche products such as kosher meats. In time, families began selling produce out of the first floor of their own homes which fused the residential neighbourhoods with niche businesses and created the Kensington Market ${ }^{12}$. Toronto's Chinatown began development around the same time as Kensington Market. After the construction of the Canadian Pacific Railway, hundreds of Chinese men migrated to Toronto and Chinatown became a defined community by $1930^{13}$. After its destruction for the new City Hall building in 1961-65, Toronto's Chinatown relocated beside Kensington Market along Spadina Ave. With a strong history rooted in food markets, many surviving markets and districts within the city still play a crucial role in the everyday life of Toronto's residents. 


\subsection{Toronto`s Modernization of Food Production}

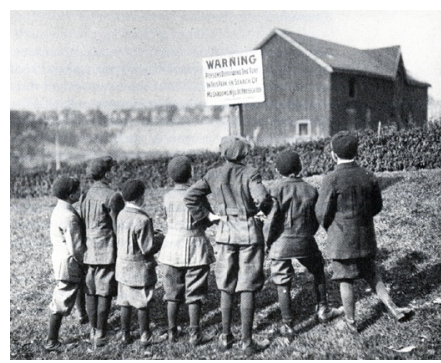

Image 4. Locals were forbidden to gather mushrooms in Willowvale Park (now Christie Pits) in 1914

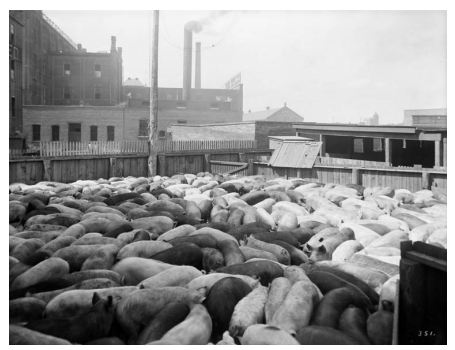

Image 5. Hogs in the William Davies Company pen in Toronto, circa 1920's
Prior to today's contemporary approach of accessing food through supermarkets and delivery systems, cities such as Toronto were effectively self-sustainable. In the 1800's, most homes in Toronto grew food in household gardens primarily for their own consumption. Ducks and other birds were shot at Gibralter Point and the local landscape offered many types of fare such as honey, maple sugar and syrup, mushrooms, wild berries, herbs, greens, and edible roots ${ }^{14}$. It was also noted that one could pick edible sorrel near St. James Cathedral at the intersection of King St. and Church St. in the 1830's ${ }^{15}$. After World War I, interest in urban food growing made a provisional dip until the Great Depression. In 1934, a 90 hectares plot of land was transformed into a community garden and provided food for 5000 unemployed families ${ }^{16}$. Hundreds of small market gardens and greenhouses were also set up within the city and inner suburbs, producing a large percentage of Toronto's vegetables and fruit, along with processors of poultry, dairy, eggs, and meat. Although all of the greenhouses have disappeared, traces of their existence still survive to this day such as the parking lot along upper Christie St., which used to be a set of market gardens and greenhouses that lined the street ${ }^{17}$.

In the late 19th century, William Davies opened Toronto's first large scale hog slaughtering facility to give Toronto one its most popular nicknames: Hogtown ${ }^{18}$. His plant was the first in Canada to introduce artificial refrigeration and the business used 
Food and the City

the expanding rail network to increase its scale. Many stock yards, abattoirs and meat packing plants were located inside the Toronto core and as they grew in number and size, it compromised the quality of urban life through foul odours, waste disposal, and transportation ${ }^{19}$. The introduction of a provincial legislative meat inspection as well as the federal Meat and Canned Food Act was passed by Parliament in $1907^{20}$. After the introduction of the Meat and Canned Foods Act, there was significant improvement in the cleanliness of large scale slaughterhouses.

At the turn of the 20th century, industrialized nations became increasingly more efficient in the production of food. The discovery of oil, the development of the internal combustion, and the use of explosives for clearing land all contributed to the advancement of agriculture ${ }^{21}$. By 1907, Henry Ford created the assembly line and was also credited with the invention of a diesel powered tractor ${ }^{22}$. New machines such as tractors, combines, and other mechanized farming equipment allowed farmer to work, plant, and harvest a much larger area ${ }^{23}$. The number of industrial food manufacturing plants in Toronto rose with the completion of newly built steam powered railroad networks, which also intensified the possibilities of food production and expanded the market for food. Commercial bakers soon multiplied along the rail line and a baking district formed around the intersection of Dupont St. and Bathurst St. ${ }^{24}$. By the 1920's, this included Western Canada Flour Mills, Maple Leaf Milling, and Harry Webb Co. ${ }^{25}$. International demand spurred local farmers and butchers to produce more meat for export and other types of food production facilities also began to cluster along the rail lines.

During World War II, citizens of Toronto were encouraged to plant vegetables, herbs, and fruit in victory gardens to support the war effort by increasing the amount of commercial produce sent to armed forces and creating food security for those within the city ${ }^{26}$. The mayor of Toronto, Fred Convoy, inspired community support for victory gardens through his speech in June 1943:

"All over Toronto...(m)any a head is bowed over the weeds, many a back is bent over the hoe in backyards and on vacant lots these sunny evenings and weekends. Soon there will be homegrown vegetables on tables in many part of town, and they will taste like food of the gods. ${ }^{27}$ " 


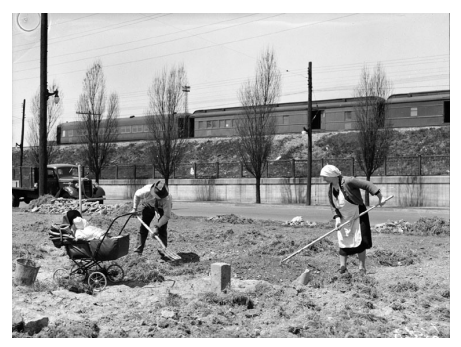

Image 6. Mr. And Mrs. Sandy Stefanik at their Victory Garden plot in the Fleet Street gardens May 9, 1940
As a result, there were a total of 425 gardens in Toronto alone and $\$ 30,940$ ( $\$ 385,741$ in present day) worth of food was produced during the war ${ }^{28}$. Nationally, Canadian cities produced 115 million pounds of food for the war effort in the year 1943 alone $^{29}$. In observing Toronto's past efforts, the possibility of present day food self-sustainability may be a feasible prospect.

Since the 1950's, market gardens, orchards, and greenhouses for food had been classified as industries and were no longer permitted where people lived ${ }^{30}$. There was an ever-expanding selection of prepared food in the 1950s-1960s when frozen TV dinners became popularized ${ }^{31}$. Many food manufacturing businesses were introduced to the city of Toronto with the intention of exporting their food products around the world. Harris Abattoir opened a plant with the capacity to slaughter and process 500 head of cattle a week for export to the British market ${ }^{32}$. After winning a biscuit competition at the Canadian National Exhibition in 1858, William Christie and Alexander Brown created Christie Brown \& Co. at 626 Yonge St. $^{35}$. George Weston founded the Canada Bread Company and established his company as the largest baker in Canada while William Neilson founded William Neilson Ltd., a successful manufacturer of ice cream ${ }^{34}$. Redpath Sugar also opened a factory at Queens Quay East in 1959 and still operates there to this day. 


\subsection{Globalization and Scaling}

When Clarence Saunders opened the first Piggly Wiggly self-service market in 1916, it created a grand shift away from traditional methods in which people accessed their food ${ }^{35}$. By 1932, there were 2660 grocery stores in which customers could carry a shopping basket around the store and hand pick their food items ${ }^{36}$. Today, with the advent of globalization and contemporary modes of transportation, the average grocery store in North America has 28,718 different food items to choose from ${ }^{37}$. Although food not native to the Toronto geographical region has become available to the city through importation, $75 \%$ of the biological diversity of food has been lost as a result of industrialized agriculture ${ }^{38}$. As the journey from production to store for some foods can be a long one, the only foods that make it to supermarket shelves are those that can survive the journey. For example, there are hundreds of types and shapes of tomatoes that exist but consumers are only given the choice of the few types that can survive the journey along the industrial food chain. The grocery store systems operate on concepts of high efficiency, with just-in-time long-distance supply chains. These operating systems have become so efficient that most North American cities have little more than three day's worth of imported food supply at any given time ${ }^{39}$. This can cause strain due to unforeseen events such as border closures, environmental catastrophes, and other crises could empty supermarket shelves within days.

The norm of meat production within large food corporations is a system called "Concentrated Animal Feedlot Operations (CAFOs) ${ }^{40}$. This system describes factory farms with thousands of heads of cattle that are fed high calorie diets to put on weight and fat as quickly as possible within limited space. As food companies continued to experience growth with globalization and corporate acquisitions, smaller domestic farmers were forced to scale up and compete with the global market or withdraw from the industry ${ }^{41}$. This enabled large operations to maximize the use of economies of scale as companies competed to buy up the farmland and aggregate landholdings leftover by extinct family farms ${ }^{42}$. This allowed a higher production rate for meat such as beef, 
Section 1 :

Food and the City

poultry, and pork and a better guarantee for stable and low prices.

In 2008 the five year employment growth in the food manufacturing sector for the Toronto Census metropolitan area was $22 \%^{43}$. This has been beneficial not only to citizens of the city but the economy of Toronto as well. Today, Toronto is the second largest foodprocessing hub. It has about 1600 food processors within the city and its surrounding region ${ }^{44}$. With half of Canada's top ranked food companies headquartered in Toronto, the city is the key decision-making centre for Canada's food processing industry ${ }^{45}$. As these companies continue to grow, the food manufacturing sector as a whole continues to grow as well. 
Food and the City

\section{Section 1 Endnotes}

1. Johnson, Lorraine. "Revisiting Victory, Garden Past, Garden Future." in The Edible City: Toronto's Food from Farm to Fork, edited by Christina Palassio and Alana Wilcox,64. Toronto: Coach House, 2009.

2. Cockrall-King, Jennifer. Food and the City: Urban Agriculture and the New Food Revolution. Amherst, NY: Prometheus, 2012.

3. Hood, Sarah B. "Pickerel, Pork, and Presidents Choice: A Historical Food Map of Toronto." in The Edible City: Toronto's Food from Farm to Fork, edited by Christina Palassio and Alana Wilcox, 14-21. Toronto: Coach House, 2009.

3. Hood 2009, 14-21

4. Hood 2009, 14-21

5. Hood 2009, 14-21

6. Hardwicke, Chris. "Reviving St. Andrew's Market." in The Edible City: Toronto's Food from Farm to Fork, edited by Christina Palassio and Alana Wilcox, 246-251 Toronto: Coach House, 2009

7. "A Little Piece of History". St. Lawrence Market. Accessed March 27, 2014 <http://www.stlawrencemarket.com/history>

8. Hardwicke 2009, 245-251

9. Hardwicke 2009, 245-251

10. Hardwicke 2009, 245-251

11. "Toronto's Architectural Gems-the St. Patrick's (Queen St.) Market | Historic Toronto." Historic Toronto. Accessed December 22, 2013

<http://tayloronhistory.com/2013/10/27/torontos-architectural-gemsthe-st-patricks-queen-stmarket/>.

12. "Kensington Market Historical Society." Kensington Market Historical Society. Accessed December 22, 2013.

" "Toronto Chinatown. kmhs.ca/a-residential-marketplace/>.

14. Hood 2009, 14-21

town." History. Accessed December 23, 2013.

15. Hood 2009, 14-21

16. Johnson $2009,58-65$

17. Farm, Mark. "Greenhouse Toronto, Once Upon a Time" in The Edible City: Toronto's Food from Farm to Fork, edited by Christina Palassio and Alana Wilcox, 140-147. Toronto: Coach House, 2009

18. Hood 2009, 14-21

19. Dotan, Hamutal. "For the Love of a Good Burger." in The Edible City: Toronto's Food from Farm to Fork, edited by Christina Palassio and Alana Wilcox, 160-165. Toronto: Coach House, 2009.

20. Dotan 2009, 164

21. Despommier, Dickson D. The Vertical Farm: Feeding the World in the 21st Century. New York: Thomas Dunne/St. Martin's, 2010

22. Despommier 2010, 24

23. Despommier 2010, 24

24. Hood 2009, 14-21

25. Hood 2009, 14-21

26. Johnson $2009,58-65$

27. Johnson 2009 , $58-65$

28. Johnson 2009, 58-65

29. "Grow TO: An Urban Agriculture Action Plan for Toronto (2012)." Toront Food Policy Council, Oct, 2012. Accessed Sept 16, 2013

30. Farm 2009, 14-147 <http://tfpc.to/wordpress/wp-content/uploads/2012/08/GrowTO_ActionPlan_Oct161.pdf>

31. Cockrall-King 2012, 37

32. Dotan 2009, 160-165

33. Hood 2009, 14-21

34. Hood 2009, 14-21

35. Cockrall-King 2012, 26

36. Cockrall-King 2012, 26

37. Cockrall-King 2012, 27

38. Cockrall-King 2012, 28

39. Cockrall-King 2012, 12

40. Cockrall-King 2012, 53

41. Cockrall-King 2012, 49

42. Cockrall-King 2012, 49

43. Biggs 2009, 32-37

44. Biggs 2009, 32-37

45. Biggs 2009, 32-37 


\section{Section 2 : \\ The Modern Farming Industry}

"Agriculture is now a motorized food industry, the same thing in its essence as the production of corpses in the gas chambers and the extermination camps, the same thing as blockades and the reduction of countries to famine, the same thing as the manufacture of hydrogen bombs ${ }^{1}$."

- Martin Heidegger

(German philosopher and writer) 


\subsection{The Agrochemical Industry}

* Monocropping: the use of land for growing only one type of crop

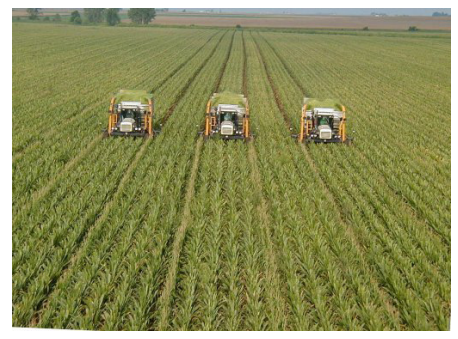

Image 7. Monocropping
In recent years, science and innovation have further advanced farming techniques to industrialize the process of crop cultivation. Large farms have found techniques for maximizing land use and crop gains through monocropping* and ammonium nitrate based products such as pesticides, herbicides, and fertilizers. Between the years 1950 and 1980, global food production and crop yields accelerated considerably ${ }^{2}$.This allowed farmers to increase their crop yields by decreasing the number of crops affected by pests and disease. The agrochemical industry has grown in scale and importance as its products have slowly become the norm. Although environmental lobbyists have continued to fight for tighter controls over the use of agro chemicals, their efforts have grown less powerful as the agrochemical industry has grown more influential. In the United States of America, there are 443 companies that manufacture at least one major pesticide, which has made it increasingly difficult to regulate pesticide products such as herbicides, insecticides, and fungicides ${ }^{3}$.

All chemicals used in agriculture have specifically been created to treat one segment of the farming process, which means there are potentially large numbers of different chemicals that can be used for one growth cycle. Readily available chemical fertilizers, pesticides, and other chemical treatments to the soil have extended the use of land which would otherwise exhaust the soil within just a few harvests ${ }^{4}$. Antibiotics have also allowed 


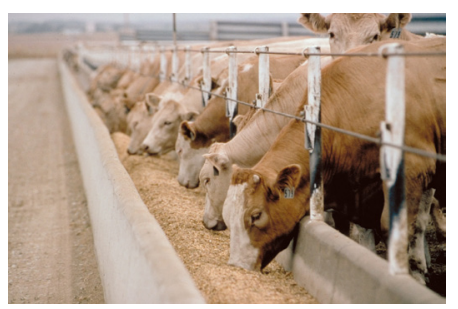

Image 8. Concentrated Feedlots concentrated feedlots in order to capitalize on the number of animals for sale that would otherwise be sick and unsuitable for slaughter. Today, all large scale farming practices are dependent on fossil fuels and agrochemicals for commercially sold food. Environmental impacts of these practices, which started in the 1950 's, have been highlighted to the public in the past decades. About $70 \%$ of the planet's available freshwater is used for irrigation ${ }^{5}$. The agricultural runoff resulting from farming is typically fused with leftover herbicides, fungicides, salts, and fertilizers, which are then returned back to the rivers and streams. The environment and ecosystems have begun to react to the continuous use of agrochemicals. Soil depletion and erosion, increased greenhouses gases, loss of ecology, and water contamination and runoff are direct consequences of the increased use of chemicals in today's agricultural practices. In 2008, the UNFAO released a report titled "Coping with Water Scarcity: An Action Framework for Agriculture and Food Security" addressing the effects of contemporary farming practices on the earth's fresh water supply ${ }^{6}$. 


\title{
2.2 Land and Ecological Resource Usage
}

It is estimated that about $90 \%$ of the earth's arable land is already in use while $70 \%$ of the world's fresh water is currently in use for agriculture ${ }^{7}$. The United Nations Food and Agricultural Organization (UNFAO) have calculated that the total global population in the year 2050 will be 9.2 billion people, 2 billion more than our current world population ${ }^{8}$. It is estimated that the amount of land needed will be equivalent to the size of Brazil ${ }^{9}$. With a growing world population and a decreasing amount of ecological resources, a global food crisis can become a possibility.

\section{Feeding the World: Another Brazil}

\begin{abstract}
Growing food and raising livestock for 6.8 billion people require land equal in size to South America. By 2050 another Brazil's worth of area will be needed, using traditional farming; that much arable land does not exist.
\end{abstract}
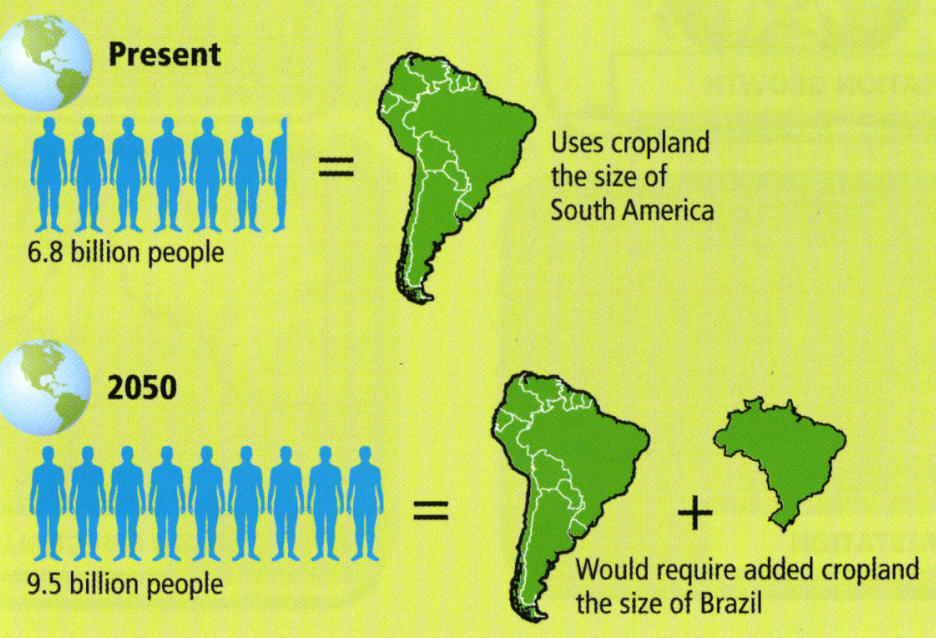

Image 9. If we continue to farm in the traditional fashion, we would need another Brazil's worth of land to produce crops 


\subsection{Food Miles and Carbon Footprint}

* Food Miles: The distance that a food travels from farm production to the consumer's table.

* Carbon Footprint: the amount of greenhouse gases and specifically carbon dioxide emitted by something (as a person's activities or a product's manufacture and transport) during a given period
The local food movement dictates that eating locally produced food will reduce food miles ${ }^{*}$, which in turn would decrease negative impact on the environment. According to the Worldwatch Institute, food travels an average of 1500 to 2500 miles from farm to fork in the average North American diet ${ }^{10}$. Reducing food miles to decrease the carbon footprint* size of food is the main cause taken up by most local food initiatives. Media and books such as "The 100-Mile Diet: A Year of Local Eating" by Canadian authors Alisa Smith and J.B. MacKinnon advocate eating local as a citizen's responsibility to the environment. Indeed, the tagline for the book is a direct quote from Canadian environmentalist David Suzuki: “Eating locally isn't just a fad - it may be one of the most important ways we save ourselves and the planet." Though eating local can reduce carbon dioxide emissions from transportation, local is not always environmentally friendlier. Pierre Desrochers, a geography professor from the University of Toronto, challenges the idea of only eating locally grown food. In the United States, transportation of food accounts for less than $10 \%$ of the energy used to get food from a farm to a consumer, while food production takes up $80 \%$ of the energy ${ }^{11}$. According to Desrochers, "long-distance food transportation by highly efficient diesel container ships represents only a tiny percentage of the total energy used in agricultural production. ${ }^{12}$ "Most greenhouse gas and fossil fuel emissions result before any food product is even transported ${ }^{13}$. This means that eating imported food can be more environmentally friendly 
The Modern Farming Industry

*Vegan: is someone who, for various reasons, chooses to avoid using or consuming animal products. While vegetarians choose not to use flesh foods vegans also avoid dairy and

eggs, as well as fur, leather, wool, down, and cosmetics or chemical products tested on animals. than eating local because food production output can also vary depending on the processor. For example, the British consumer should actually eat salmon imported from Norway than eat the salmon harvested by their Scottish neighbors ${ }^{14}$. Greenhouse gas emissions per tonne of salmon were actually double in Scotland compared to Norway, which makes the small percentage of energy used to transport the salmon almost inapplicable in comparison. Food miles can also be increased in terms of the distance travelled by the inputs for production such as compost, hay, nitrogen, grain feeds, etc. to get to producers. Therefore, eating local is much more complicated than just buying food within a certain radius.

Diet choice could have less negative environmental impact than eating local can. Vegans*, regardless of eating local or imported food, use about $90 \%$ less energy than the average North American consumer ${ }^{15}$. If meat was cut out of diets, it would have far more impact on reducing fossil fuel dependency, alleviating global warming and pollution, and water conservation than buying only locally produced food ${ }^{16}$. In many cases, buying imported vegetables is still more environmentally preferable than buying locally sourced meat because of the tremendous amount of energy used to produce the meat. One calorie of beef requires approximately 25 times the amount of energy that is required to produce one calorie of corn ${ }^{17}$. One pound of beef requires 1857 gallons of water to produce compared to 31 gallons for potatoes ${ }^{17}$. Since food production takes up most of the energy used to get food from farm to fork, eating local could make little difference in environmental impact if consumers remain unaware of the high cost of some dietary choices with meat consumption. In order to become more energy efficient, consumers must use a combination of 
Section 2 :

The Modern Farming Industry

* Horticulture: the science and art of growing fruits, vegetables, flowers, or ornamental plants. eating local and in season as well as reducing meat consumption. For this reason the design project will not house livestock, but will focus on horticultural crops such as fruits and vegetables.
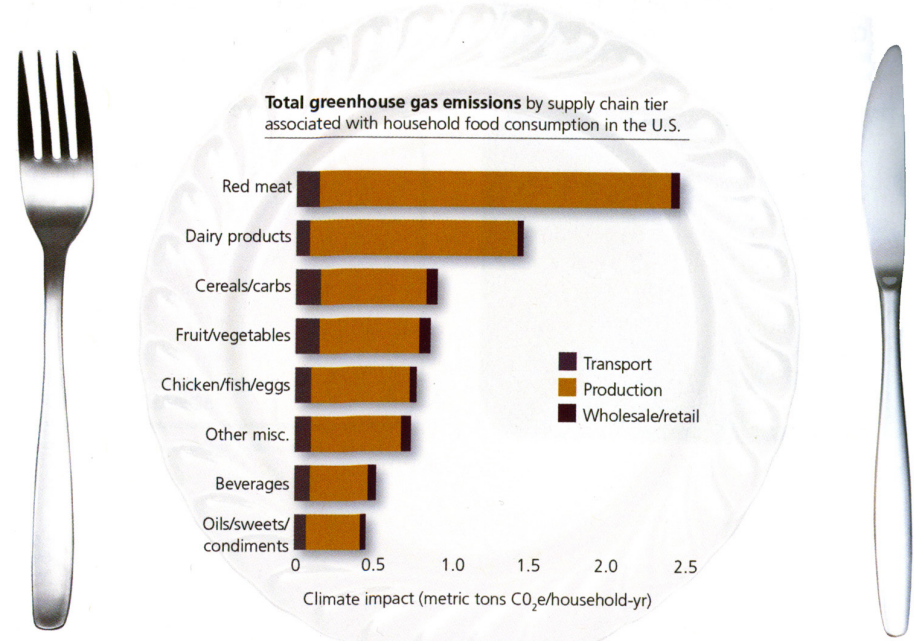

Image 10. Total greenhouse gas emissions 
Section 2 :

The Modern Farming Industry

\section{Section 2 Endnotes}

1. Heidegger, Martin. The Question Concerning Technology. 1954. Accessed March 26.

<http://simondon.ocular-witness.com/wp-content/uploads/2008/05/question_concerning tech nology.pdf>

2. Besthorn, Fred H. "Vertical Farming: Social Work and Sustainable Urban Agriculture in an Age of Global Food Crises." Australian Social Work 66.2 (2013): 187-203. Accessed July 31, 2013. doi:10.1080/0312407X.2012.716448.

3. Despommier 2010, 127

4. Cockrall-King 2012, 24

5. Despommier 2010, 31

6. Coping With Water Scarcity: An Action Framework for Agriculture and Food Security. United Nations Food and Agriculture Organization. 2008.

7. Cockrall-King 2012, 64

8. "How to Feed the World in 2050". United Nations Food and Agriculture Organization. Accessed March 29 2014.

<http://www.fao.org/fileadmin/templates/wsfs/docs/expert_paper/How_to_Feed_the_World_ in_2050.pdf>

9. Despommier 2010,96

10. Halweil, Brian. "Worldwatch Paper \#163: Home Grown: The Case For Local Food In A Global Market." Worldwatch Institute. Accessed January 19, 2014. <http://www.worldwatch.org/node/827>

11. Thomas, Geoff. "What's the Ideal Distance from Farm to Fork?" University of Toronto Magazine Accessed January 19, 2014

$<$ http://www.magazine.utoronto.ca/leading-edge/pierre-desrochers-local-food-debate-mythsgeoff-thomas/>.

12. "What's the Ideal Distance from Farm to Fork?" University of Toronto Magazine

13. Ladner 2011,15

14. Ladner 2011, 18

15. Ladner 2011, 18

16. Ladner 2011, 18

17. Ladner 2011, 18

18. Ladner 2011, 18 


\section{Section 3 : The New Food Movement}

"Toronto is on the cusp of a potential food-market revolution; interest in fresh organic and locally grown foods has expanded in the last decade, and the number of farmers' markets in the city has grown rapidly ${ }^{1} . "$

- Brendan Cormier

(Toronto-based urban designer and planner) 


\title{
3.1 Local Food Movements
}

\author{
The Canadian Food Inspection Agency (CFIA) \\ defines "Local Food" as: \\ - Food produced in the province or territory in which it is sold, or \\ - Food sold across provincial borders within $50 \mathrm{~km}$ of the originating province or \\ territory ${ }^{2}$
}

The farmer's markets, which had nearly disappeared from North American cities between the 1970's and 1990's, have begun to return in the past decade ${ }^{3}$. Consumers have taken a large interest in supporting local farmers and are urging for new markets in which they can access local produce. According to the City of Toronto, buying local can decrease greenhouse gas emissions, increase the freshness and nutritional value of food, and supports the local economy of the city ${ }^{4}$. For developed cities, the urban landscape has become a new frontier to the agricultural industry, where rooftop vegetable gardens are becoming more common and restaurants have begun to grow their own herbs and vegetables. The term urban farming can be described as a

\footnotetext{
* Back-to-the-Land Movement: During the 1960's to 1970's, many North Americans migrated back to the countryside for farming in order to provide food for themselves.
}

"resourceful food gardening in a city setting and farmers are those nobly growing food for themselves, their families, and their community. Unlike the back-to-the-land movement ${ }^{*}$ of the 1970s, this new wave of urban farming isn't about giving up the city life and heading back to the farm but about embracing the notion of the little family farm in the big city. ${ }^{\text {" }}$ 


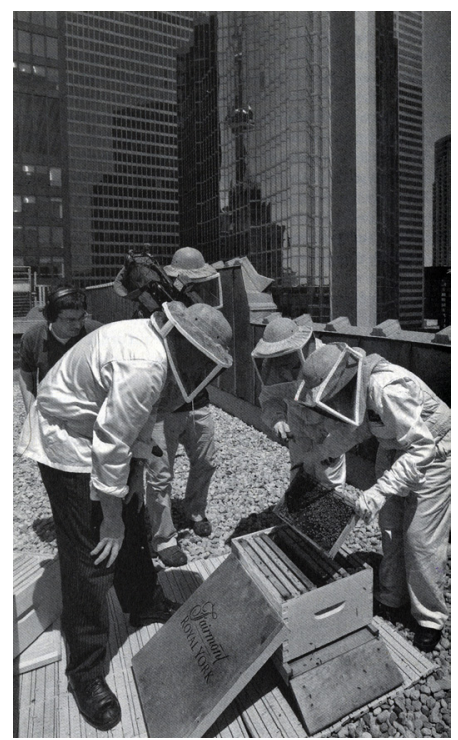

Image 11. Executive Chef David Garcelon and workers tend to the bee hives on the roof of the Royal York Hotel.
Community gardens, urban chickens, public orchards, urban beekeeping, and commercial farms have found their way into city centres ${ }^{6}$. Within the cityscape of Toronto, many endeavors have already begun to urbanize food production. At the Fairmont Royal York Hotel, executive chef David Garcelon has started a garden and bee farm. After seeing how many bees were showing up to his vegetable and fruit garden, he contacted the Toronto Beekeepers Co-Operative to add hives to the hotel roof ${ }^{7}$. The first year produced $150 \mathrm{~kg}$ of honey by the autumn season, which doubled in numbers by $2009^{\circ}$. The honey, as well as the vegetables and fruit grown on the 14th floor of the hotel, is used in the several restaurants at the hotel. A Forbes special report released in 2010: "2020: What Happens Next" predicted that $20 \%$ of all food consumed in US cities will come from rooftop and parking lot farms by the year $2018^{9}$.

The residents of Toronto have also expressed urgency for a shorter food supply chain. In a Toronto telephone survey conducted by Ipsos-Reid, $79 \%$ of respondents agreed with the statement: "I prefer to buy locally grown fruits, vegetable, and meats." $90 \%$ of respondents also agreed that the distance a food product travels is a concern ${ }^{10}$. Since live food such as animals, fruits, and vegetables have been part of the urban context until very recently, there is uncertainty about food that now appears out of trucks, planes, and ships. Communities in Toronto have begun to fight for the return of food production within the city. Like many other cities in North America, Toronto is wrestling with the decision to change its bylaws in order to allow small broods of chickens in residential backyards ${ }^{11}$. Farmers markets have also been appearing in most of the major neighbourhoods within 


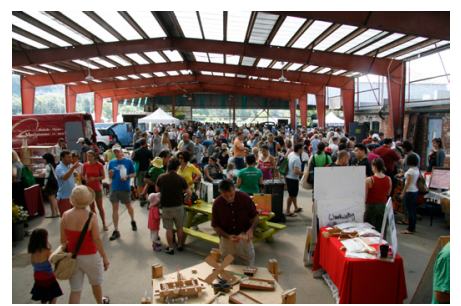

Image 12. The Evergreen Brickworks Farmer's Market. The market was converted from Toronto's brickyards built in 1889. the city. Some examples include the Evergreen Brick Works Farmer's Market on Bayview Ave., Junction Famers' Market on Dundas St. W., Regent Park Farmers Market on Dundas St. E., and Nathan Phillips Square in front of City Hall on Queen St. W. As demand for a direct connection from farm to table increases, Toronto's number of farmer's market will continue to grow.

Cities, especially financial centres like Toronto, are hubs for niche and specialized markets ${ }^{12}$. Profitable urban farmers depend on dedicated customers, farmers markets, and restaurants to sell their high value products. Consumers within the urban context are more concentrated and plentiful than outside city boundaries. Local produce that suggests a more healthy and fresh product has become an important mechanism to justify higher prices ${ }^{13}$. Restaurant menus and store signage are advertising the source of their food to promote their involvement in the local food movement. This thesis project uses this high demand of local food to propose a marketplace design that will sell local produce to the growing numbers of niche consumers. A driving factor for this growing demand is the constant media attention reiterating the public's suspicion for industrialized food. Well-noted documentaries such as 'Food Inc.' by Robert Kenner and popular books such as 'Salt, Sugar, Fat' by Michael Moss have also become popular on the mainstream North American market. In the United States sales of locally grown foods were worth $\$ 4$ billion in $2002^{14}$. As media continues to promote attention to local food movements, the local food economy will continue to grow. 


\subsection{Toronto and the New Food Movement}

In 1976, Canada signed the United Nations Covenant on Social, Economic and Cultural Rights which included the component "the fundamental right of everyone to be free from hunger 15 . Toronto, has continually been a leader for urban food initiatives. In 1996 Hunger Watch was formed by a group of food activists from the city council. The Food and Hunger Action Committee (FAHAC) was formed in 2001 to develop the first multi-sectoral food security plan. Toronto's Food Charter achieved policy commitments from the City Council in May 2000. Developed in the 1980s its original aim focused on emergency food services ${ }^{16}$. Since then its focus has broadened to include the right to food in a democratic society, criticizing the current global food model and promoting local initiatives.

Toronto's Food Policy Council (TFPC) is the only food policy council in NorthAmerica that is its own government department, rather than an advisory board. It was created in 1990 with the objective of finding long-term solutions for problems within the food system including sustainability and hunger ${ }^{17}$. Since its inception it has funded many programs such as the GrowTO Urban Agriculture Action Plan and the Toronto Youth Food Policy Council (TYFPC) $)^{18}$. The most recent plan, "Grow TO: An Urban Agriculture Action Plan for Toronto" was released in October $2012^{19}$. It focuses on urban agriculture within the city such as community gardens, greenhouses, rooftop farms, and urban livestock. It also mentions the use of greenery to filter pollution in the air by taking in carbon dioxide and releasing oxygen. Hundreds of projects and network creations within the city have been directly endorsed by the Toronto Food Policy Council such as the West End Food Co-op and the Toronto Urban Growers.

Toronto's food movement is a web of networks consisting of community agencies, municipal agencies, regional movements, advocacy groups, educations projects, government staff, and policy makers. Foodshare is a non-profit organization based in Toronto. It focuses on the accessibility of nutritious food for neighbourhoods, regions, cities, and the nation ${ }^{20}$. They run programs such as Field to Table, which assists farmers by connecting them to new markets. 
Section 3 :

The New Food Movement

Another well known program is the Good Food Box, which provides low incomes families with fresh produce directly from the Ontario Food Terminal. It is within the context of Toronto's leadership in the food movement that the design project for this thesis was inspired. The architectural design is a realization of the core values and policies of the city's leading local food organizations. 
Section 3 :

The New Food Movement

\section{Section 3 Endnotes}

1. Cormier, Brendan "A Pressure Cooker Simmers on the Back Burner." in The Edible City: Toronto's Food from Farm to Fork, edited by Christina Palassio and Alana Wilcox, 284. Toronto: Coach House, 2009.

2. "Local Food Chains" Canadian Food Inspection Agency. Accessed March 31, 2014.

$<$ http://www.inspection.gc.ca/food/labelling/food-labelling-for-industry/local-food-claims/ eng/1368135927256/1368136146333>

3. Cockrall-King 2012, 77

4. "Local Food" Livegreen Toronto. Accessed March 31, 2014. <http://www.toronto.ca/livegreen/greenlife localfood.htm>

5. Taylor, Lisa. Your Farm in the City: An Urban Dweller's Guide to Growing Food and Raising Livestock. New York: Black Dog \& Leventhal, 2011.

6. Cockrall-King 2012,17

7. Verge, Stephanie. "The Love(ly) Bug: An Ode to Bees in the Era of Colony Collapse Disorder, Wasp Invasion and Rooftop Apiaries." in The Edible City: Toronto's Food from Farm to Fork, edited

8. Verge 2009, 134-139 by Christina Palassio and Alana Wilcox, 134-139. Toronto: Coach House, 2009.

9. james, Scott. "The Future of Food" Forbes. Last modified September 28, 2010. <http://www.forbes.com/sites/csr/2010/09/28/the-future-of-food/>

10. Ladner 2011, 23

11. Cockrall-King 2012, 215

12. Ladner 2011,85

13. Ladner 2011,85

14. Halweil, Brian. "Worldwatch Paper \#163: Home Grown: The Case For Local Food In A Global Market." Worldwatch Institute. Accessed January 19, 2014. <http://www.worldwatch.org/node/827>

15. Wekerle, Gerda R. "Food Justice Movements: Policy, Planning, and Networks." Journal of Planning Education and Research 23 (2004): 378-386. Accessed July 31, 2013. doi:

6. Wekerle 2004 $10.1177 / 0739456 \times 04264886$

17. Wekerle 2004

18. "About" Toronto Food Policy Council. Accessed March 31, 2014 $<$ http://tfpc.to/about>

19. "Grow TO: An Urban Agriculture Action Plan for Toronto (2012)." Toronto Food Policy Council, Oct, 2012 Accessed Sept 16, 2013 <http://tfpc.to/wordpress/wp-content/uploads/2012/08/GrowTO ActionPlan_Oct161.pdf>

20. "Food Policy." Foodshare Toronto. Accessed January 21, 2014. $<$ http://www.foodshare.net/food-policy>. 


\section{Section 4 :}

\section{Systems}

"Everyone knows the two statements that answer our question. One says: Technology is a means to an end. The other says: technology is a human activity. The definitions of technology belong together ${ }^{1} . "$

- Martin Heidegger

(German philosopher and writer) 


\subsection{Technological Development}

Many new technologies have been developed to assist with indoor food production. The most common are systems such as hydroponics, aquaponics, and aeroponics. These systems act as supplements and not replacements for conventional farming ${ }^{2}$. Conventional farming is more practical for large-scale cereal crops such as rice, wheat, and corn. However, hydroponic technology has the potential to increase crop yield by 20 times the size while using 30 times less water than conventional outdoor growing for other commercially available produce ${ }^{3}$. Currently, many commercial greenhouses, as well as private residents, have begun to take advantage of this year-round technology. Additional development in LED* lighting technology has allowed for the supplementation of natural sunlight during clouded days improving and controlling indoor growing conditions ${ }^{4}$. 


\subsection{Hydroponics}

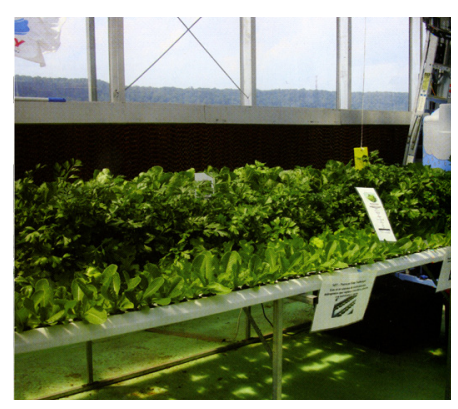

Image 13. A hydroponic system made of PVC piping
In 1937, St. William Frederick Gericke began development of greenhouse-based hydroponic agriculture at the University of California ${ }^{5}$. Hecoined thename "hydroponics", which comesfrom the greek word "hydros" meaning water, and "ponos" meaning labour". It has been calculated that an average family's fresh vegetable needs could be met by a 50 square foot indoor hydroponic garden.

Over the last 15 years, a large number of commercial hydroponically grown crops have found their way into supermarkets such as tomatoes, cucumbers, herbs, strawberries, and peppers ${ }^{7}$. Hydroponic systems grow plants such as flowers, fruits, and vegetables in nutrient rich water without the need for soil ${ }^{8}$. The most familiar example of this process is highlighted by the avocado seed due to its ability to grow to near maturity from a seed in a glass of tap water and sunlight ${ }^{9}$. The same process has been commercially applied to many other plants. Most nurseries begin the process by coaxing seeds to germinate and sprout roots which are placed into the piping of a hydroponic system ${ }^{10}$. Nutrients are dissolved into the water which circulates through the pipes ${ }^{11}$. Electronic monitors connected to the hydroponic system monitor nutrient levels including organic nitrogen, which results in uniform plant growth under optimal conditions ${ }^{12}$. The advantages of hydroponic systems include water conservations, pest control, and freedom from outdoor weather conditions ${ }^{13}$. 


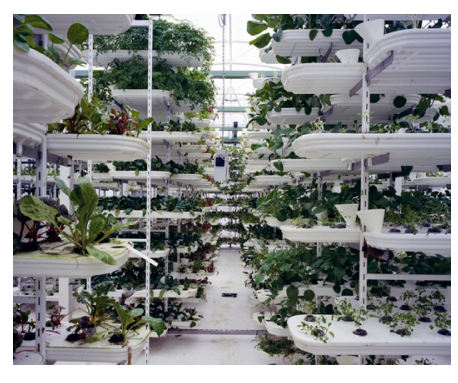

Image 14. Paignton Zoo grows 112 lettuces per square meter
An advanced and popularly used hydroponic system is the Nutrient Film Technique (NFT), which offers the advantage of being a lighter weight structure. It has an advantage on rooftops because the water is stored in a reservoir that is placed on a more structurally sound location of the roof ${ }^{14}$.

Paignton Zoo in Devon, UK uses hydroponics in its operation for feeding its animals and visitors. The system includes a greenhouse with 11,000 plants of lettuce, spinach, chicory, chard and herbs that grow in stacked hydroponic trays ${ }^{15}$. The water and nutrient runoff from the feeding stations is captured and recycled which allows them to use only $5 \%$ of the water compared to conventional farming techniques ${ }^{16}$.

Hydroponics will be applied to the design of the proposed farming tower because it will allow maximization of square footage within the structure. Hydroponic systems are lightweight and will be supported by the structural system. Furthermore, the different variations and flexible design of the systems will suit the urban context of the Distillery District where conventional farming will not be possible. 


\subsection{Aquaponics}

${ }^{*}$ Aquaculture: Fish farming

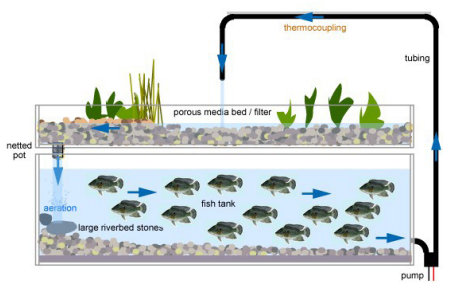

Image 15. Aquaponics Diagram
Aquaponics is a combination of aquaculture* and hydroponic elements to create a system that cleans and fertilizes itself in the production of horticulture ${ }^{17}$. Aquaponics systems mimic the natural environment of ponds and lakes in a monitored indoor setting. Fish are grown in tanks of water in which the roots of plants are immersed. The waste from the fish is filtered by these plants, and in turn the ammonia-rich nutrients from the waste fertilize the plants ${ }^{18}$. This produces growth for the crops as well as a natural water filtration system for the fish tank. It is estimated that the crops require $80-90 \%$ less water than crops grown through conventional farming practices ${ }^{19}$. The appeal of an aquaponics system is that the closed loop cycle does not require any input other than fish food. Aquaponic systems produce vegetables and herbs for consumption and the fish can be eaten as well. Aquaponics UK, a social enterprise that launches aquaponics projects worldwide, estimates that 5 pounds of fish food can produce 100 pounds of vegetables and 2 pounds of fish ${ }^{20}$. Currently, Toronto has two aquaponics farms, both located in high schools as a source of education. Toronto's first large scale aquaponics farm is currently being built in a Downsview Park greenhouse in early 201421. It is expected to contain an 1800 square foot system that will grow and sell vegetables for profit. There are many successful examples of aquaponic systems in North America. AquaRanch Industries in Flanagan, Illinois started in 1992 and currently uses a 12,400 square foot warehouse to produce crops $^{22}$. They use tilapia to grow organic lettuce, kale, chard, herbs, tomatoes, and hot peppers. 


\subsection{Aeroponics}

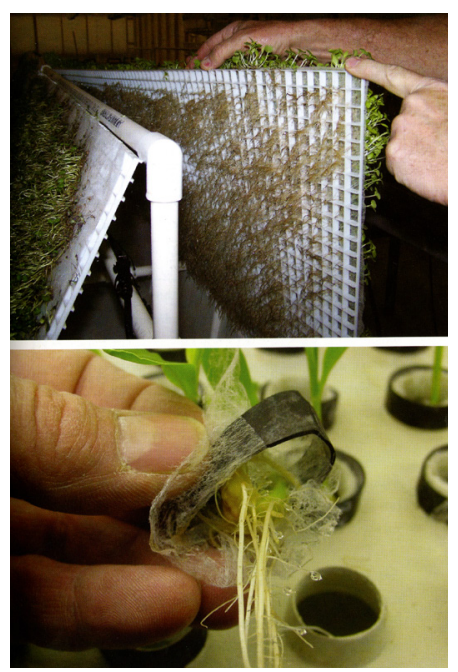

Image 16. Aeroponics system
Aeroponics is a form of soilless growing where roots are merely misted with nutrient rich water ${ }^{23}$. Invented by Richard Stone in 1982, aeroponics systems features small nozzles situated under the plants. The nozzles supply the roots with all the nutrients, hydration, and oxygen required by the plants ${ }^{24}$. Though many consider aeroponics to be a type of hydroponic system, the main difference is that aeroponic systems do not use a growing medium $^{25}$. Aeroponics consumes $70 \%$ less fresh water than hydroponic systems because it is recirculated in a closed loop cycle, which makes the systems lighter and more resource friendly.

Two graduates of Humber College's Sustainable Energy and Building Technology Program Jake Harding and Gustavo Macias started Skyline Farms in Toronto ${ }^{26}$. The aim of Skyline Farms is to reclaim under-utilized urban spaces to grow certified organic heirloom seeds with the use of aeroponic technology. The pilot project was launched in June 2013, in partnership with Mr Food, My Way, Toronto District School Board (TDSB), and Toronto Education Workers (TEW) ${ }^{27}$. A vertical aeroponic Tower Garden farm was set up at Thistletown Collegiate Institute in Etobicoke, allowing students to participate in the growth, harvest, and consumption of the crop ${ }^{28}$. 


\section{Systems}

\section{Section 4 Endnotes}

1. Heidegger, 1954 2. Despommier 2010, 71

3. Ladner 2011, 64

4. Ladner 2011, 63

5. Despommier 2010, 163

6. "FarmedHere: The Freshest, Healthiest and the Most Local Greens in Chicago." FarmedHere. Accessed February 4, 2014.

<http://farmedhere.com/\#products>

7. Despommier 2010, 7

8. Cockrall-King 2012, 265

9. Despommier 2010, 163

10. Despommier 2010, 163

11. Despommier 2010, 165

12. Despommier 2010,165

13. Ladner 2011,80

14. Ladner 2011, 67

15. Ladner 2011, 65

16. Ladner 2011, 65

17. Cockrall-King 2012, 265

18. Ladner 2011, 72-73

19. Ladner 2011, $72-73$

20. "Aquaponics UK." Aquaponics UK. Accessed January 22, 2014 $<$ http://www.aquaponics.org.uk/>

21. "Canadian Aquaponics - Canada's Source For Aquaponic Information and News." Coming Soon: Toronto's First Commercial Aquaponic Farm. Accessed January 22, 2014 <http://www.canadianaquaponics.com/2014/01/coming-soon-torontos-first-commercial.html>.

22. "AquaRanch - Systems, Tilapia, Produce, and Basil Vinaigrettes." AquaRanch- Systems, Tilapia, Pro duce, and Basil Vinaigrettes. Accessed January 22, 2014. $<$ http://www.aquaranch.com/index.html>.

23. Cockrall-King 2012, 265

24. "FarmedHere: The Freshest, Healthiest and the Most Local Greens in Chicago." FarmedHere. Accessed February 4, 2014.

<http://farmedhere.com/\#products>

25. "Aeroponics, Aeroponic Gardening, Hydroponics." Tower Garden. Accessed February 4, 2014 <https://www.towergarden.ca/what-is-tower-garden/how-it-works/aeroponics>

26. "About Skyline Farms." Skyline Farms. Accessed February 4, 2014.

<http://skylinefarms.ca/index.php/about>

27. "About Skyline Farms." Skyline Farms.

28."About Skyline Farms." Skyline Farms. 


\section{Section 5 : The Vertical Farm}

"If the skyscraper farm is like a 747 jetliner, we are now at the stage of the Wright Brothers. All kinds of urban microagribusinesses are bursting onto the scene in cities across

America, and in other countries around the world. There will be many failures as a legion of tinkerers and engineers all struggle to take off with the right combination of profitability, sustainability, and quality food ${ }^{1} . "$

- Major Carter

(President of Majora Carter Group, LLC) 
Section 5 :

\subsection{Despommier and the Vertical Farm}

The term 'Vertical farming' was first coined by American geologist Gilbert Ellis Bailey and used as the title of his book published in 1915. In his book, he explored some of the contemporary standards in which society now considers vertical farming. Some of these ideas included the benefits of year round production, food close to population centres, and reduced water waste though he did not yet have a scientific solution to achieving these concepts.

In 1999, Dr. Dickson Despommier began his vertical farming project during one of his medical ecology courses at Columbia University.. Despommier first proposed the idea of the vertical farm as a solution for feeding a growing urban population worldwide and freeing up farmland so that it can eventually cycle back to its natural state ${ }^{2}$. The advantages of a vertical farm, as outlined by his book "The Vertical Farm: Feeding the World in the 21st Century", include year round crop production, elimination of weather related crop failures, allowance for ecosystem restoration, and no agricultural runoff $^{3}$. Tackling one of the main concerns of current agricultural practices, chemicals such as fertilizers and pesticides will be eliminated with the use of hydroponic systems within the vertical farm. 


\subsection{Epcot, Disneyworld}

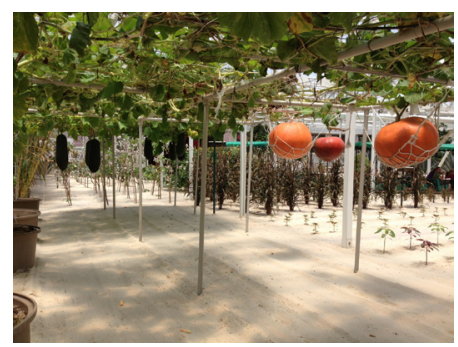

Image 17. Hydroponics in The Lan d Pavilion in Epcot, Disneyworld
At Walt Disney World's Epcot theme park in Orlando, Florida, six acres are covered by a set of glass domes that encompass its largestattraction: "The Land". Inside the glass domes are greenhouses that produce crops in hydroponic systems which are tended by Disney's horticulturalists. A variety of hydroponics are used, depending on the plant that is being grown, such as aeroponics, bag culture, the nutrient film technique, and sand culture $^{4}$. Plants including herbs, brussel sprouts, okra, cabbage, kale, bok choi, and edible flowers are grown in the aeroponic systems designed and named by the horticulturalists as "column pots". Pots are attached to large hollow pipes in which the plant roots sit and are periodically misted with nutrient solution. Bag culture using Rockwool, perlite, or coconut coir bags are the most common commercially used hydroponic systems, and are used in The Land for crops such as cucumbers, tomatoes, peppers, and eggplant ${ }^{5}$. According to Les Frey, a Disney horticulturalist, the sand cultured plants at Epcot show "how plants can be grown in sand or desert regions of the world using hydroponics. The nutrient water is supplied to the plants using the subsurface drip irrigation. It is used in some places around the world, but is not very common ${ }^{6}$." For this reason nearly 45 crops, including all the crops the temperate and tropics greenhouses such as pummelo and cotton are grown using sand culture. Aquaponic systems are also incorporated and being explored within "The Land" operations as well. 


\subsection{FarmedHere}

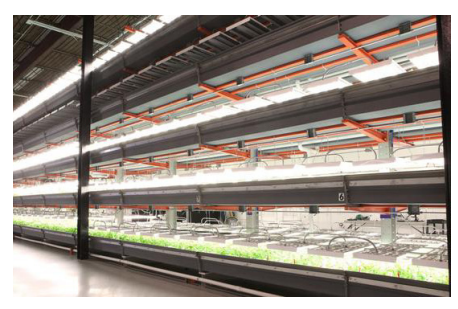

Image 18. Vertical layers of crops inside the FarmedHere facility
FarmedHere is a sustainable indoor farming company that runs the largest vertical farm in Chicago. It currently occupies a fifth of a 90,000 square foot warehouse in Bedford Height, which accommodates crops grown in hydroponic systems ${ }^{7}$. The systems are stacked in vertical layers of trays and lamps that almost reach the 24 foot high ceiling. A combination of aeroponic and aquapponic systems are used with fluorescent lights as the facility is solely dependent on electrical lighting. Aeroponics was chosen to reduce weight and to accelerate growth of arugula plants while tilapia fish in aquaponic systems are used for their four varieties of basil ${ }^{8}$. The company claims to reuse $97 \%$ of fresh water, along with no use of herbicides, nor any pesticides ${ }^{9}$. The farmers are at-risk youth that are trained by a local non-profit organization who manoeuvre the facility on moving platforms. FarmedHere also uses over $90 \%$ less plastic compared to the traditional boxes in the supermarkets with their green paper packaging ${ }^{10}$. Its arugula sells for $50-75$ cents more in comparison to imported organic arugula but continues to sell out fast, building a loyal market from local consumers in Chicago ${ }^{11}$. 


\subsection{Suwon, Korea}

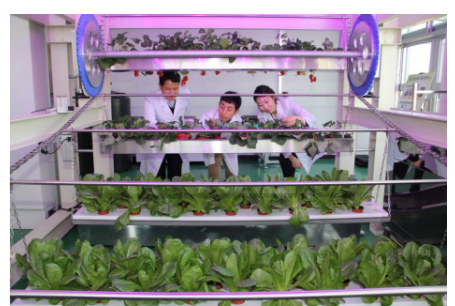

Image 19. Scientists develop LED and hydroponic systems in Suwon, kroea
The city of Suwon, South Korea is the location for a three story vertical farm prototype structure since the year 2009. Solar panels sit on the roof for power but the facade of the building is not made of glass for natural light penetration because LED lights are used for the growth process. Heads of lettuce are grown in stacked trays in a strictly monitored environment in which light, temperature, and the wavelengths of LED light are consistently regulated ${ }^{12}$. Each person that enters the vertical farm must also pass through an air shower to prevent exterior bacteria from infecting the crops indoors. The lettuce that the vertical farm is currently producing uses no pesticides between the sowing and harvest periods, as well as using recycled water ${ }^{13}$. The end goal for such strict management is to find the most optimal cultivation conditions in which the lettuce can grow in order to compete with the commercial market in the future. Scientists and researchers at the facility believe that the vertical farm will be ready for the free market by the year $2016^{14}$. 


\subsection{The Design Project}

The example of The Land pavilion at Epcot not only demonstrates a successful model of large scale hydroponics for commercial use, but shows that the design of the hydroponic systems can be customized to each different crop. For example, melons are grown in taller structures designed to support the vines as the fruits mature and hang, while lettuce is grown in multi-layer pots that stack above one another. Epcot's innovation in hydroponic design will launch inspiration for the hydroponics within the design project. LED light technology, such as those used in Suwon, Korea can be applied to the hydroponics design in order to supplement for the lack of natural sun light during the winter season in Toronto. The combination of natural and LED light will maximize the crops' ability to grow as well as minimizing crop cycle time.

Toronto can be considered a comparable city to Chicago, both being the largest food processors in North America as well as having a similar population. FarmedHere's success in the commercial marketplace may very well indicate the level of profitability that a vertical farm in Toronto can achieve. Niche markets for hydroponics and organic produce have gained much influence in large cities such as Toronto and Chicago, which the project's market design capitalizes on. 


\section{Section 5 Endnotes}

1. Despommier 2010, xv

2. Despommier 2010, 145

3. Despommier 2010, 151

4. "Here at Epcot They Are Using Various Hydroponics Systems to Help Change the World: Part III : The

Land." ThePhotoGardenBee RSS. Last modified January 5, 2010.
<http://thephotogardenbee.com/2010/01/05/aeroponics-gardens-at-epcot-part-iii-the-land/> 5. "Here at Epcot They Are Using Various Hydroponics Systems to Help Change the World: Part III : The Land." ThePhotoGardenBee RSS.

6. "Here at Epcot They Are Using Various Hydroponics Systems to Help Change the World: Part III : The Land." ThePhotoGardenBee RSS.

7. Fairley, Peter. "Urban Agriculture Grows Up." Architectural Record July 2013.

8. "Urban Agriculture Grows Up." Architectural Record

9. "FarmedHere: The Freshest, Healthiest and the Most Local Greens in Chicago." FarmedHere. Accessed February 4, 2014

$<$ http://farmedhere.com/\#products >

10. FarmedHere: The Freshest, Healthiest and the Most Local Greens in Chicago." FarmedHere

11. "Urban Agriculture Grows Up." Architectural Record

12. Kretschmer, Fabian, and Malte E. Kollenberg. "Vertical Farming: Can Urban Agriculture Feed a Hungry World?" SPIEGEL ONLINE. Last modified July 22, 2011.

$<$ http://www.spiegel.de/international/zeitgeist/vertical-farming-can-urban-agriculture-feed-ahungry-world-a-775754.html>

13. "Vertical Farming: Can Urban Agriculture Feed a Hungry World?" SPIEGEL ONLINE.

14. "Vertical Farming: Can Urban Agriculture Feed a Hungry World?" SPIEGEL ONLINE. 


\section{Section 6 :}

\section{Design}

"A building revolves around people and is not merely an architectonic shape. Architecture should be closely integrated with its surroundings, with close consideration of its functions and social context."

- Schmidt Hammer Lassen Architects

(Scandinavian Architecture Firm) 


\subsection{Introduction}

In his book, "The Vertical Farm: Feeding the World in the 21st Century", Dr. Dickson Despommier describes themes for vertical building design. These include "maximizing the amount of space devoted to growing crops" and "employing good barrier design for plant protection"2. Despommier also questions whether essential crops such as wheat, rice, potatoes, and barley should be grown indoors in vertical farms. This design project will not contain these crops because the scale, growing methods, and weight of these crops cannot be accommodated within the tower. This thesis recognizes that vertical farms are not replacements for conventional farming but rather supplements to traditional systems. 


\subsection{The Site}

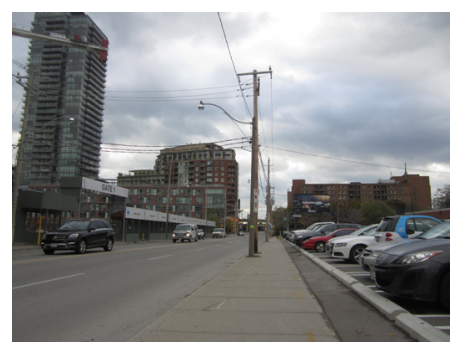

Image 20. North-East corner of the site looking south towards the Distillery District
The site covers the South block on Front Street, between Berkeley St. and Parliament, on the periphery of the Distillery District in Toronto. Since the district has been deemed a National Historic Site of Canada, many of the historic buildings surrounding the site have been adapted and preserved. To the East and West of the block, a number of historical buildings have been converted into commercial retail shops along Berkeley St. and a new police station at the intersection of Front and Parliament. On the South side of the block towards Lake Shore Boulevard East, Parliament Park separates the site from a residential area containing a mid-rise tower and townhouses. The North side of the site along King St. contains commercial shops and services.

Currently, the area is undergoing construction, due to the increased growth and popularity of the Distillery District. At the intersection of Parliament St. and Mill St., on the East side, a new condominium tower is in the early stages of construction. Front St., being a historic main street of York, is being regenerated as well. A Budget Rent-a-Car presently resides on the South block of the site, whereas a Staples Business Depot and a Porsche car dealership occupies the North block. 
Section 6 :

Design

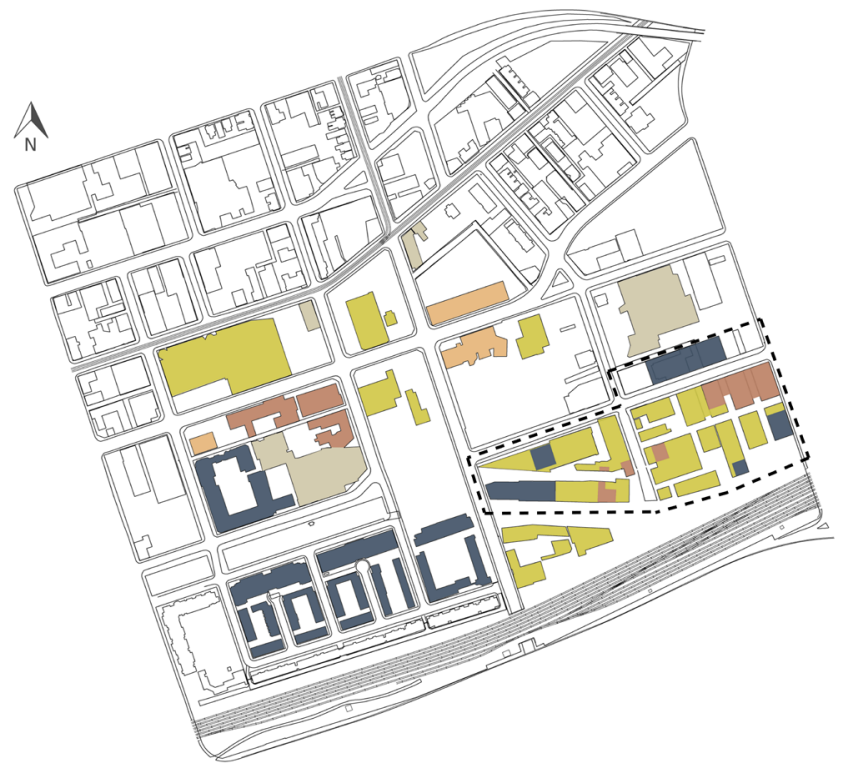

residential

commercial

theatres and galleries

institutional

office

- - - distillery district

Diagram Neighbourhood Programming 
Section 6 :

Design

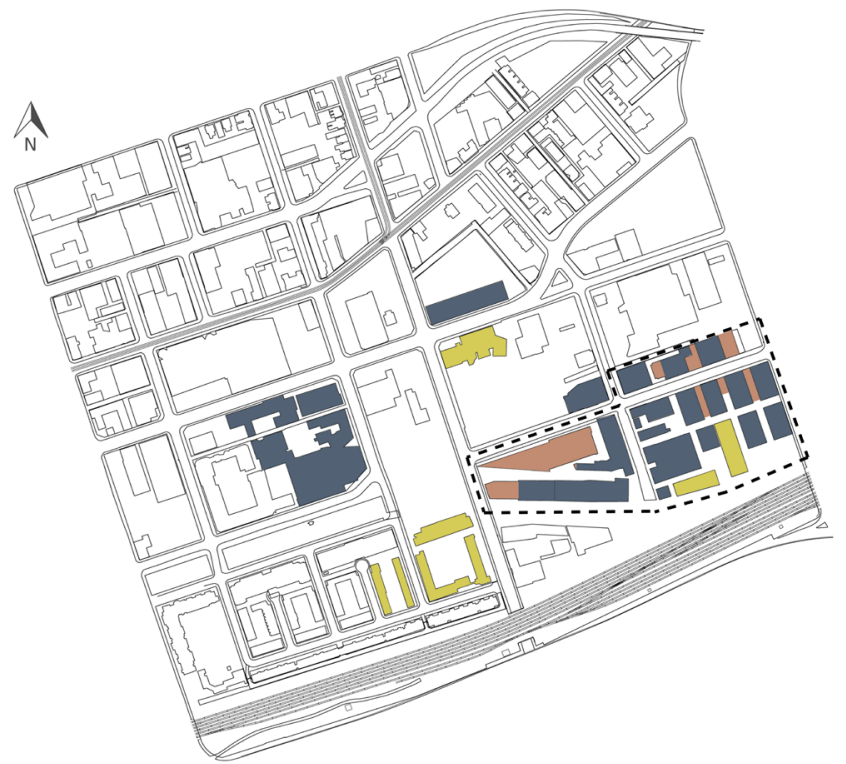


Section 6 :

Design

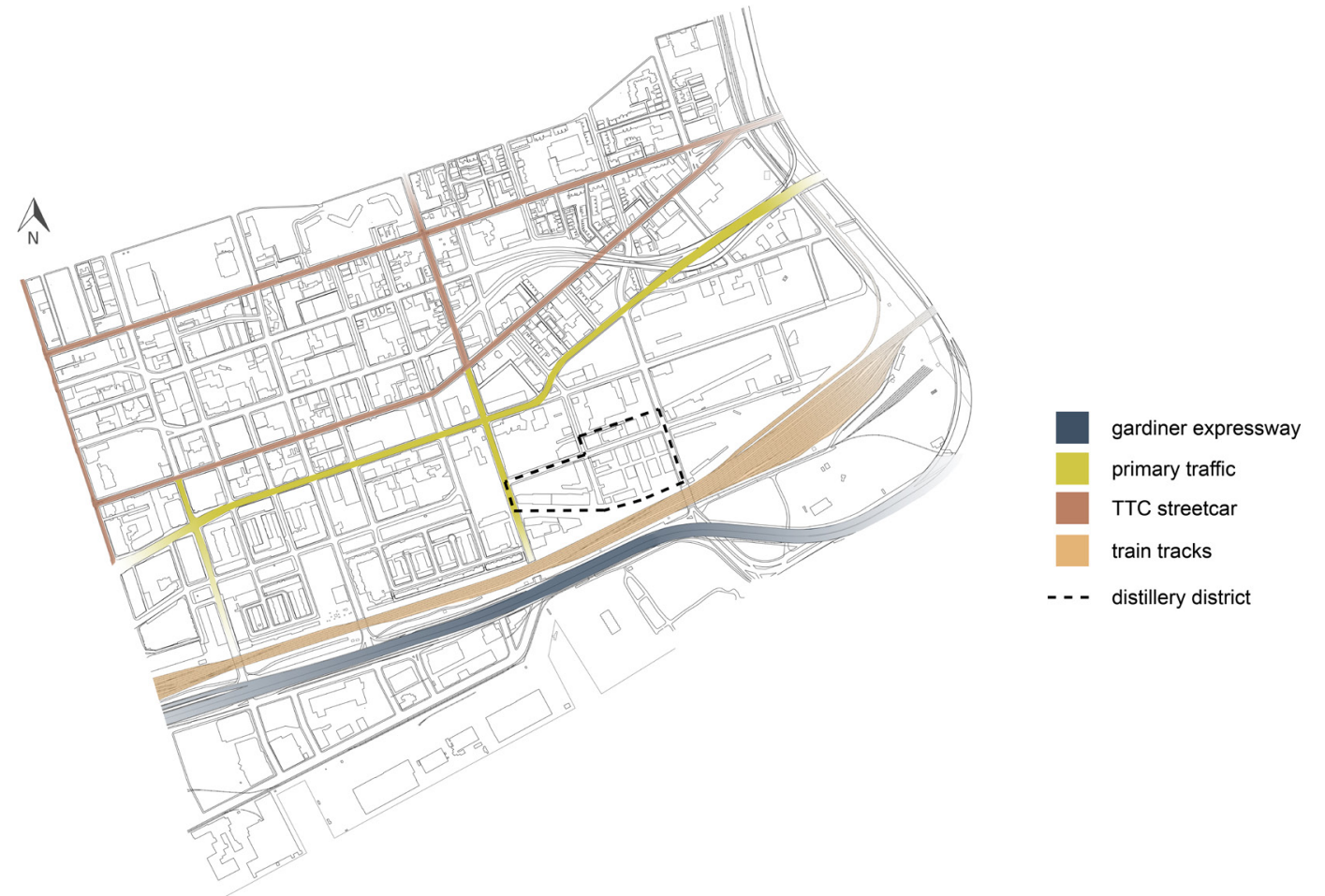

Diagram City Transport 
Section 6 :

Design

Autumn 6 am

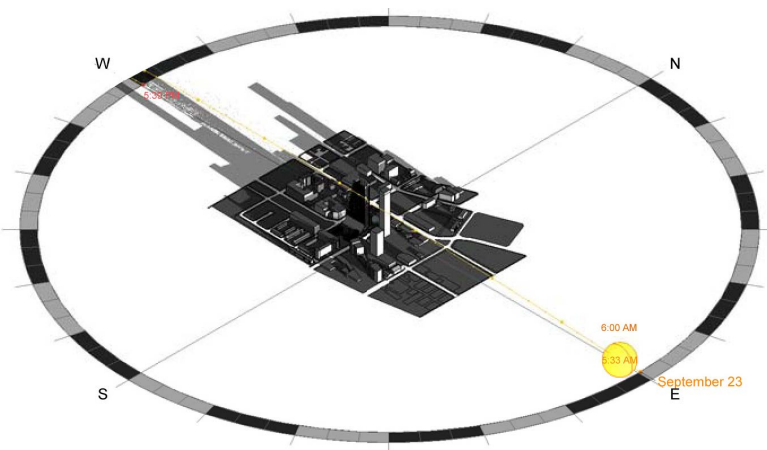

Autumn 10 am

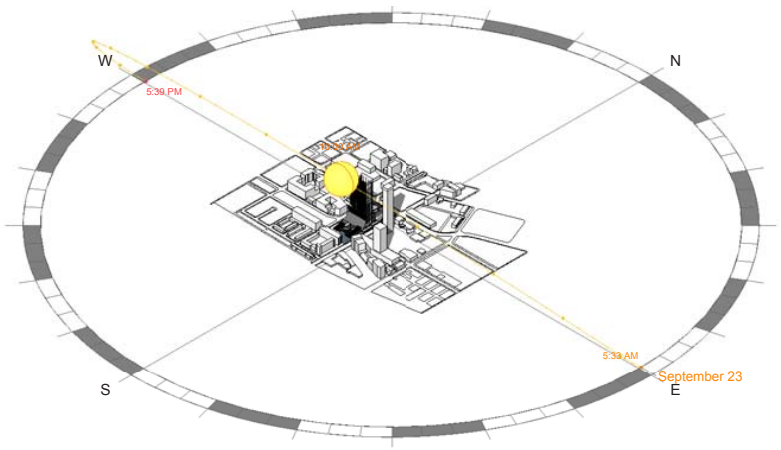

Autumn 2 pm

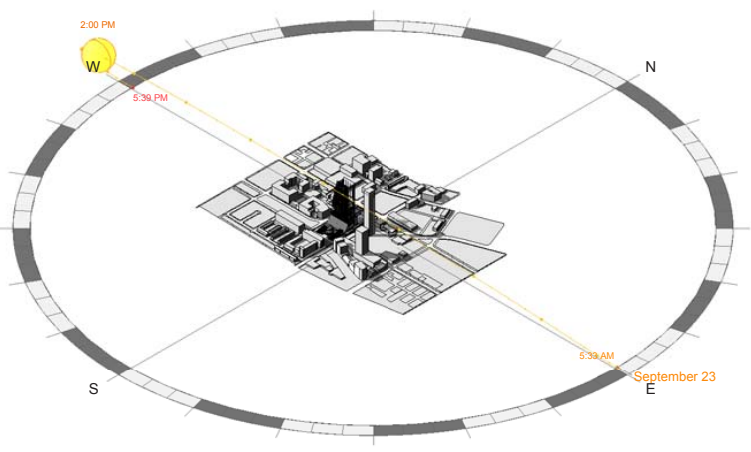

Autumn 6 pm

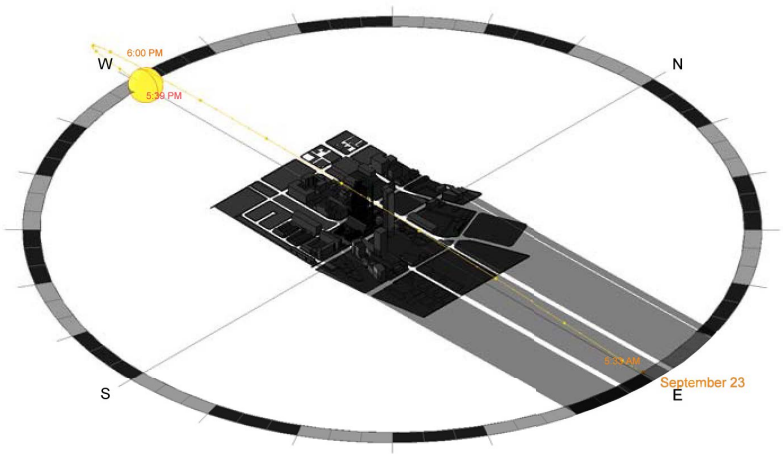

Sun Studies Autumn 
Section 6 :

Design

Winter 6 am

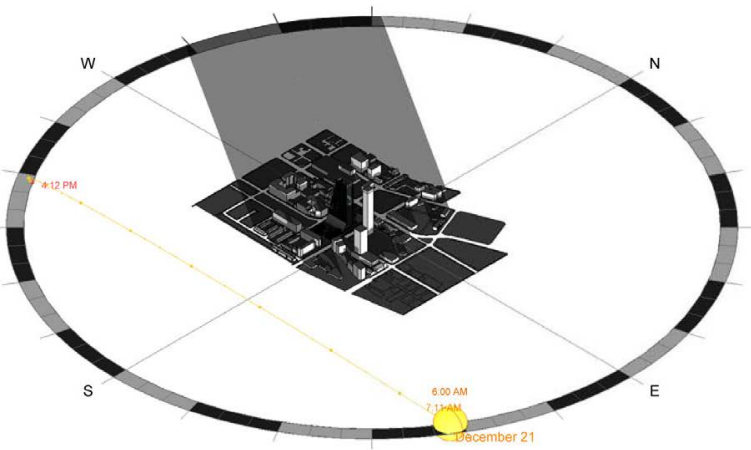

Winter 10 am

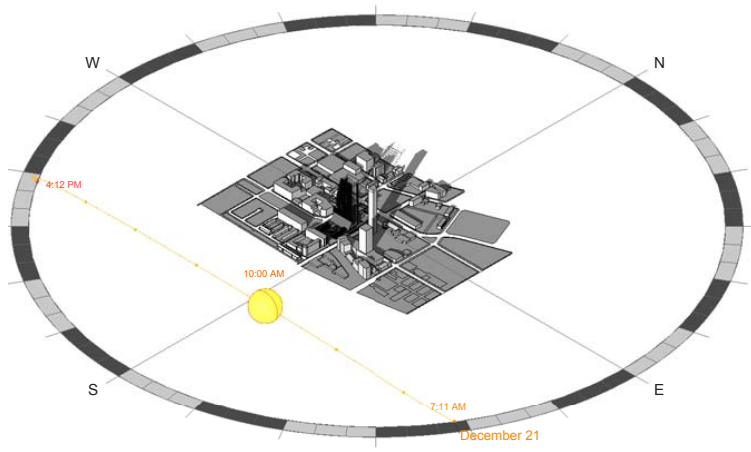

Winter 2 pm

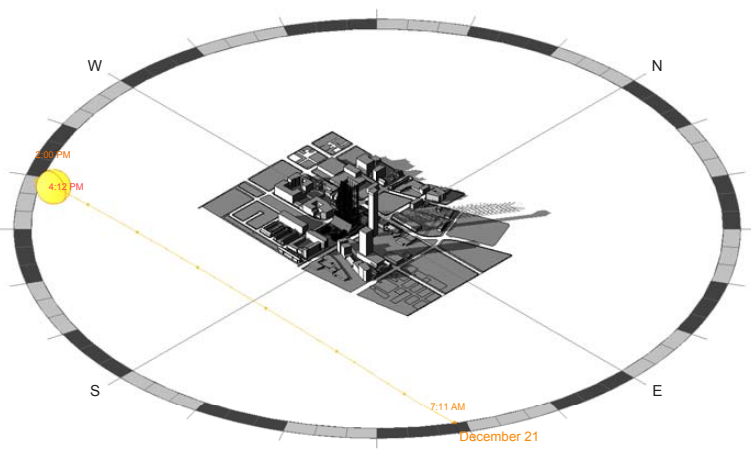

Winter 6 pm

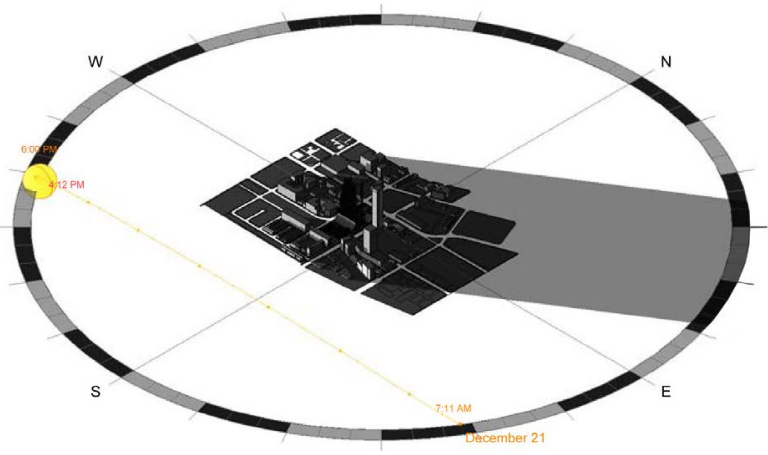

Sun Studies Winter 
Section 6 :

Design

Spring 6 am

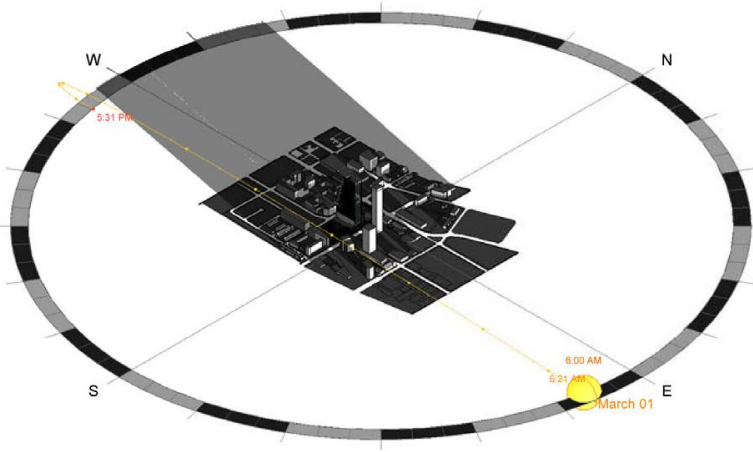

Spring 10 am

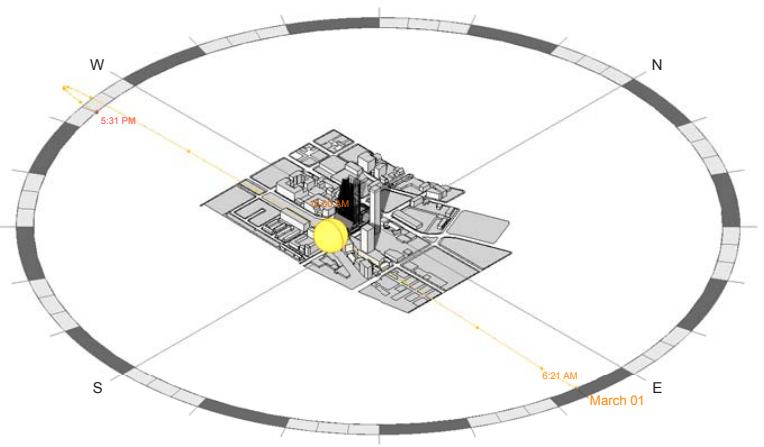

Spring 2 pm

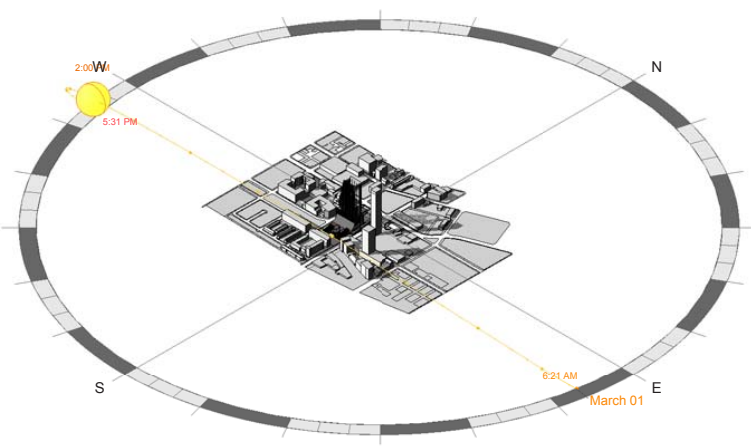

Spring 6 pm

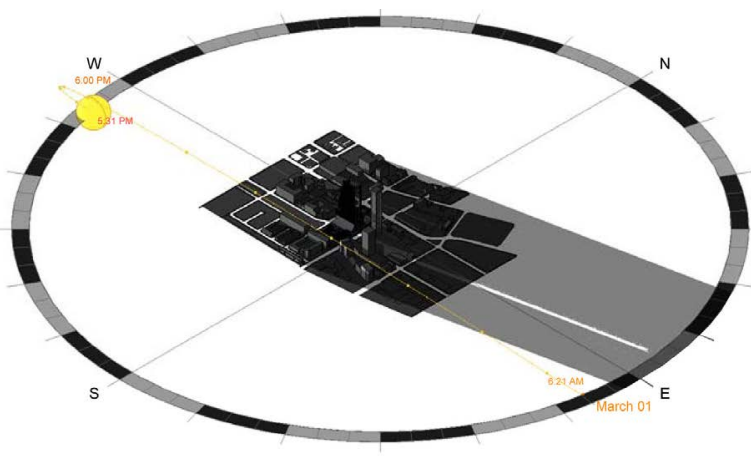

Sun Studies Spring 
Section 6 :

Design

Summer 6 am

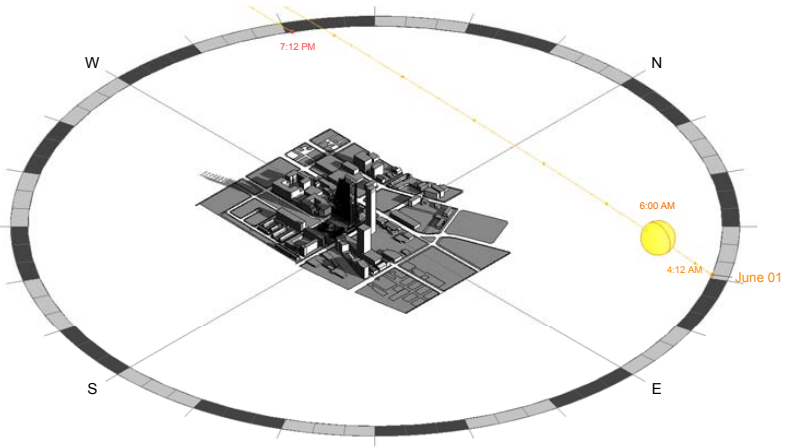

Summer 10 am

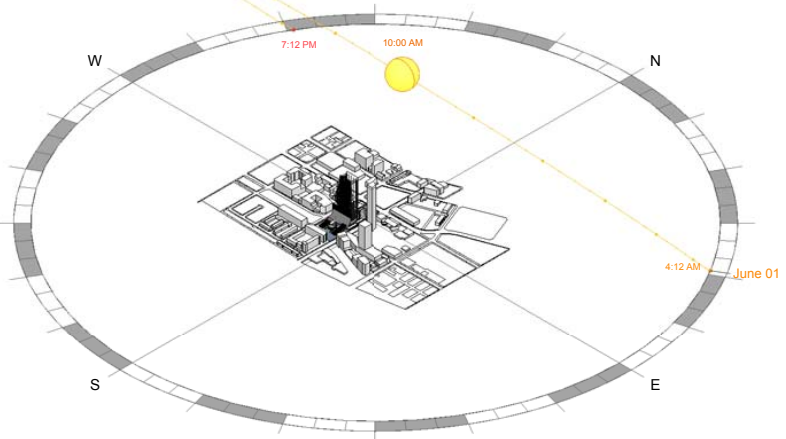

Summer 2 pm

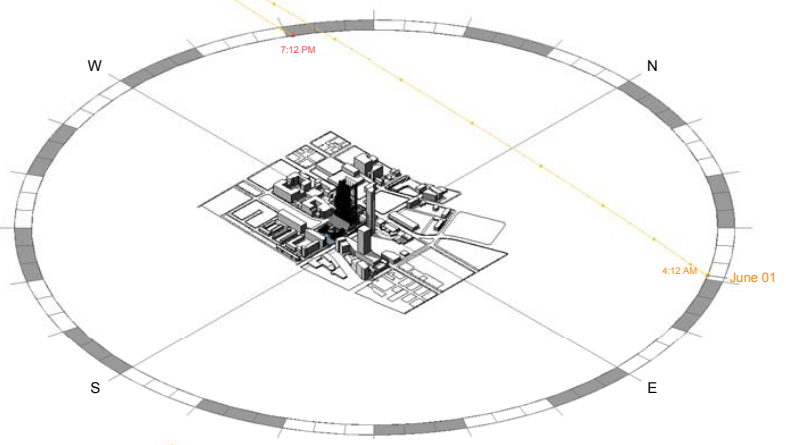

Summer 6 pm

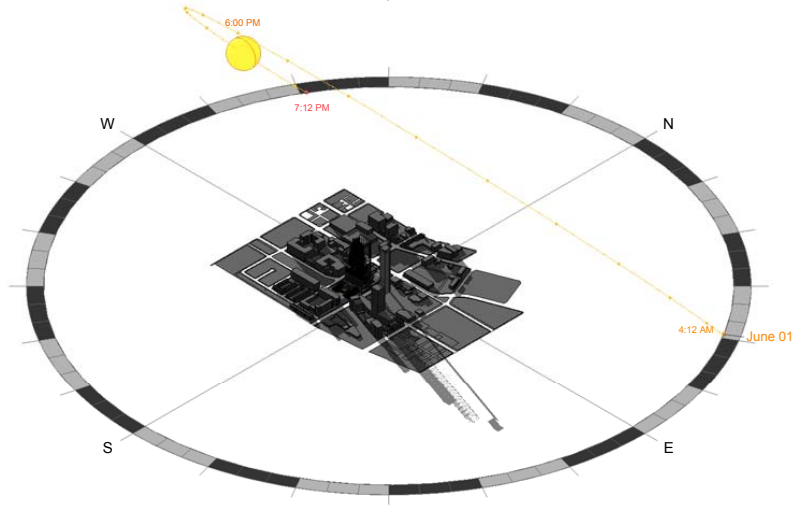

Sun Studies Summer 


\subsection{The Distillery District}

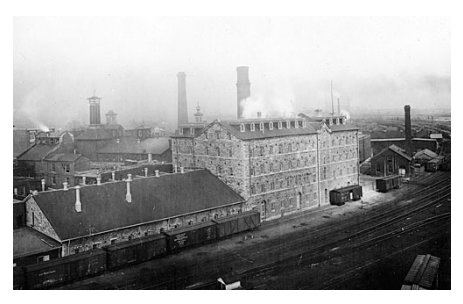

Image 21. The Distillery District in 1918.
Toronto's Distillery District is a recognized national historic site that operates as a mixed-use neighbourhood. The architectural language of the district presently consists of a fusion between Victorian brick industrial buildings dating back to 1859 and new contemporary structures. Though the name "Distillery District" conveys a specific function for the locality, nowadays it is one of Toronto's main tourist attractions that contains a blend of residential, commercial, industrial, and institutional programs. Among these operations are art galleries, retail shops, theatres, restaurants, and cafes.

The evolution of the Distillery District began in 1832 when James Worts and William Gooderham built a grist windmill along the bay of York after emigrating from England in the previous year ${ }^{3}$. Over the years, as the business of Gooderham \& Worts developed into a success, more buildings were built in the neighbourhood and many of the Victorian structures that were built between 1869 and 1895 remain to this day ${ }^{4}$. Most of the structures on the site were designed by David Roberts Sr. and his son David Roberts Jr. ${ }^{5}$.

At the height of the Gooderham \& Worts' success, it was the largest distillery in the world and exported millions of gallons of spirits to South America, New York, and Buenos Aires ${ }^{6}$. During the First World War the distillery converted operations into 


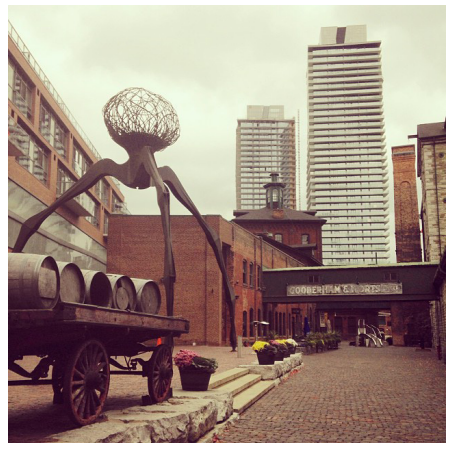

Image 22. Present day Distillery District manufacturing to support the war effort. After the war, Canada's prohibition era brought the production of alcoholic beverages to a halt and business began to decline. The business was purchased by Harry C. Hatch in 1923 and began to produce rum products until 1990 when operations finally cease ${ }^{7}$.

The distillery district reopened in 2003 , as a top tourist attraction in Toronto. Its number of residents has raised considerably since the rebirth of the neighbourhood with the construction of new condominium and commercial development projects. During the summer months, many outdoor events and festivals such as the Toronto Vocal Arts Festival and the Summer Art and Craft Show take place here ${ }^{8}$. 


\subsection{Programming}

The primary program of the project is the vertical farm. Additional programs include a market hall, education centre, public orchard and the public plaza. The public plaza is located along Front St., one of the most important streets running in the east-west direction in Toronto, with landmarks such as the CN Tower and Union Station located along its length. The public plaza sits on the north side of the site and funnels visitors into the market hall, which accommodates vendors and gathering spaces. The market can be accessed through the ground floor facing Front Street, or a ramp travelling from the plaza to the second floor of the market. Both the main entrances from the east and west side of the site are located within the buffer zone between the market hall and the farming tower, creating a journey of reveal when walking under the tower. Towards the centre of the structure, levels of plants climb upwards to form the farming tower, while a central void creates a significant atrium space. On the south side of the site, a small inner courtyard separates the tower and the education centre. A public apple orchard that glides into the facade sits on either side of the education centre.

The plaza along Front St. sets the market hall back from the main road to form a ten meter setback from the street. The plaza offers an outdoor space for the community to gather and interact, with a skating rink during the winter months and abundant bicycle parking for the rest of the year. The size of the plaza can also accommodate an outdoor farmer's market during the warmer months.

The market hall was designed with the intention of providing the neighbourhood with access to the crops grown in the farming tower as well as providing interaction with the hydroponic systems. The ground floor of the market hall accommodates space for shops, vendors, information spaces, and moments of gathering. Above these functions, hydroponic systems float and connect to vendor spaces in order to provide a link between how food is grown to how food is consumed. This not only educates consumers but presents a snapshot of the systems located within the farming tower. The second floor of the market hall 
Design

provides community space for secondary functions related to health such as classrooms, commercial space, and a fitness centre. This second storey is connected to the ground level from the interior as well as the exterior through a ramp linked to the public plaza facing Front St.

The farming tower hovers over the centre of the site with a void through the heart of the floor plates to provide a large atrium space. The first two levels of the tower reveal workers handling the crops grown within the tower and can be viewed by the public. The intention is to provide transparency in the processing of crops. Floors of hydroponic systems are stacked on top of each other on the south, east, and west side of the tower. Offices for the Toronto Food Policy Council and administration for the building sit on the North side of the tower until the 13th floor, above which is a restaurant and garden terrace. The fine dining restaurant sits in the middle of the tower, protruding out of the facade to announce its presence to the exterior. Adjoining the restaurant is an outdoor terrace that services visitors to the restaurant as well as the building and office staff. Structural columns that protrude from the interior of the building are wrapped with vegetation to transform the terrace into a garden during warmer months. The tower is rooted to the ground level through an orchard that glides up its southern facade.

The apple orchard on the south end of the site splits into two strips, nestling the education centre in between its halves. The orchard's path begins on the ground level and flows into glass material above the second level of the structure into the southern facade. This allows patrons of the building to walk underneath and past the tail of the building where the orchard meets the second level terrace. Along the orchard run multiple levels of elevated outdoor space, which provides exterior paths into the second level of the tower and market hall. The orchard provides apples to the public, Canada's top grown and most profitable fruit, and a sense of the functions within the structure.

The building as a whole focuses on the social connection between the farming tower, the community surrounding the site, and the city in which it is located. The design strives to make personal connections between the production of food and the people who consume it, allowing maximum interaction with all parties involved in the process. The orchard was designed as a green space within the urban fabric while the plaza and terraces functioned as pockets of meeting opportunities. 
Design

The tower has glazing on the exterior and interior of its floor plates so as to reveal the intentions of the building. The market was also seen as an opportunity to demonstrate the hydroponic systems that were used in the cultivation of the crops. The circulation designed for the main programs were meant to reinforce an interesting passage of discovery and education. The entrances were not located directly under the tower atrium, but in close proximity in order to create a journey of reveal when walking under the tower. The design not only provided a means for crops to grow within the structure, but also a course for the public to approach and interact with the architecture. 
Section 6 :

Design

DOWNTOWN FOOT TRAFFIC

FRONT ST.

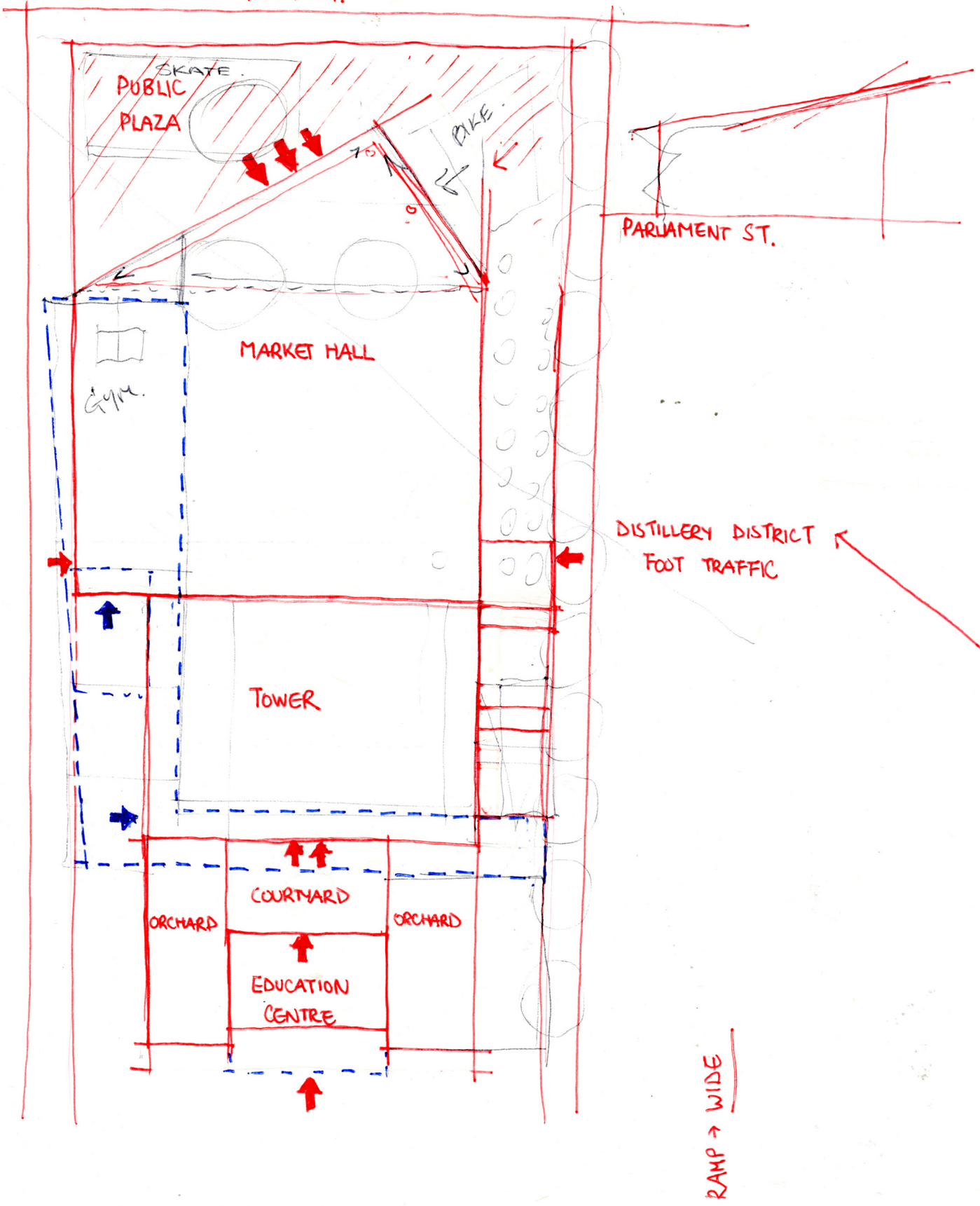

Programming Sketch Plan 
Section 6 :

Design

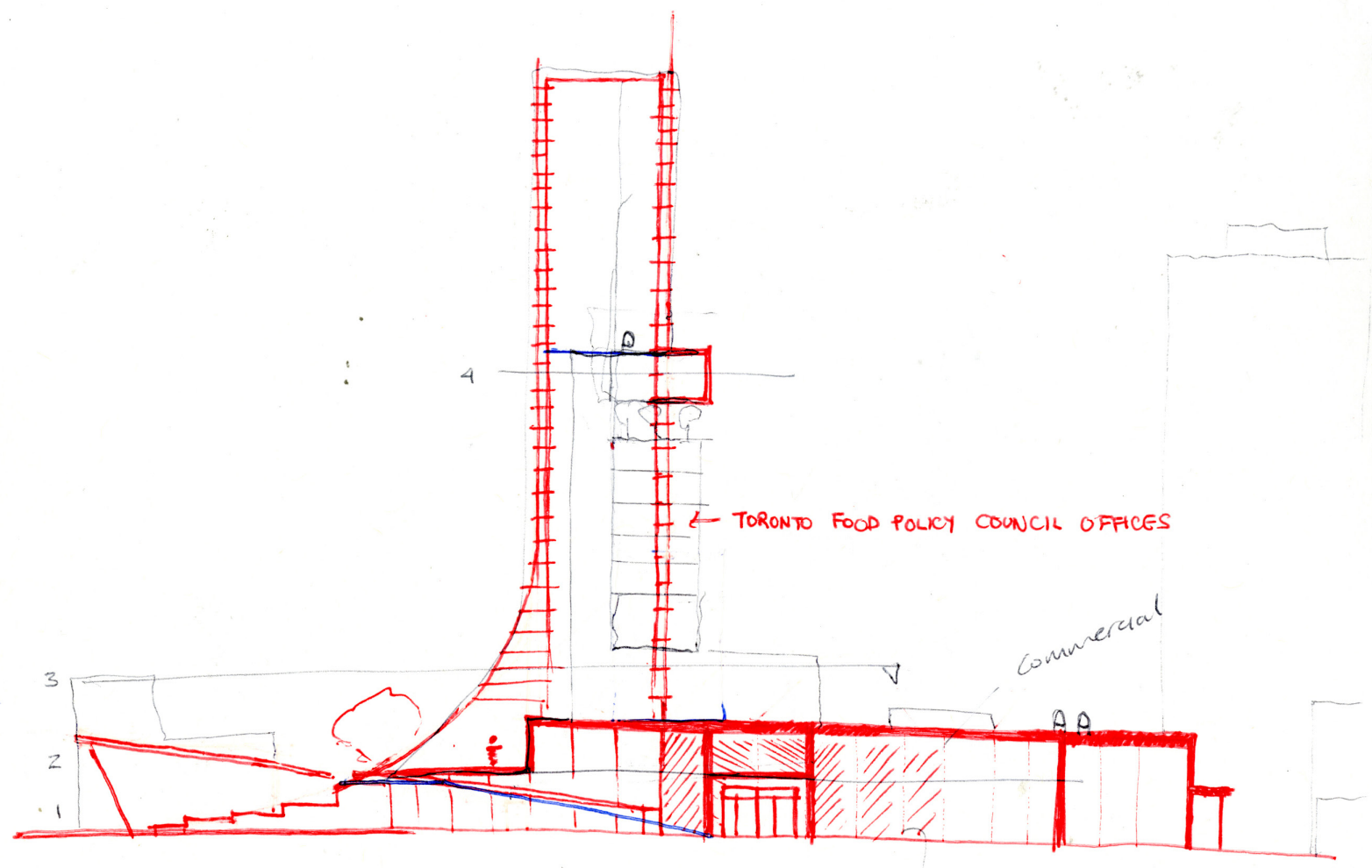

Programming Sketch Section 
Section 6 :

Design

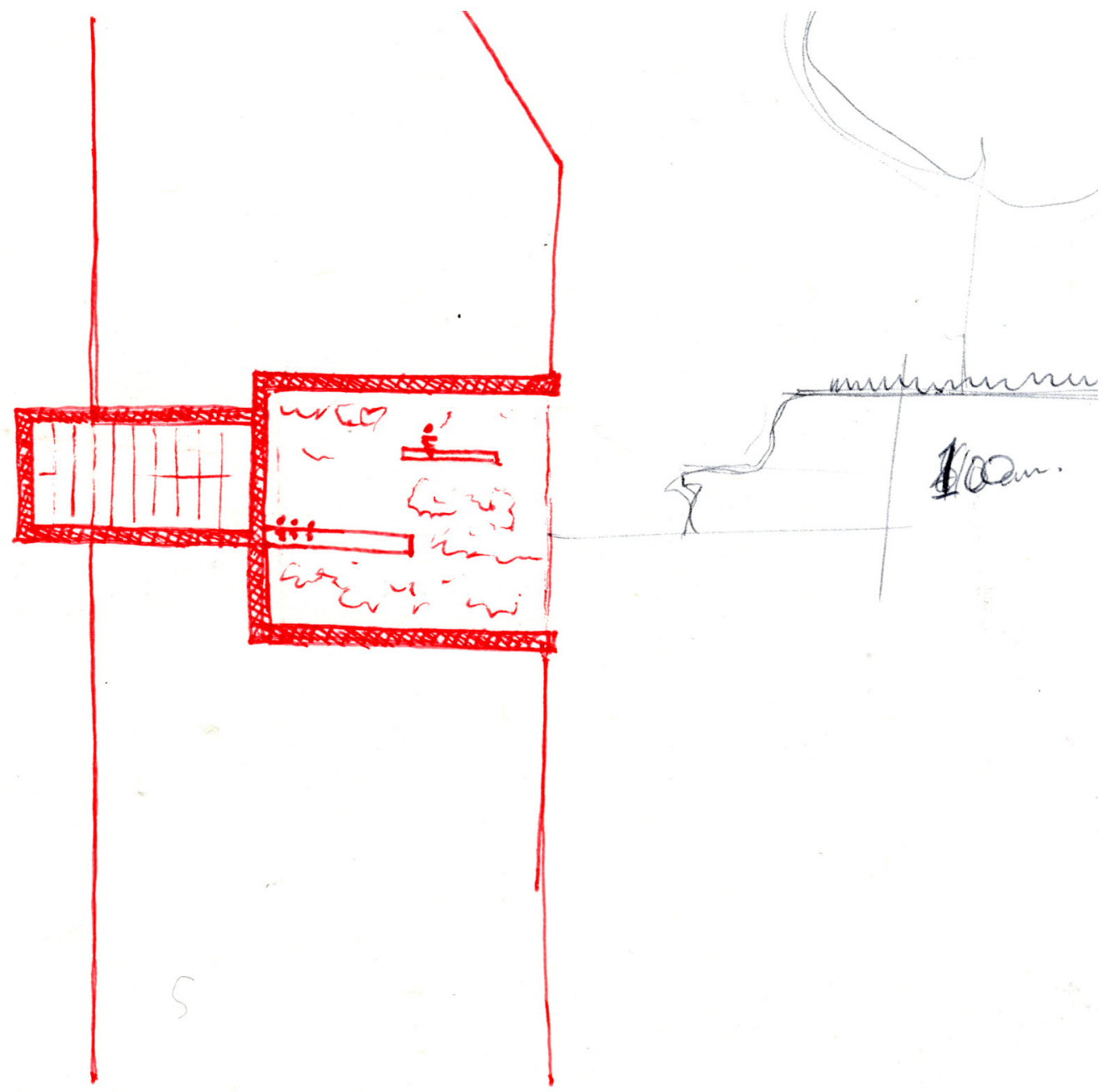

Programming Sketch Restaurant Elevation 
Section 6 :

Design

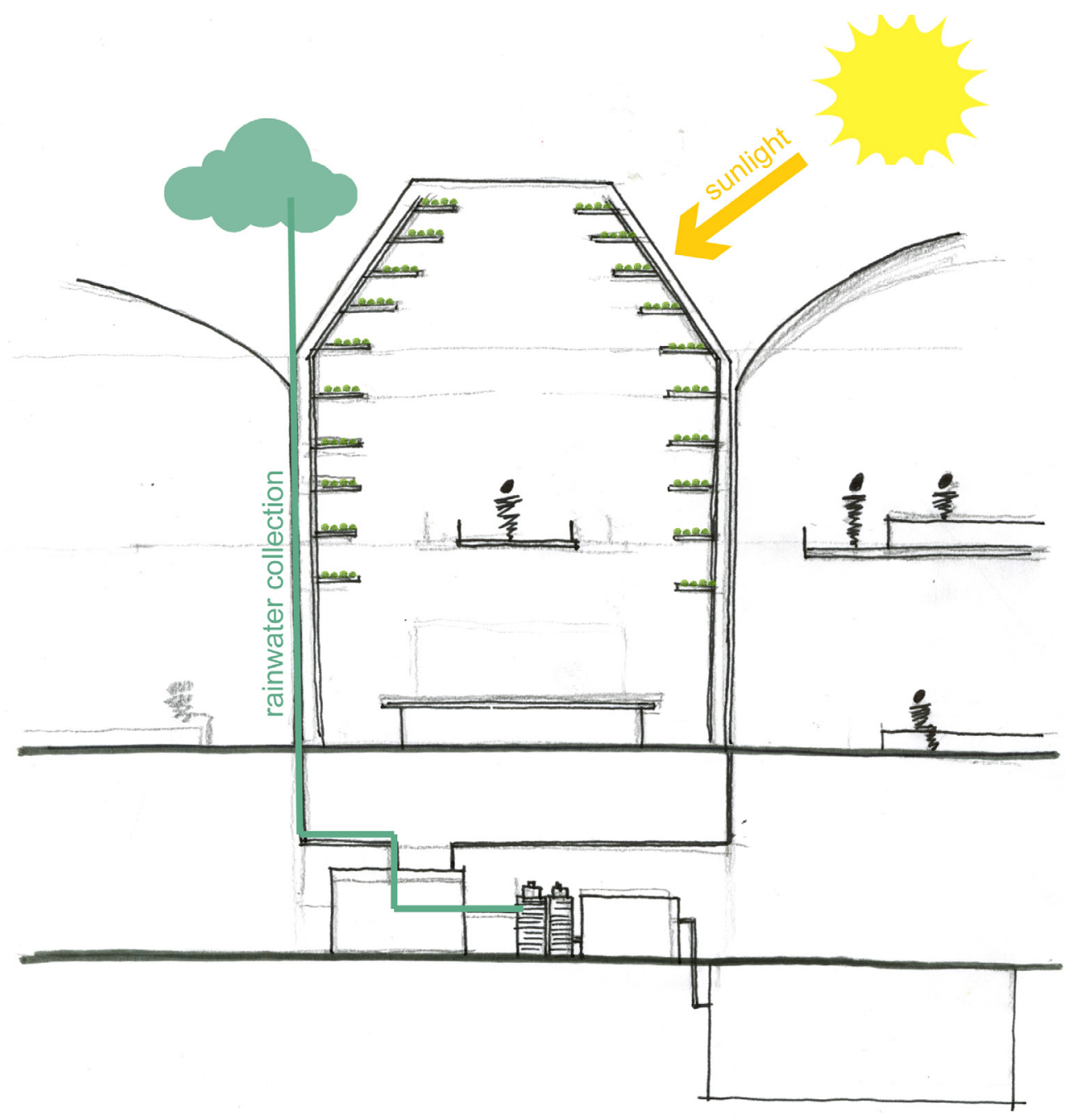

Programming Sketch Market Hydroponics 


\subsection{The Market}

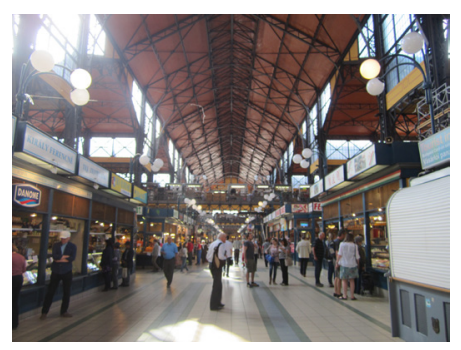

Image 23. Central Market Hall Budapest, Hungary

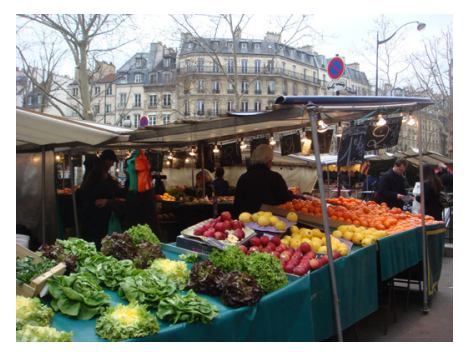

Image 24. Street Market Paris, France
The curtain walls of the market hall and the skylights on the roof above maximize the amount of natural light that comes through the space. This is further intensified with the exaggerated heights of the floor plates. An example of this lighting strategy can be experienced at the Central Market Hall in Budapest, Hungary, where glass panels above market stalls allow direct lighting from the sun. The structure of the Central Market Hall is also similar to that of the design project where the truss system supporting the roof is exposed.

The role of the market hall is to connect the source of food to the consumers who buy the produce, creating an intimate connection within a public realm. This is much like the street markets that can be found in cities such as Paris, France. Farmers set up make-shift tents and tables to sell their fresh produce to customers along the street. These streets will be created in the market hall of the thesis project. 


\subsection{The Crops}

The crops selected to be grown within the tower were chosen based on the most commonly consumed fruits and vegetables nationwide, based on of information provided Statistics Canada. Crops such as wheat, potatoes, and grains were not selected because of the structure and area required supporting the cultivation of the crop. Four vegetables and four fruits were chosen for the project, totaling $42 \%$ of the vegetables and $37 \%$ of the fruits consumed by the Distillery District in a year. The chosen vegetables and fruits were: lettuce, tomatoes, citrus fruits, cucumbers, bananas, carrots, onions, and melons. The population of 2500 people within the Distillery District was applied in the calculations concerning the amount of crops which would be grown within the structure, as well as information based on consumption per capita ${ }^{9}$. The positioning of the crops within the building was determined based on research of growing conditions needed by each individual crop. 
Section 6 :

Design

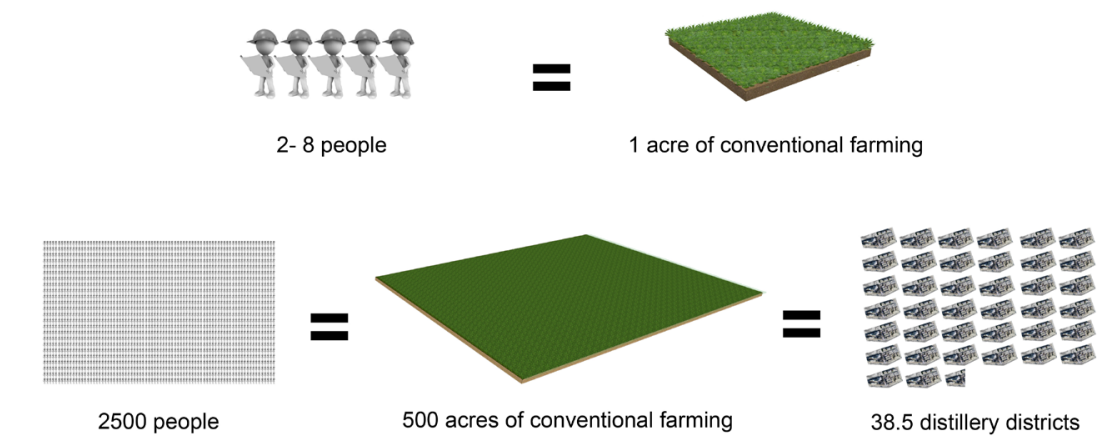
(population of distillery district)
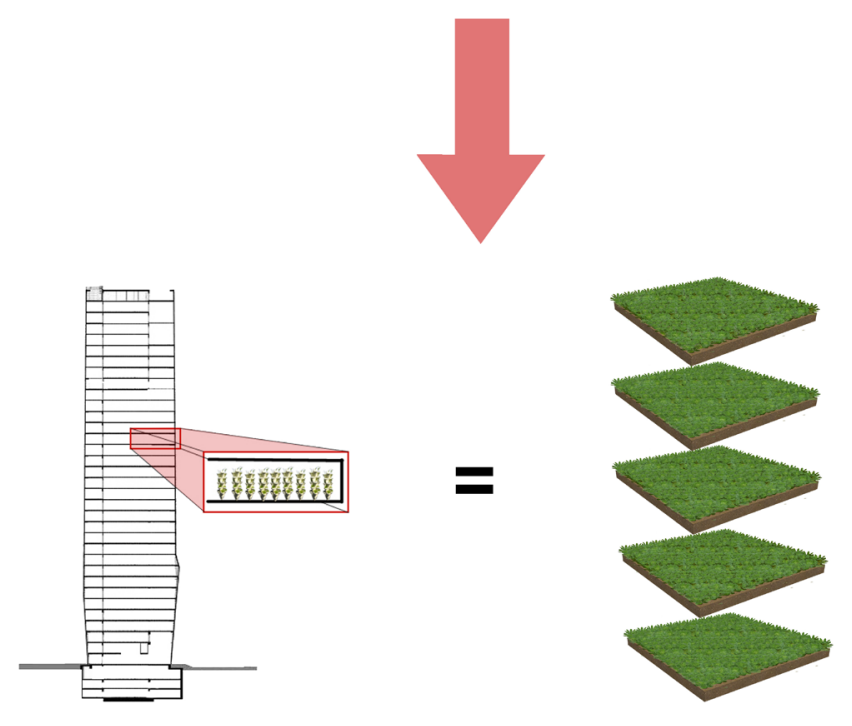

1 vertical farm acre

5 acres of conventional farming

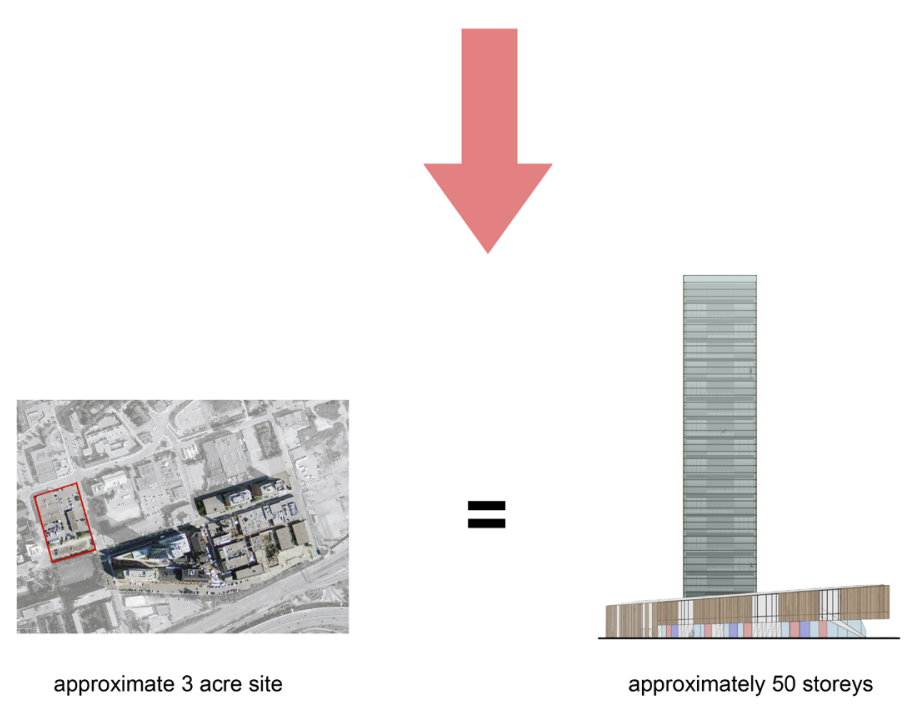

Diagram Feeding the Neighbourhood 
The following is a chart illustrating the information acquired about the crops and the calculations made in order to determine the number of plants needed in the tower.

\begin{tabular}{|c|c|c|}
\hline Crop & Research & Calculations \\
\hline Lettuce & $\begin{array}{l}10 \text { crops/year } \\
\text { Northeast Facade preferred } \\
\text { NFT system } \\
\text { - Low light } \\
-12 \text { hours of light } \\
\end{array}$ & $\begin{array}{l}\text { - Average Consumption: } 5.65 \mathrm{~kg} / \mathrm{person} \\
\text { - Distillery District (2500 people): } 14,125 \mathrm{~kg} \\
\text { - Average Head of Lettuce (Cos): } 0.75 \mathrm{~kg} / \mathrm{head} \\
\text { - } 1 \text { Hydroponic Crop Yield:10 crops/year } \\
\text { - Total Plants }=1884 \text { plants }\end{array}$ \\
\hline Tomatoes & $\begin{array}{l}\text { Short day plant } \\
-9 \text { hours of light } \\
\text { East-West Facade during winter, North- } \\
\text { South faced in summer }\end{array}$ & $\begin{array}{l}\text { - Average Consumption: } 4.31 \mathrm{~kg} / \mathrm{person} \\
\text { - Distillery District (2500 people): 10,775 kg } \\
\text { - Average Plant Yield: } 7-10 \mathrm{~kg} / \mathrm{plant} \\
\text { - } 1 \text { Hydroponic Crop Yield: } 2 \text { crops/year } \\
\text { - Total Plants = } 770 \text { plants }\end{array}$ \\
\hline Citrus & \begin{tabular}{|l||} 
Good Light \\
-8 hours of light \\
- South Facing Preferred \\
- Light and Heat \\
- Good Indoor Growing Varieties (Dwarf): \\
o Washington Navel Orange: 8'-12' \\
o Meyer Lemon: 6'-10' \\
o Mexican Key Lime: 6'-10' \\
o Oroblanco Grapefruit: 8'-12' \\
\end{tabular} & $\begin{array}{l}\text { - Average Consumption (Dwarf Washington Navel } \\
\text { Oranges): } 4.74 \mathrm{~kg} / \text { person } \\
\text { - Distillery District (2500 people): } 11,850 \mathrm{~kg} \\
\text { - Average Plant Yield: } 200 \text { pounds over } 5 \text { year } \\
\text { period }=18.143694 \mathrm{~kg} / \mathrm{year} \\
\text { - Total Plants }=654 \text { plants } \\
\end{array}$ \\
\hline Cucumber & $\begin{array}{l}\text { 44-55 day harvest } \\
-25,000 \text { plants per hectare } \\
\text { NFT system } \\
\text { - Trained up strings up to } 2 \mathrm{~m} \text { high } \\
\text { - Must be pruned every } 7-10 \text { days } \\
-16-18 \text { inches apart } \\
\text {-6-7 fruits at any point in time } \\
\text { 400-550 grams/plant }\end{array}$ & $\begin{array}{l}\text { - Average Consumption (Dwarf Washington Navel } \\
\text { Oranges): } 2.29 \mathrm{~kg} / \text { person } \\
\text { - Distillery District (2500 people): } 5,725 \mathrm{~kg} \\
\text { - } 1 \text { Hydroponic Crop Yield: } 40 \text { day plant cycle } \\
\text { - Average Plant Yield: } 0.4 \mathrm{~kg} / \mathrm{cucumber} \\
6 \text { cucumbers at a time: } 2.4 \mathrm{~kg} \\
\text { - Total Plants = } 266 \text { plants }\end{array}$ \\
\hline Banana & $\begin{array}{l}\text { Super Dwart Cavendish } \\
\text { - Drip hydroponic systems: } 20 \text { gallon } \\
\text { eservoirs } \\
\text { Full or partial sun } \\
\text { - Maximum sunlight } \\
12 \text { hours of bright light } \\
\text { - The average bunch weight with } 6-7 \\
\text { hands and with about } 13 \text { fruits per hand } \\
\text { is about } 15-25 \mathrm{~kg} \\
1.2 \mathrm{~m}\end{array}$ & $\begin{array}{l}\text { - Average Consumption (Dwart Washington Nave } \\
\text { Oranges): } 6.65 \mathrm{~kg} / \text { person } \\
\text { - Distillery District (2500 people): } 16,625 \mathrm{~kg} \\
\text { - } 1 \text { Hydroponic Crop Yield: } 78 \text { bananas/year per } \\
\text { plant } \\
\text { - Average Plant Yield: } 15 \mathrm{~kg} \\
\text { - Total Plants = } 1109 \text { plants } \\
\end{array}$ \\
\hline Carrot & $\begin{array}{l}\text { - Perlite hydroponic system } \\
-16 \text { hours of sunlight } \\
-32 \text { quart bin } \\
-2.5-3 \text { months cycle }\end{array}$ & $\begin{array}{l}\text { - Average Consumption: } 5.46 \mathrm{~kg} / \mathrm{person} \\
\text { - Distillery District (2500 people): } 13,650 \mathrm{~kg} \\
\text { - } 1 \text { Hydroponic Crop Yield: } 4 \text { carrots a year } \\
\text { - Average Weight for } 1 \text { Carrot: } 0.061 \mathrm{~kg} \\
\text { - Total Plants }=55,943 \text { plants }\end{array}$ \\
\hline Onion & $\begin{array}{l}\text { Hydroponics } 6 \text { inches deep } \\
\text { Spring onions } 1 \text { inch apart, large } \\
\text { onions } 3 \text { inches apart } \\
-1 \text { square foot: } 60 \text { onions } \\
\text { Large onion: } 60 \text { day crop cycle } \\
\text { Short day onion: } 10-12 \text { hours } \\
\text { - Medium light }\end{array}$ & $\begin{array}{l}\text { - Average Consumption: } 4.12 \mathrm{~kg} / \text { person } \\
\text { - Distillery District (2500 people): } 10,300 \mathrm{~kg} \\
\text { - } 1 \text { Hydroponic Crop Yield: } 60 \text { day cycle }=6 \\
\text { onions a year } \\
\text { - Average Weight for } 1 \text { Onion: } 0.28 \mathrm{~kg} \\
\text { - Total Plants = } 6131 \text { plants }\end{array}$ \\
\hline Melon & $\begin{array}{l}-12 \text { inch hydroponic pots } \\
\text { Each pot has } 1 \text { melon plant } \\
\text { Crop cycle is } 65 \text { days } \\
-1.5 \text { kg melon each } \\
-8 \text { hours of sun }\end{array}$ & $\begin{array}{l}\text { Average Consumption: } 3.59 \mathrm{~kg} / \text { person } \\
\text { - Distillery District }(2500 \text { people): } 8,975 \mathrm{~kg} \\
-1 \text { Hydroponic Crop Yield: } 60 \text { day cycle }=5 \\
\text { melons a year } \\
\text { - Average Weight for } 1 \text { Melon: } 1.5 \mathrm{~kg} \\
\text { - Total Plants }=1197 \text { plants }\end{array}$ \\
\hline
\end{tabular}


Section 6 :
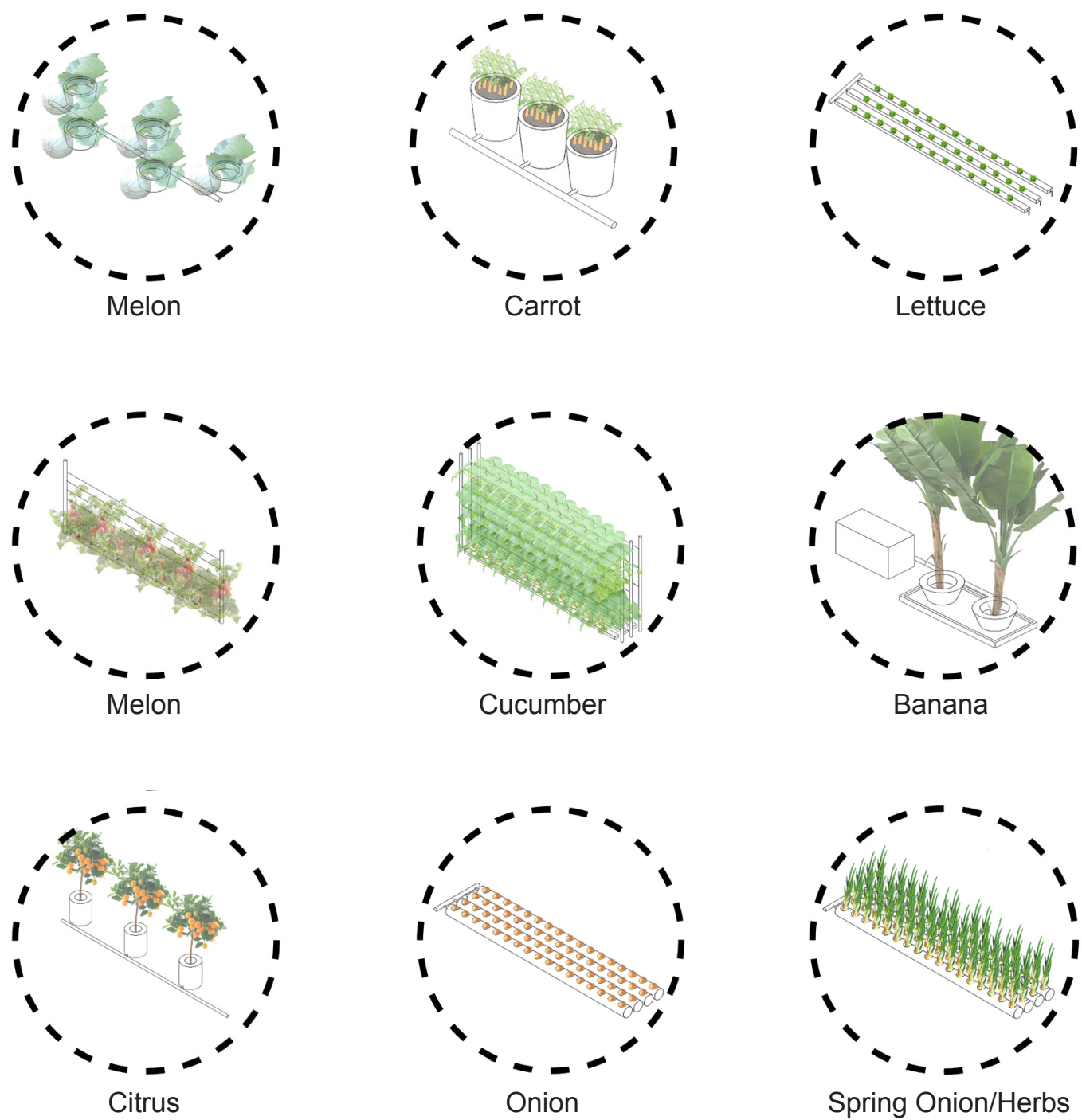

Diagram Hydroponic Design 
Section 6 :

Design

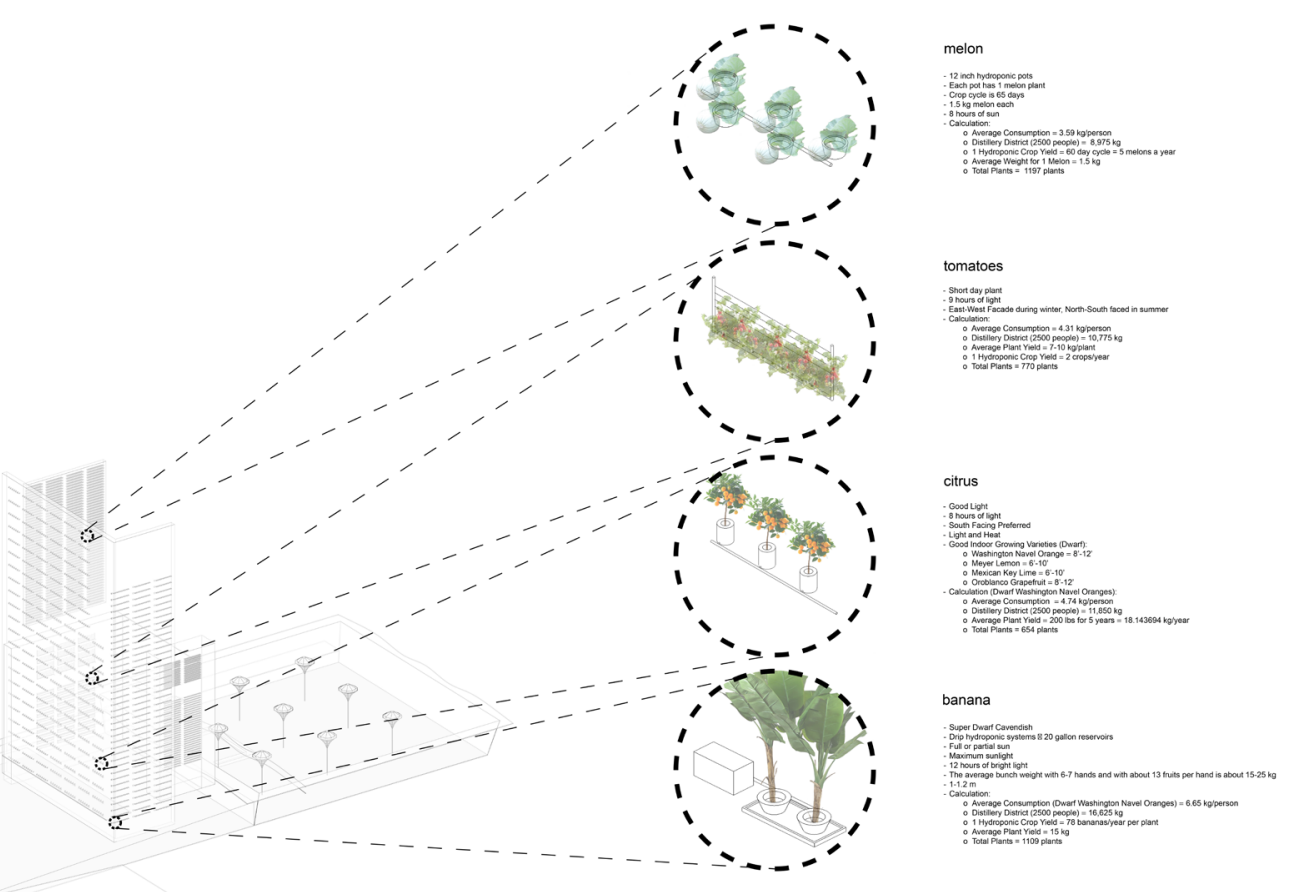

Diagram Hydroponic Fruits Locations 
Section 6 :

Design

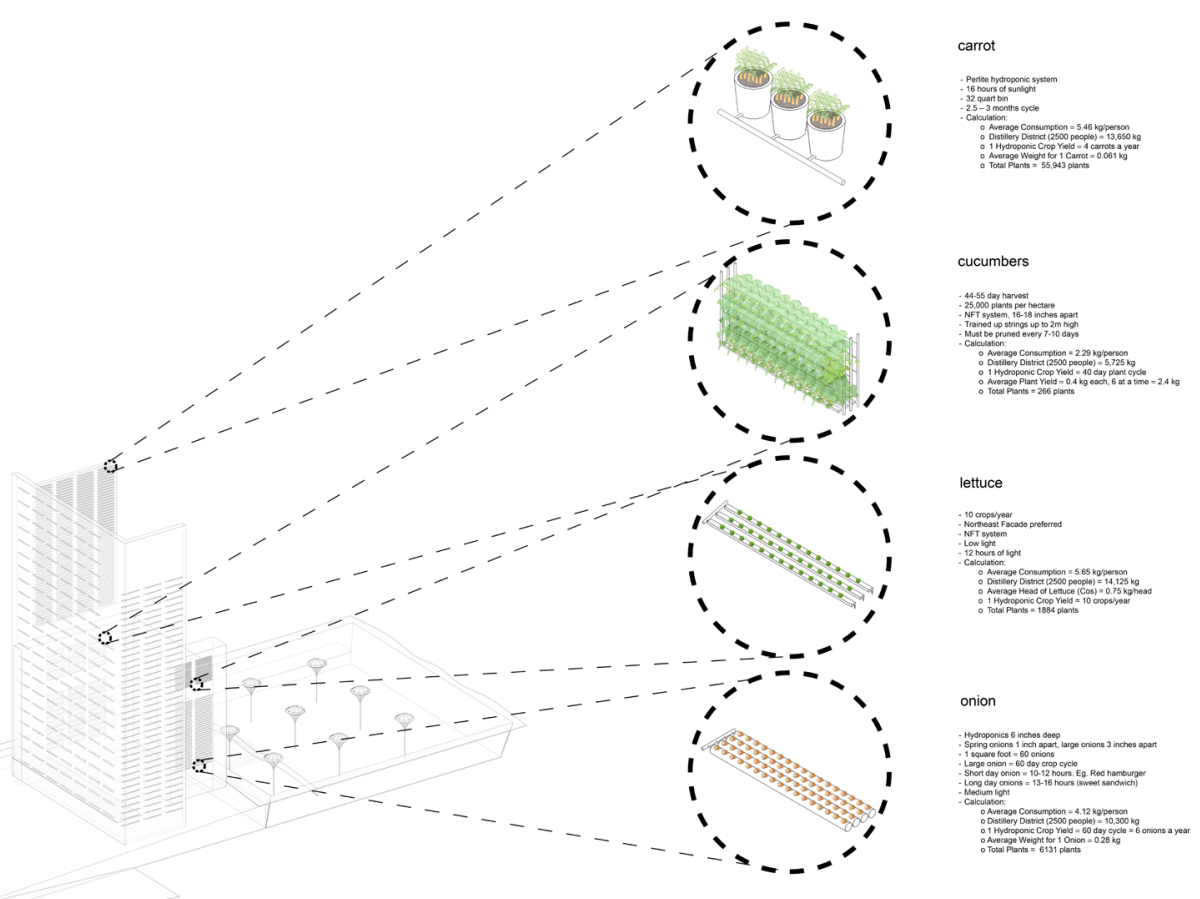

Diagram Hydroponic Vegetables Locations 
Section 6 :

Design

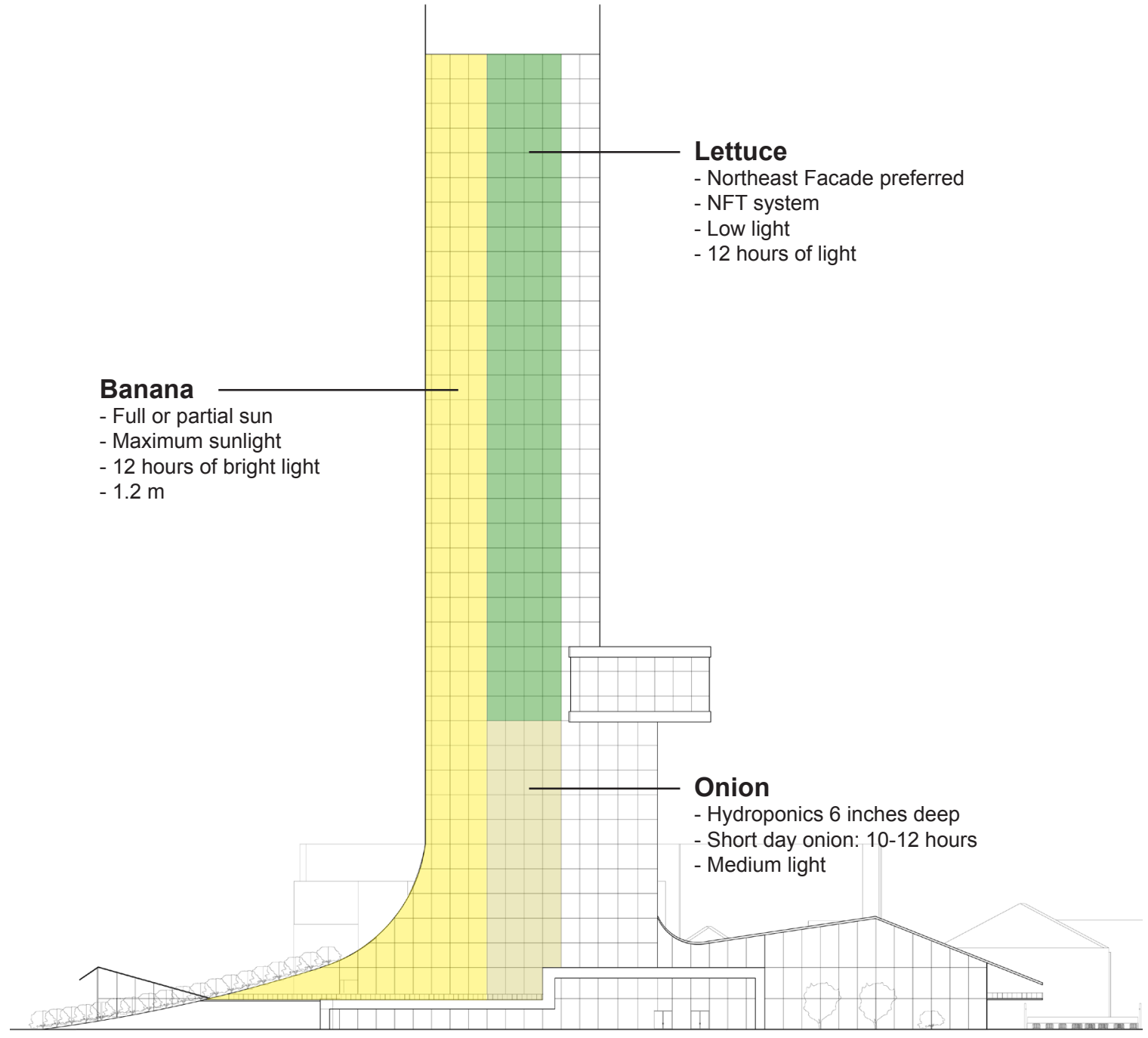

Diagram Hydroponic Locations East Facade 
Design

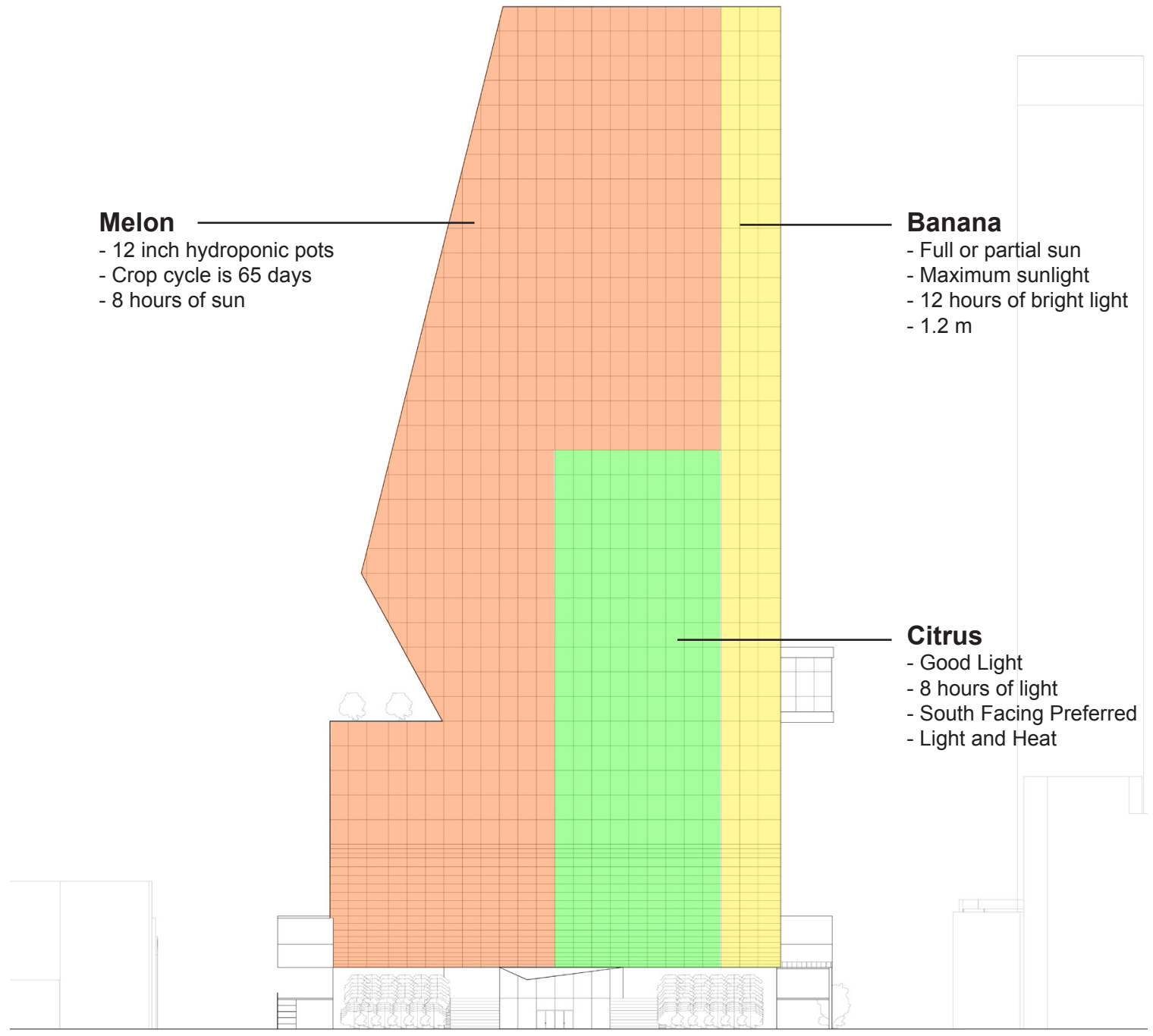

Diagram Hydroponic Locations South Facade 
Section 6 :

Design

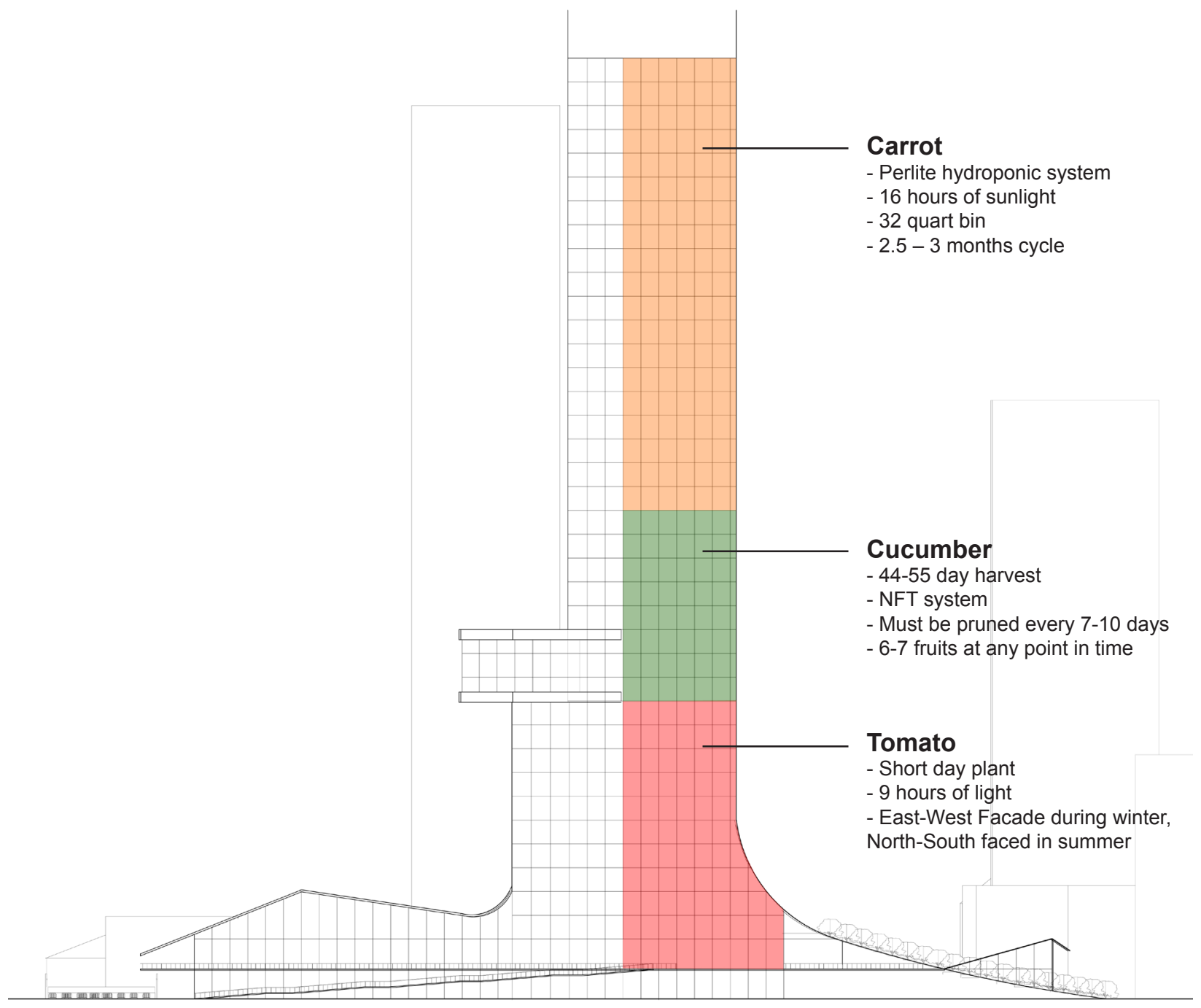

Diagram Hydroponic Locations West Facade 
Section 6 :

Design

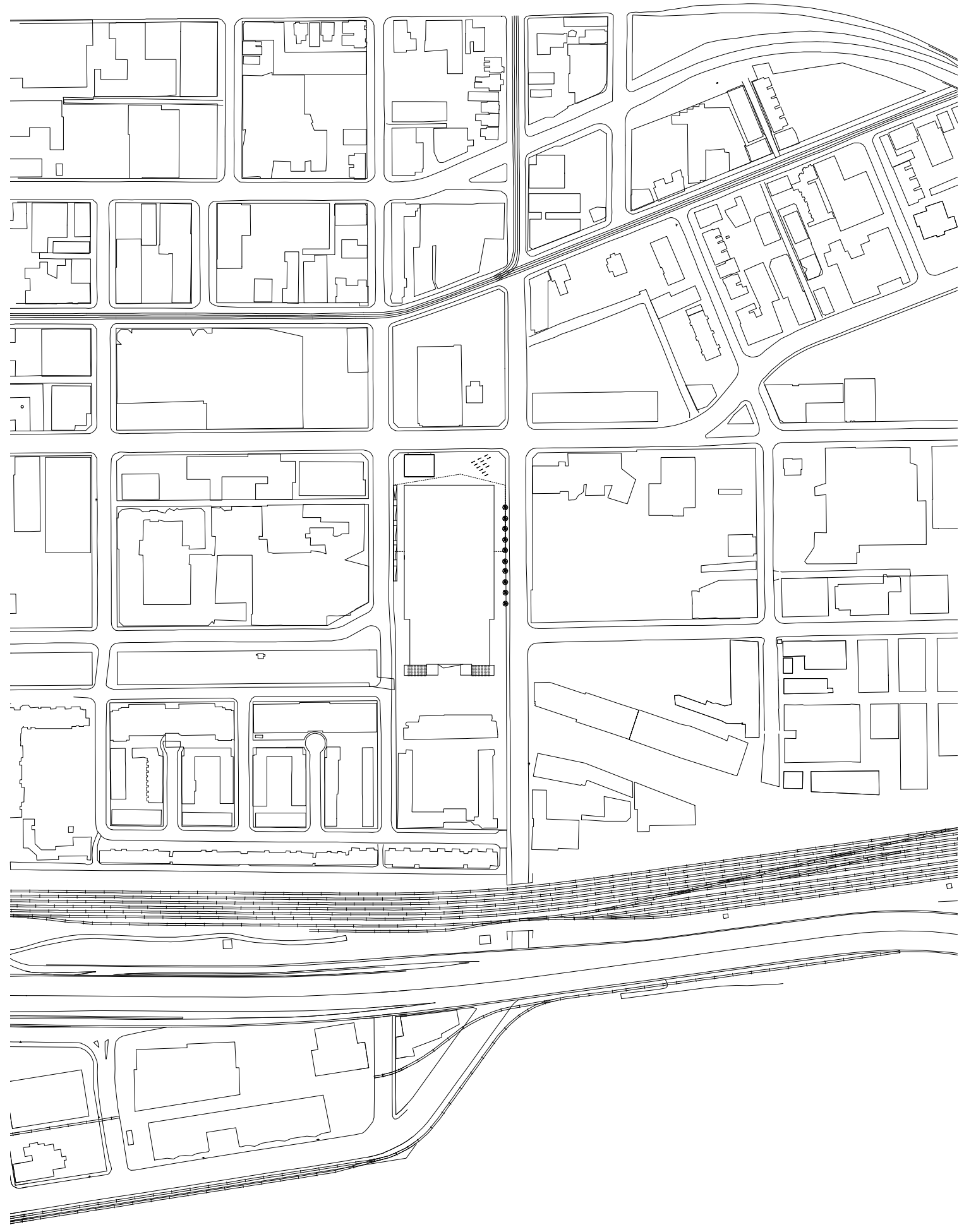


Section 6 :

Design

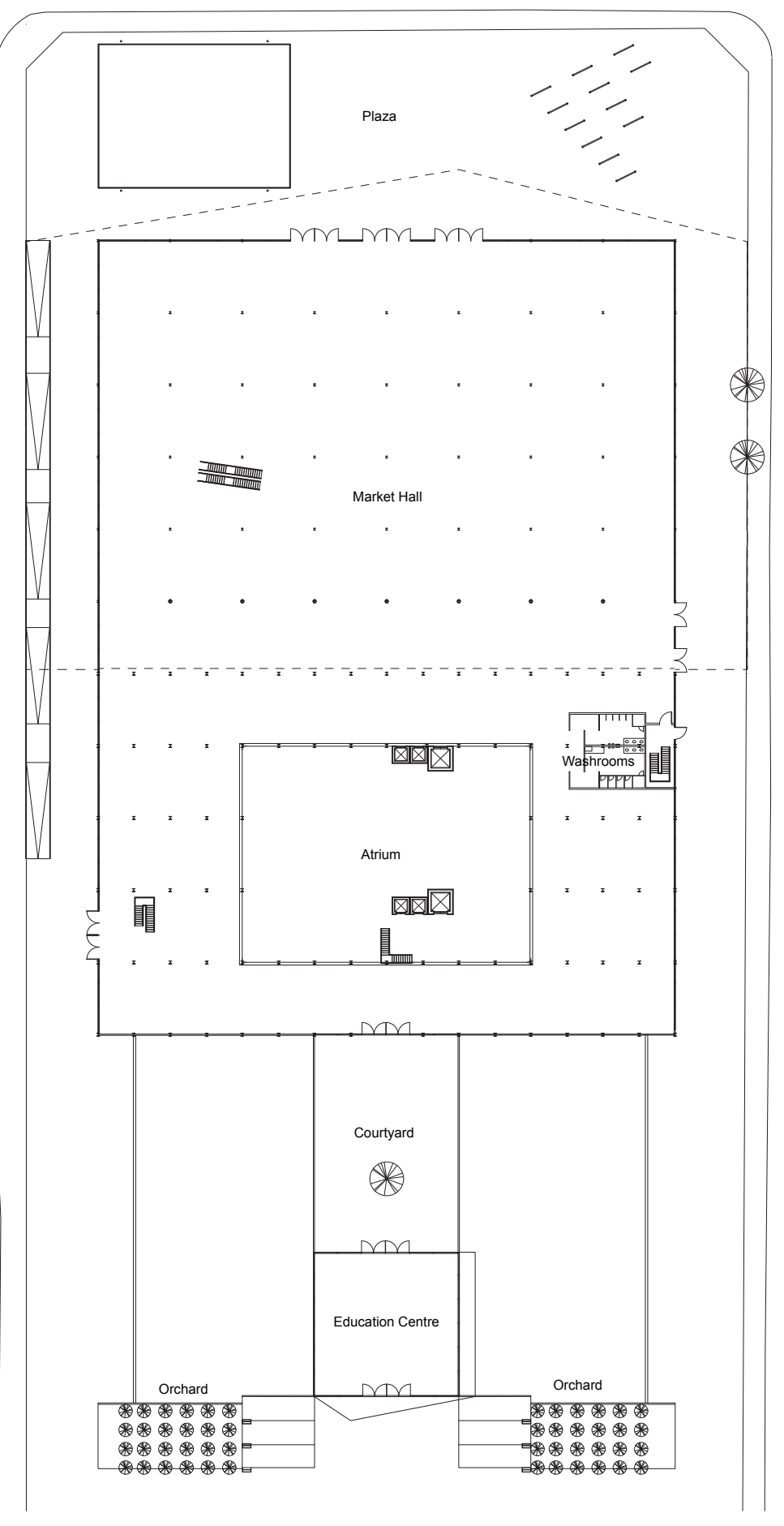

Level 1 Plan 1:1000 
Section 6 :

Design

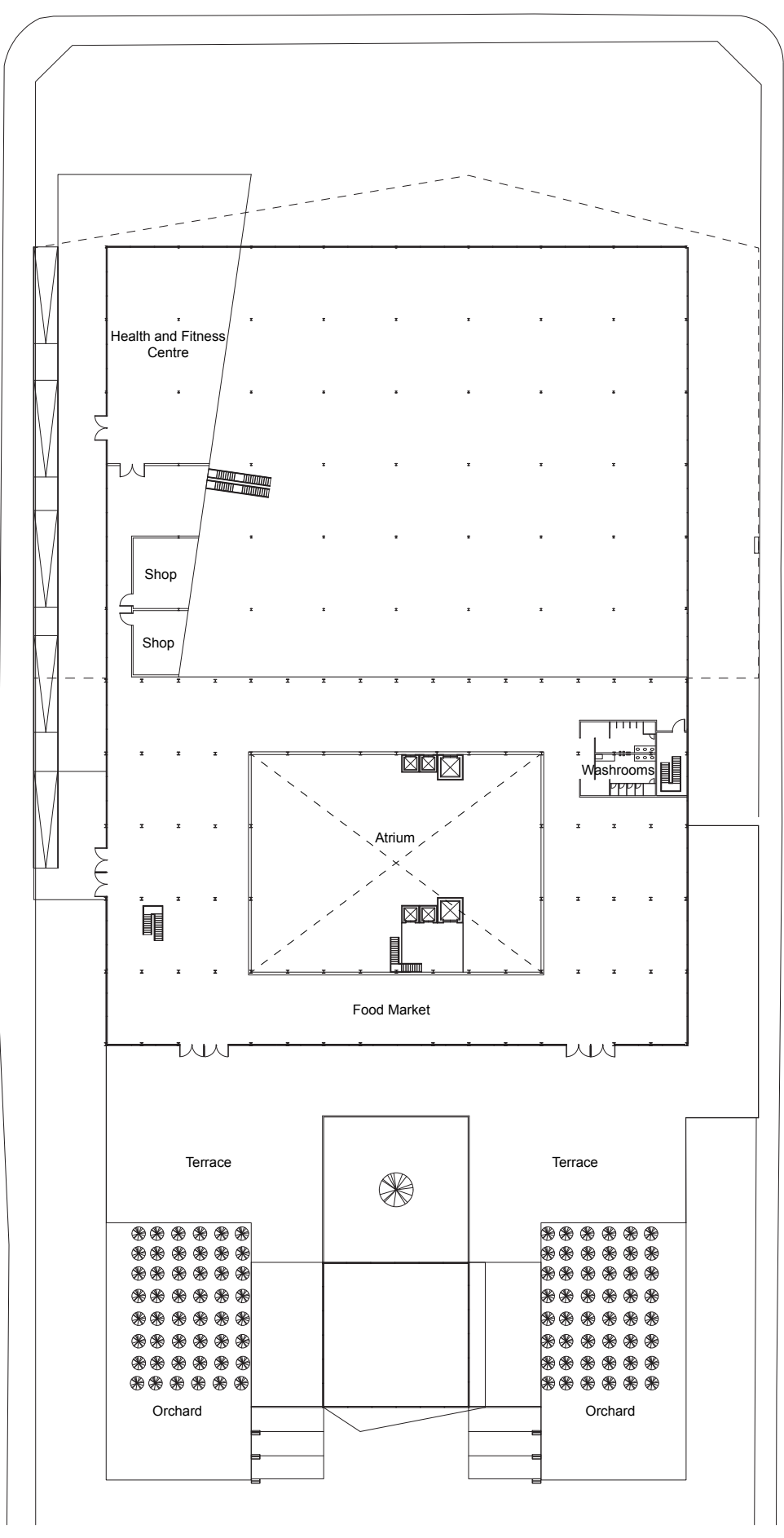

Level 2 Plan 1:1000 
Section 6 :

Design

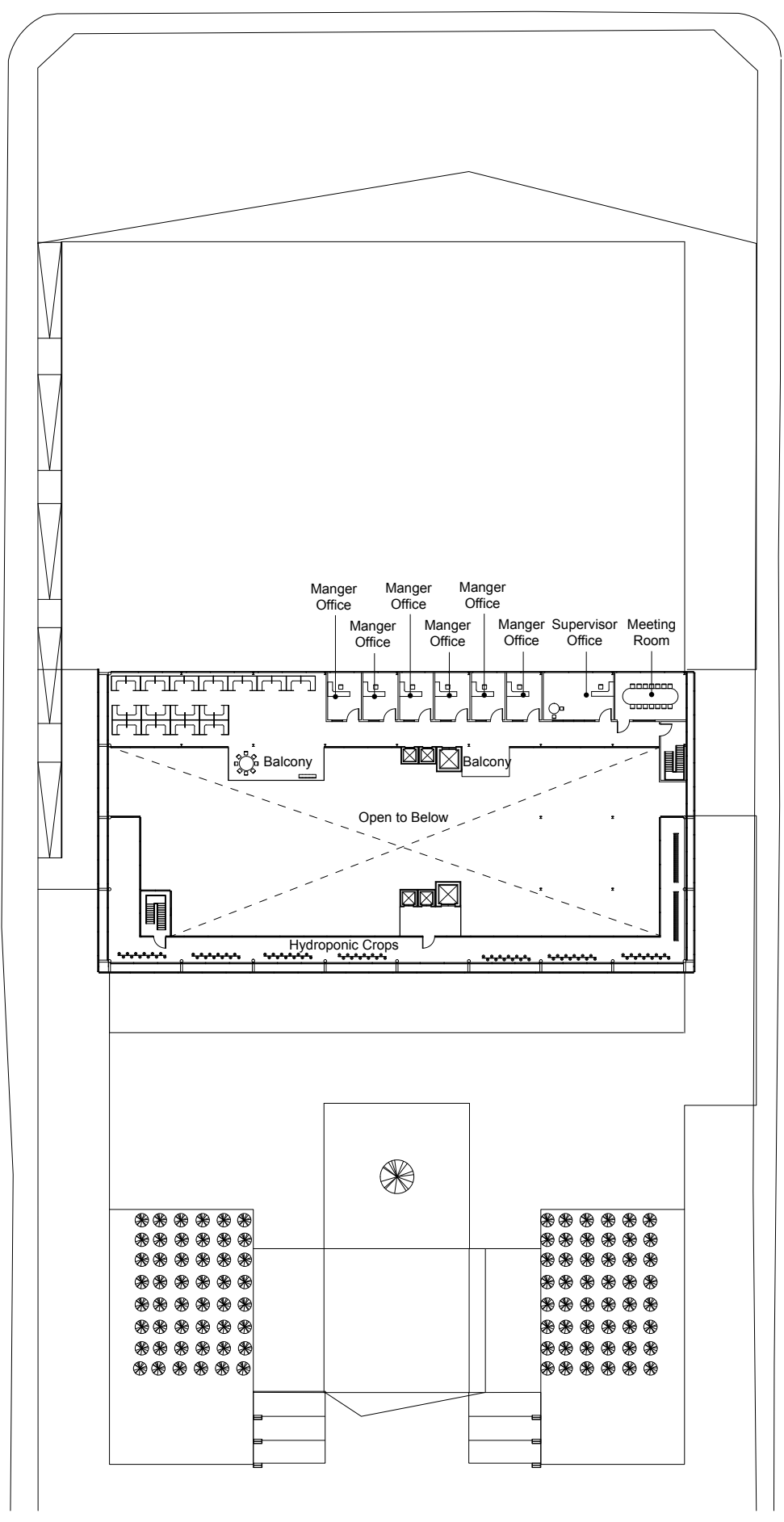

Level 6 Plan 1:1000 
Section 6 :

Design

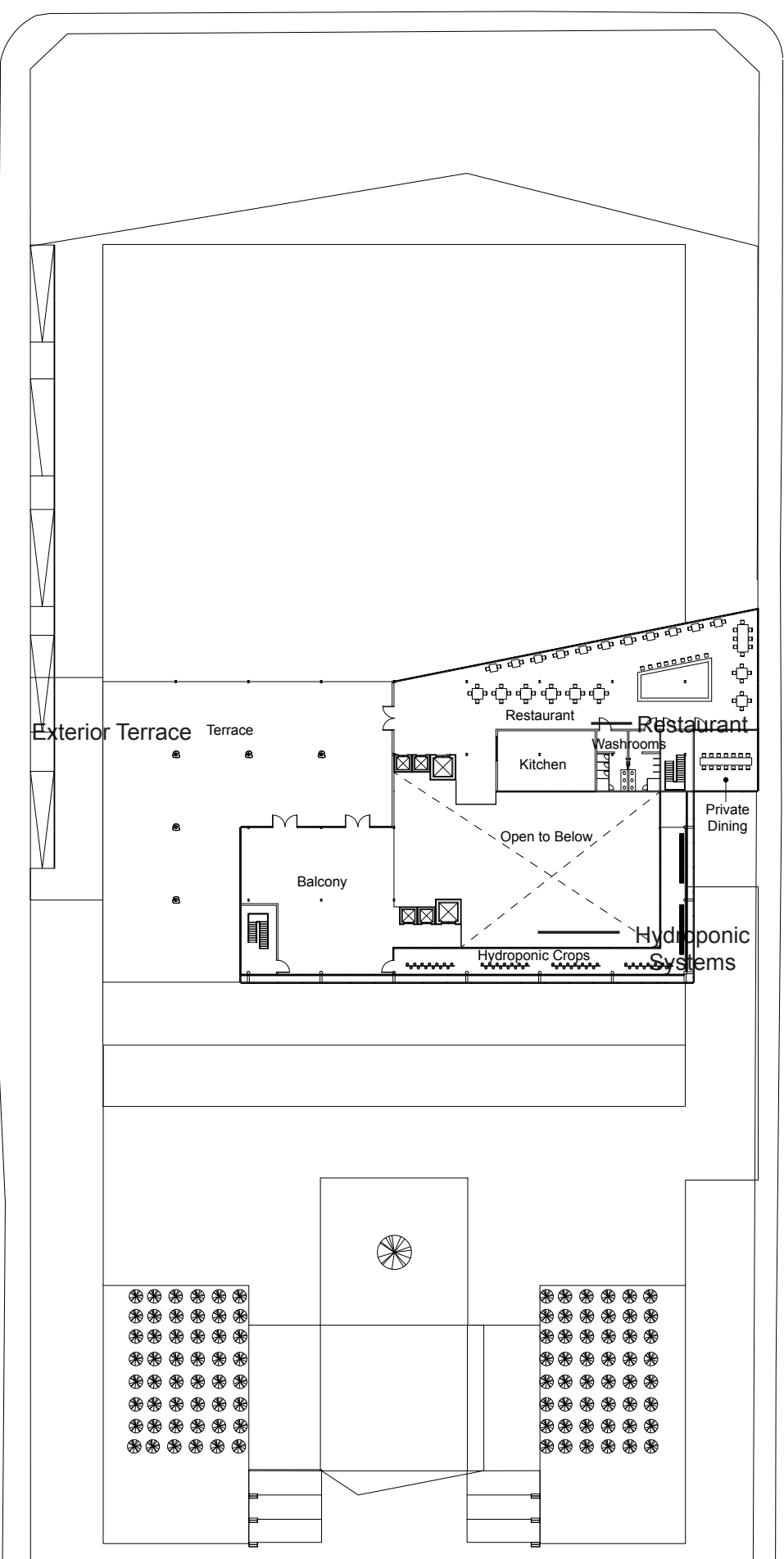

Level 13 Plan 1:1000 
Section 6 :

Design
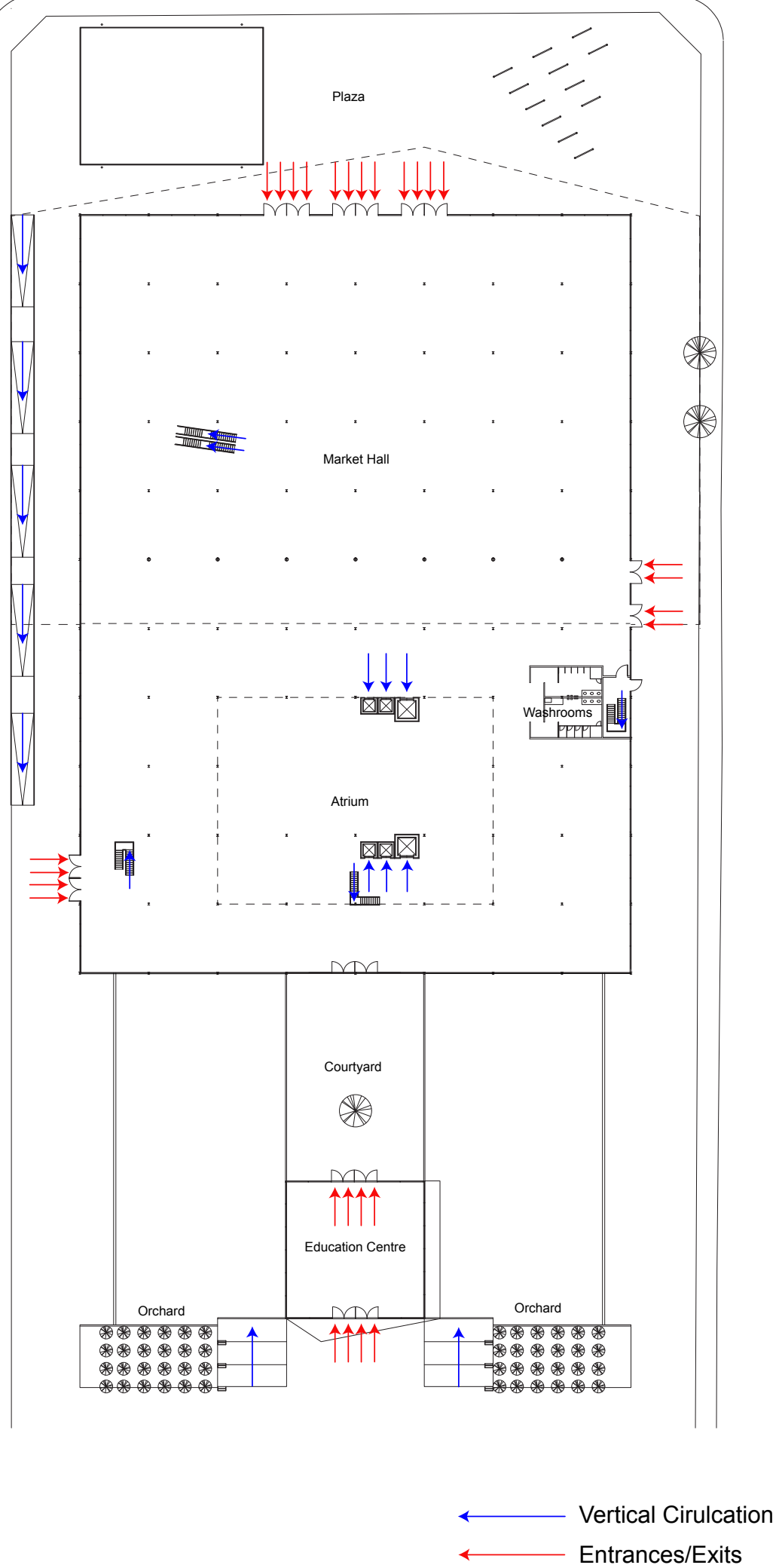

Circulation Diagram Level 1 
Section 6 :

Design
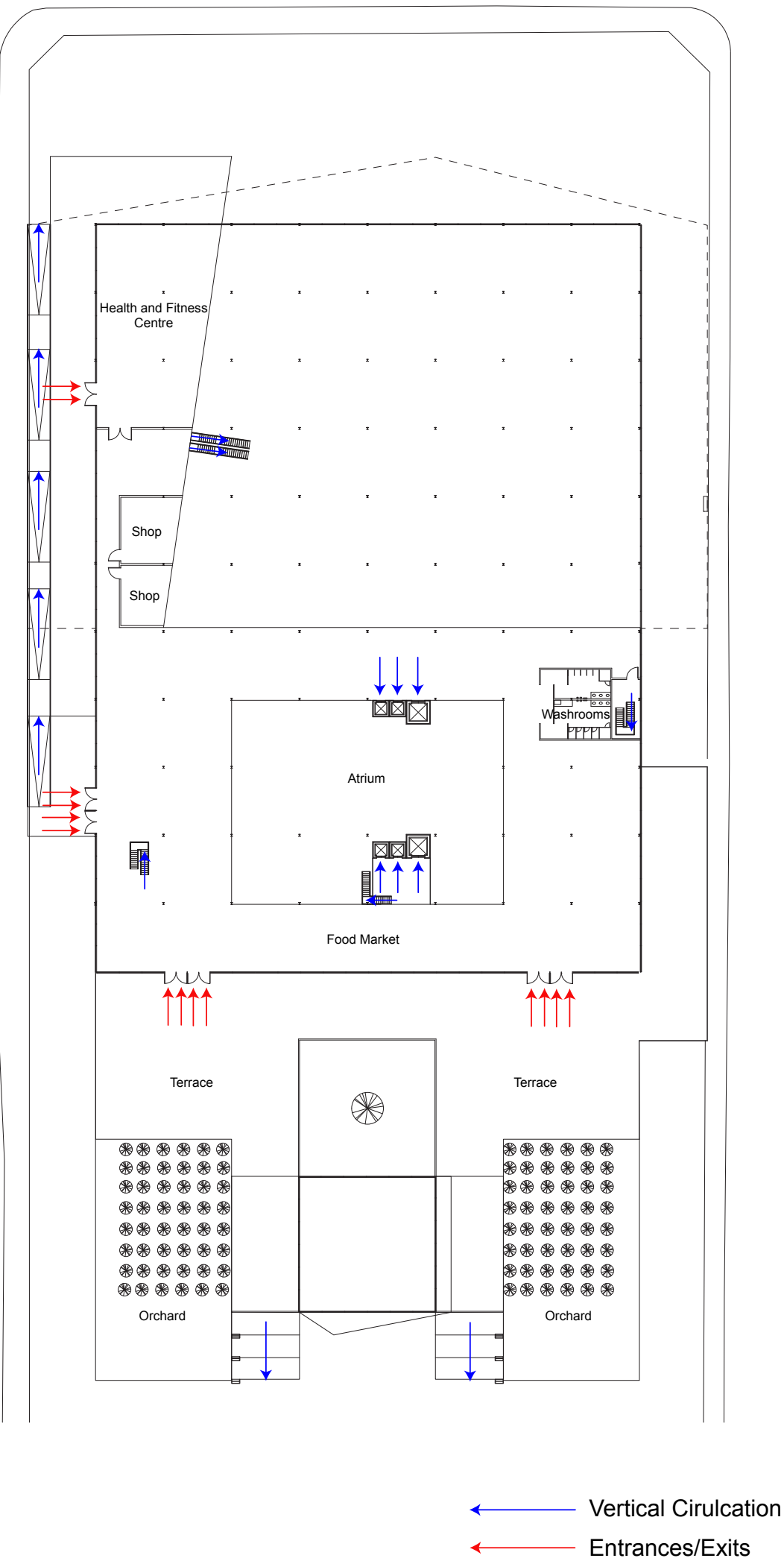

Circulation Diagram Level 2 
Section 6 :

Design
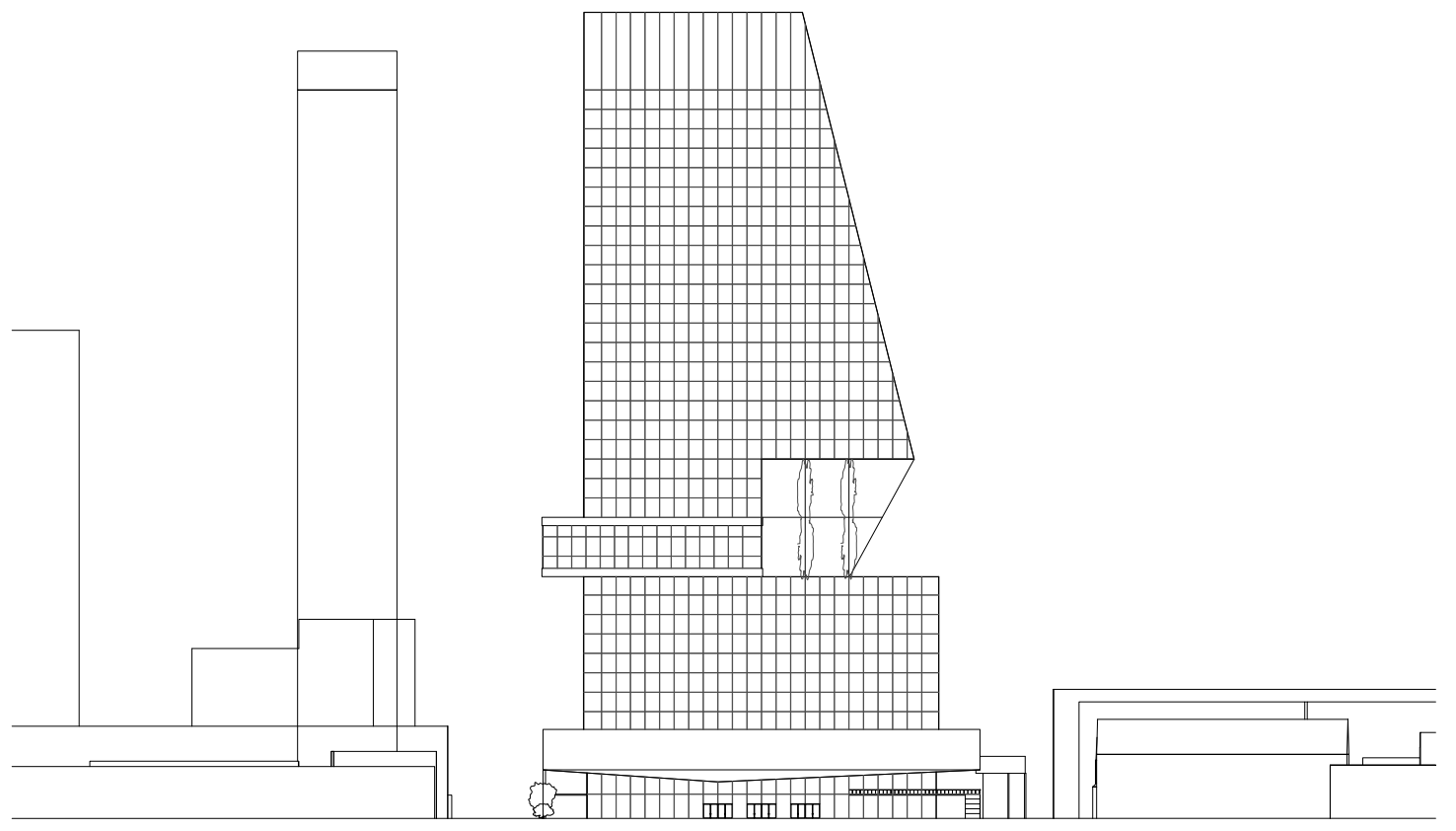

North Elevation 1:2000

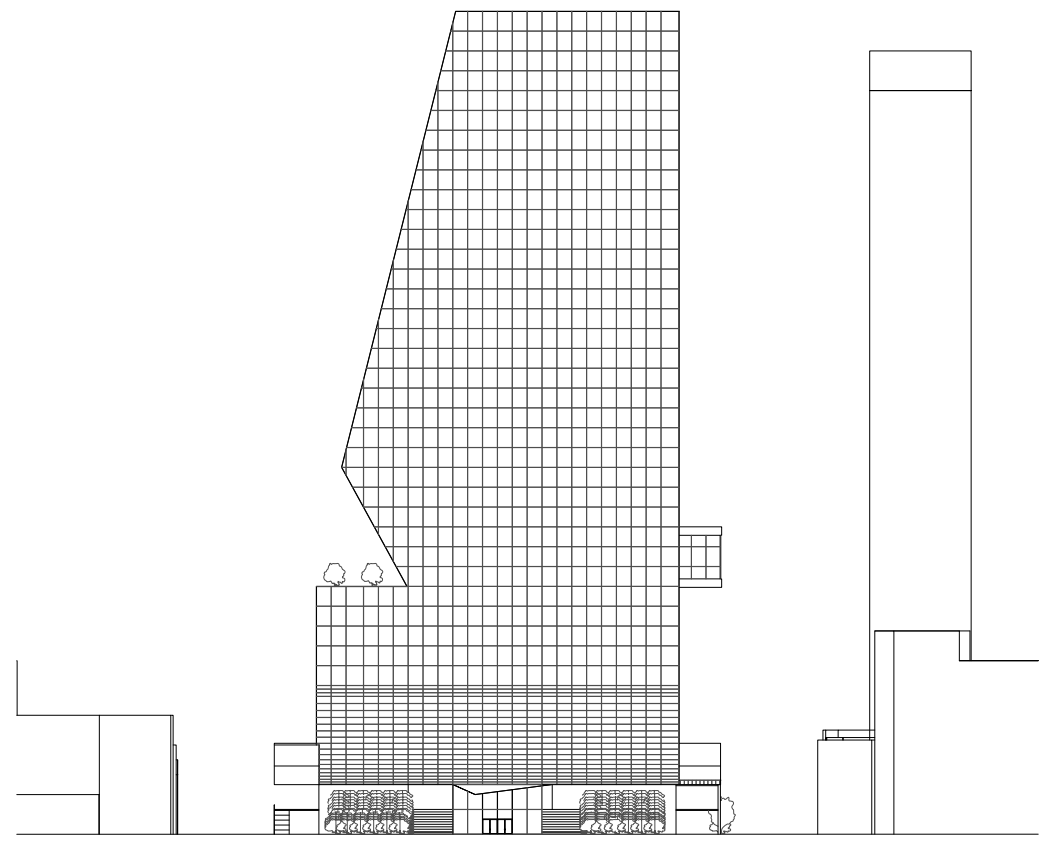

South Elevation 1:2000 
Section 6 :

Design

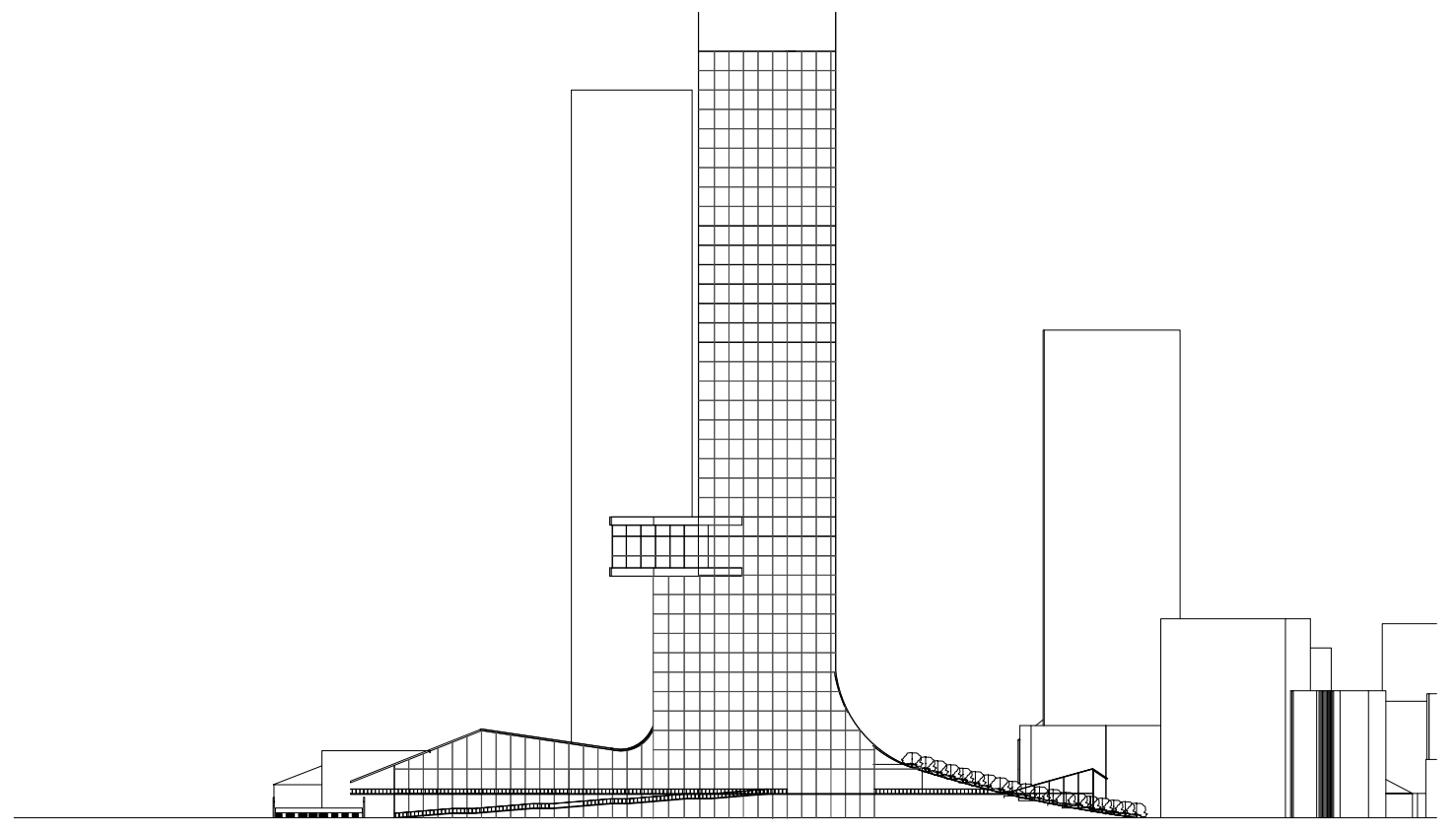

East Elevation 1:2000

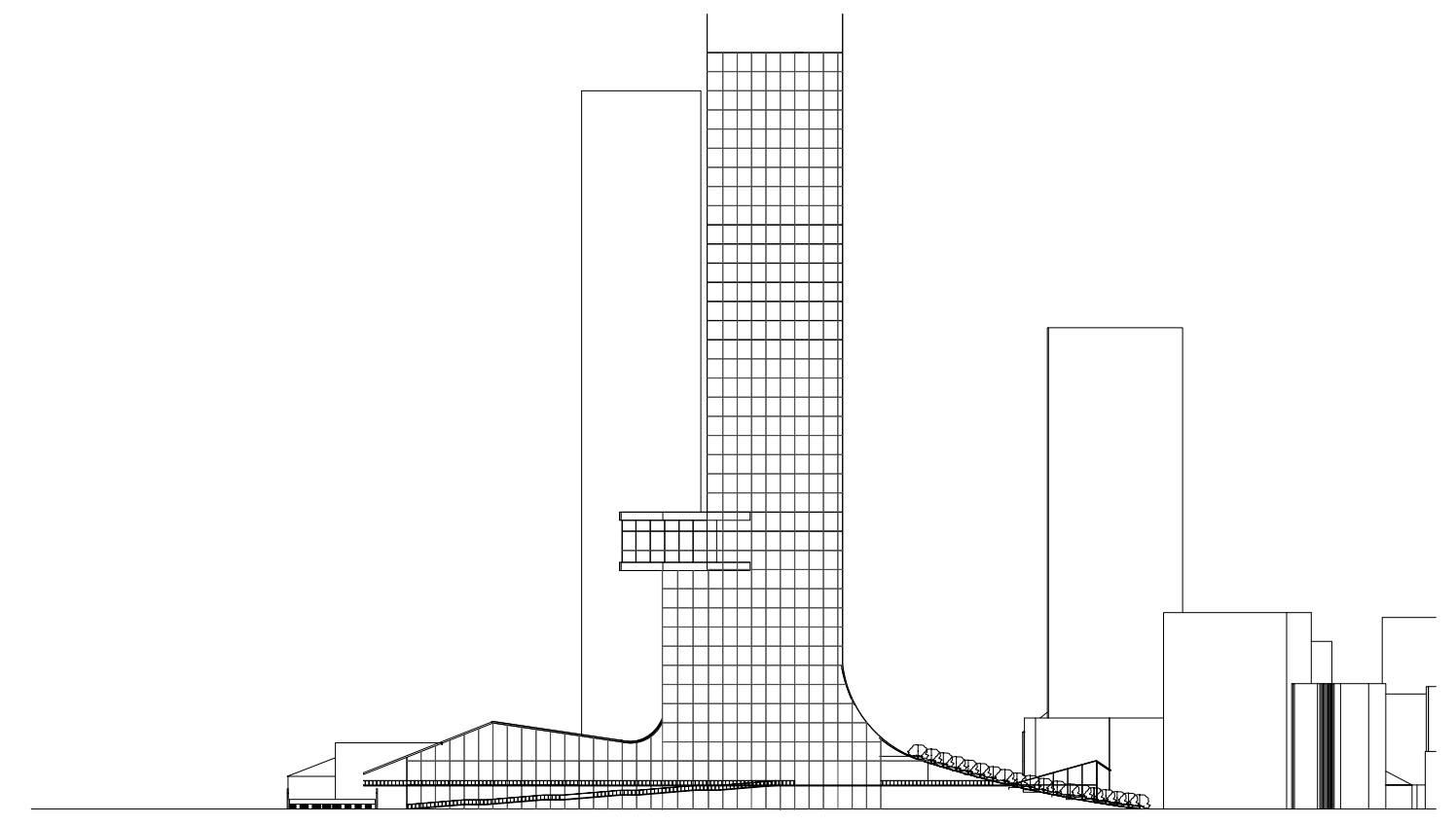

West Elevation 1:2000 
Section 6 :

Design

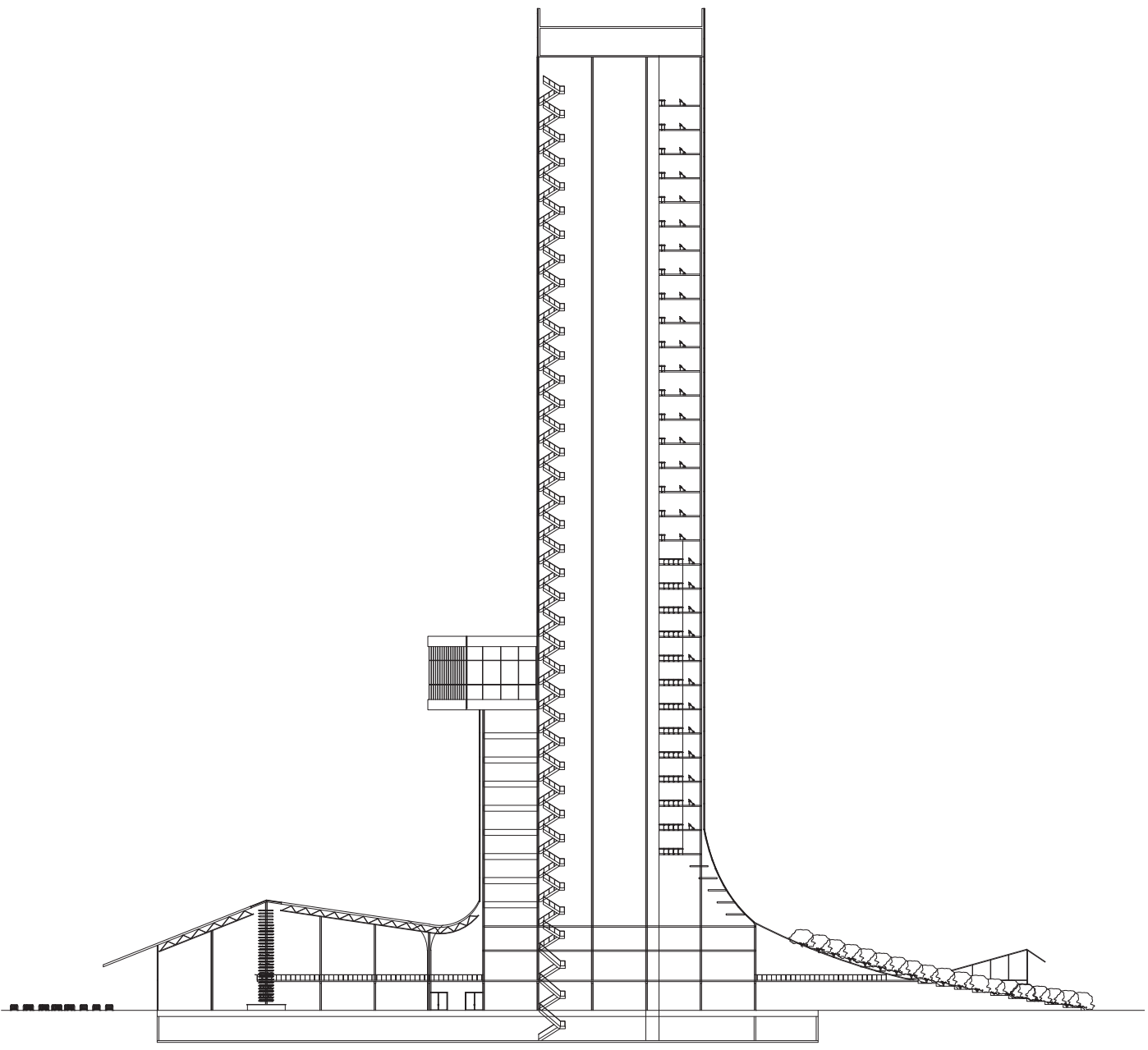

Section 1:1250 
Section 6 :

Design

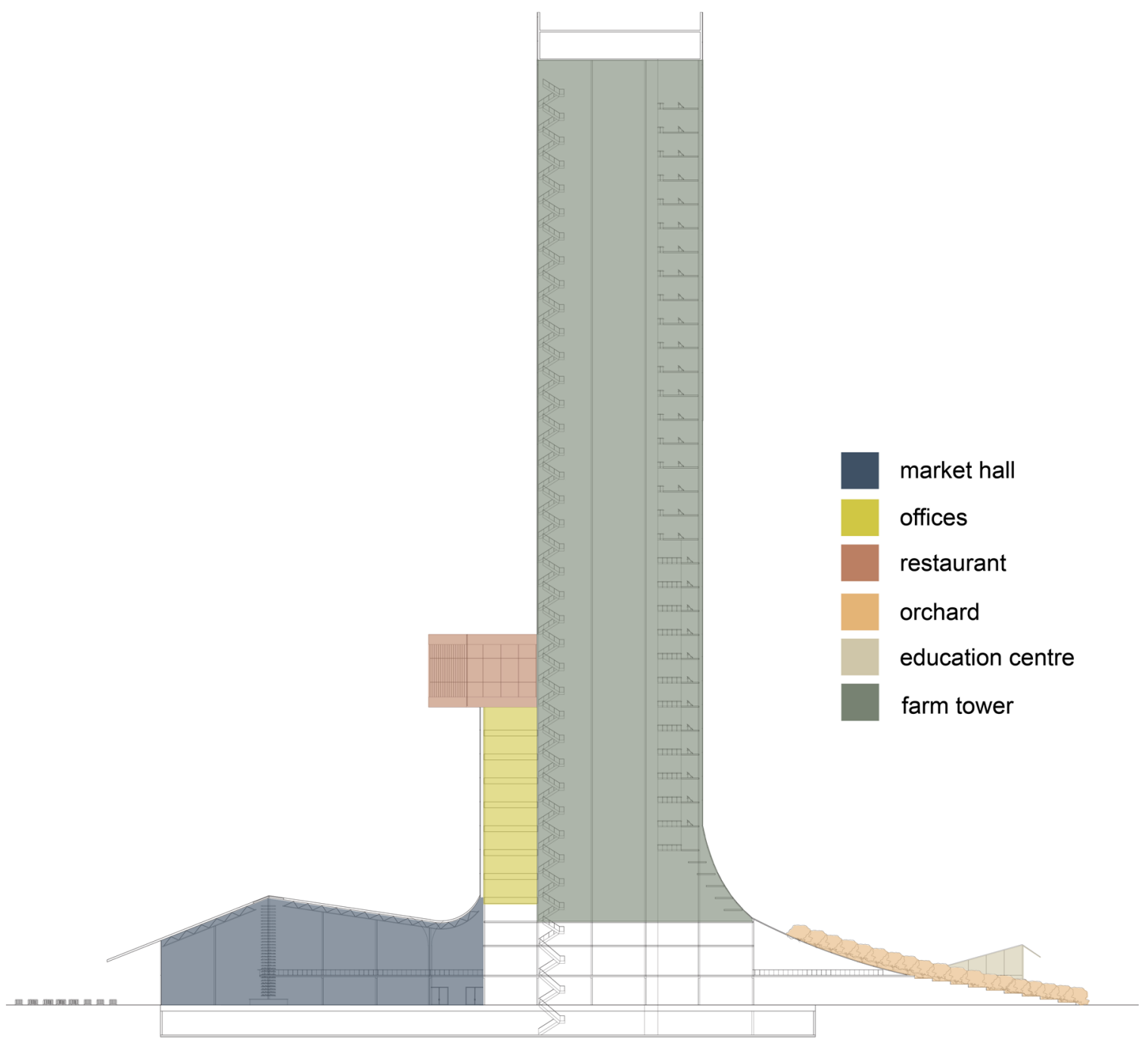

Programming Diagram Section 
Section 6 :

Design

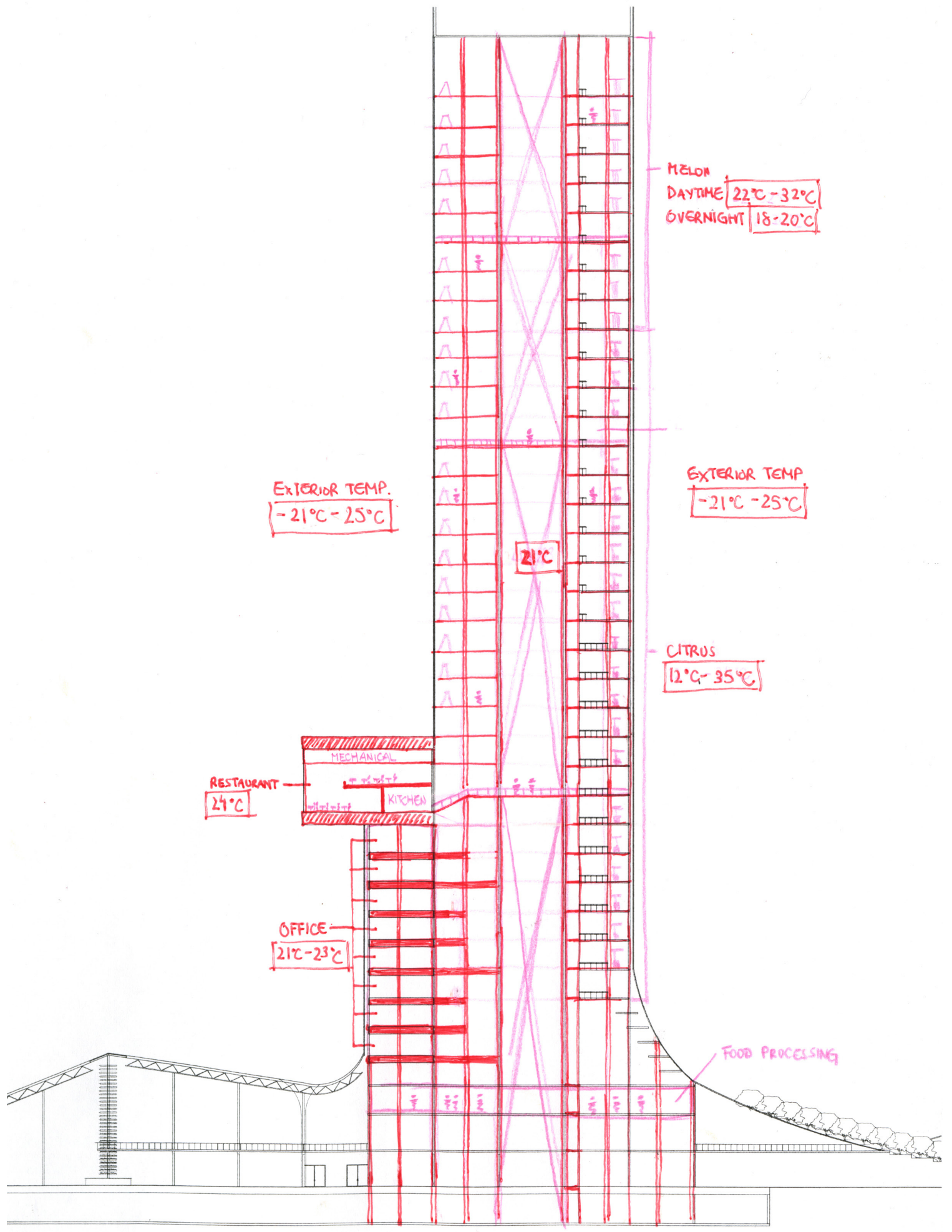

Winter temperatures were used to show the greatest temperature differentials 
Section 6 :

Design

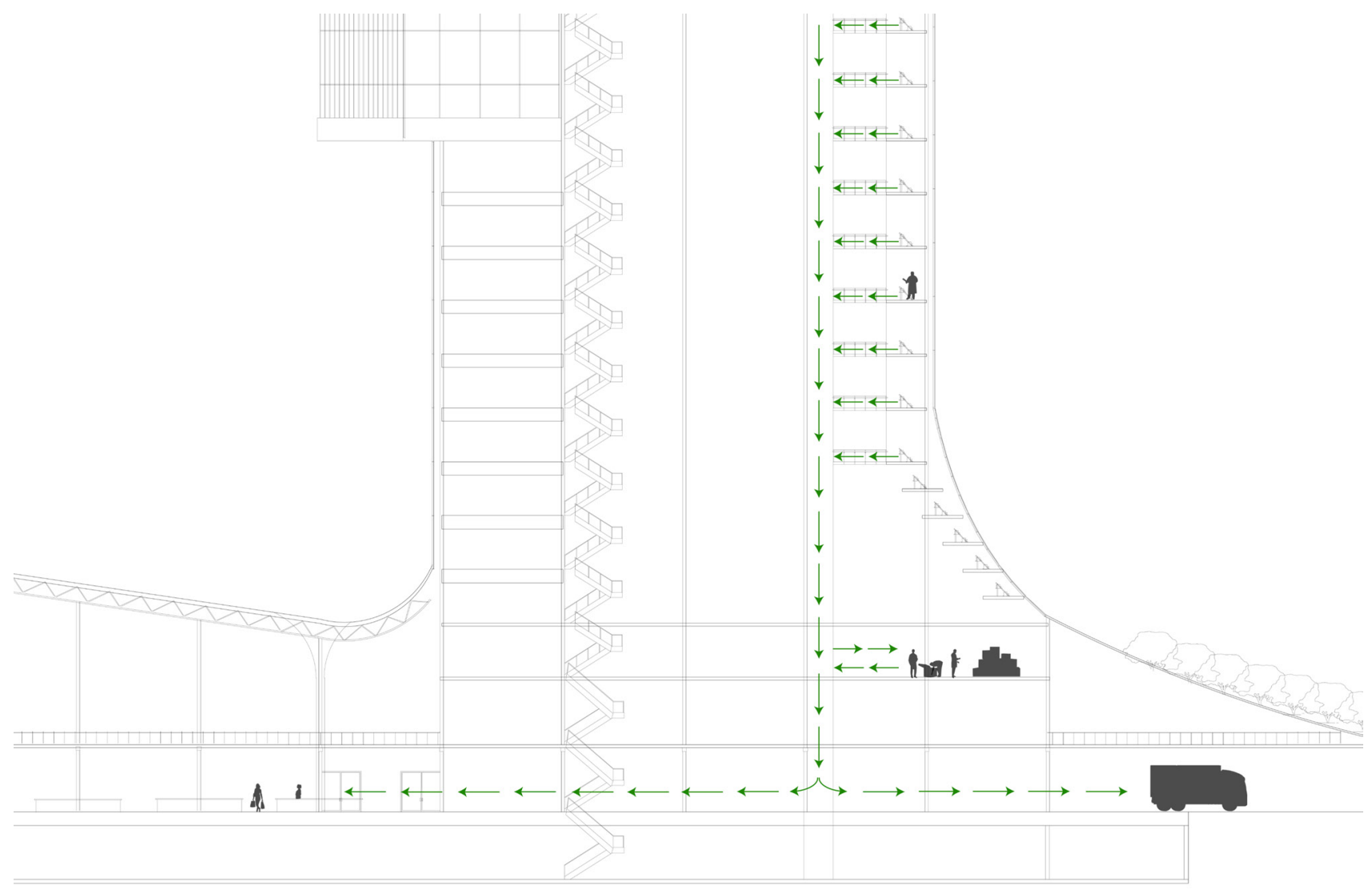

Food Production Diagram Section 
Section 6 :

Design

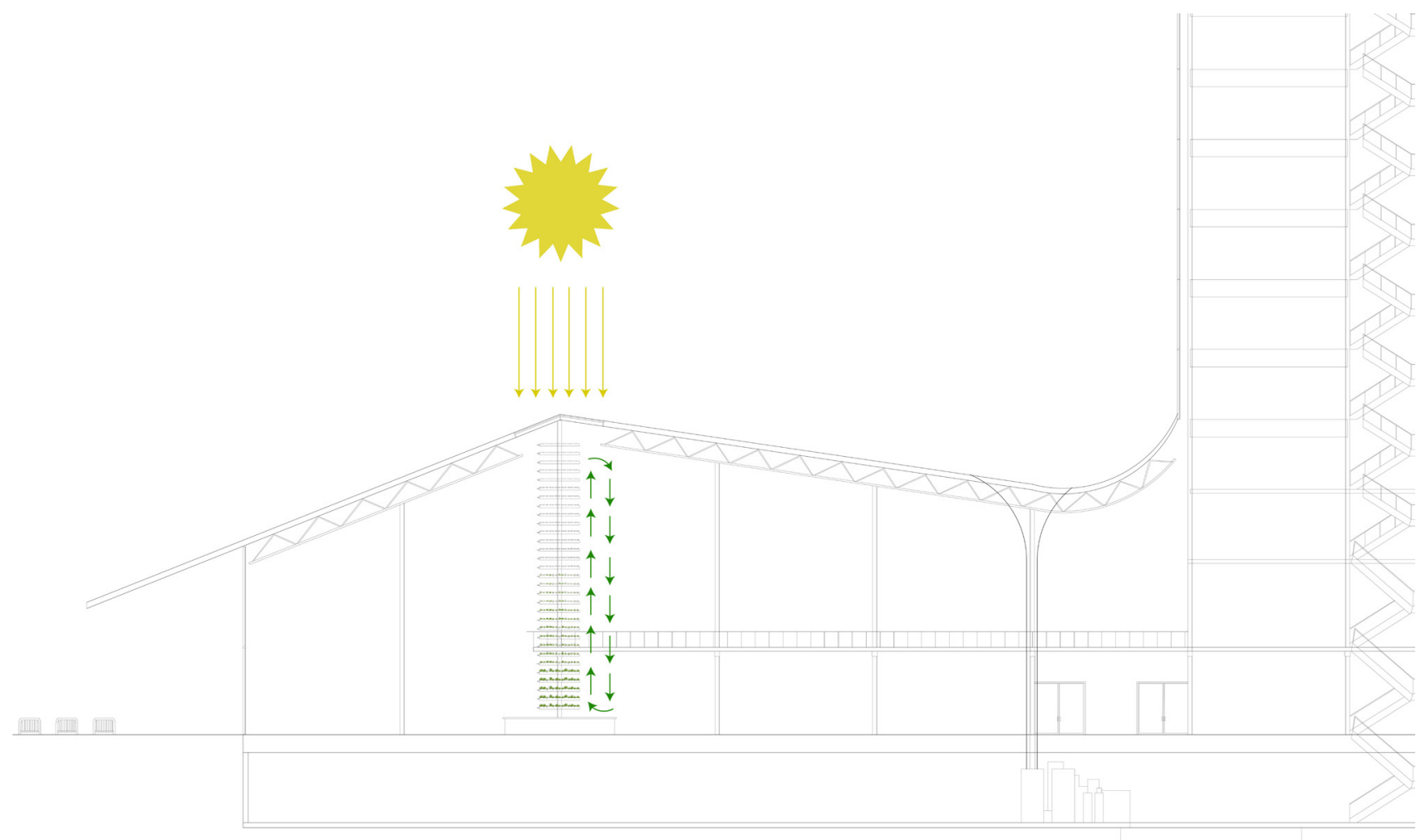

Market Hydroponics Diagram Section 
Section 6 :

Design

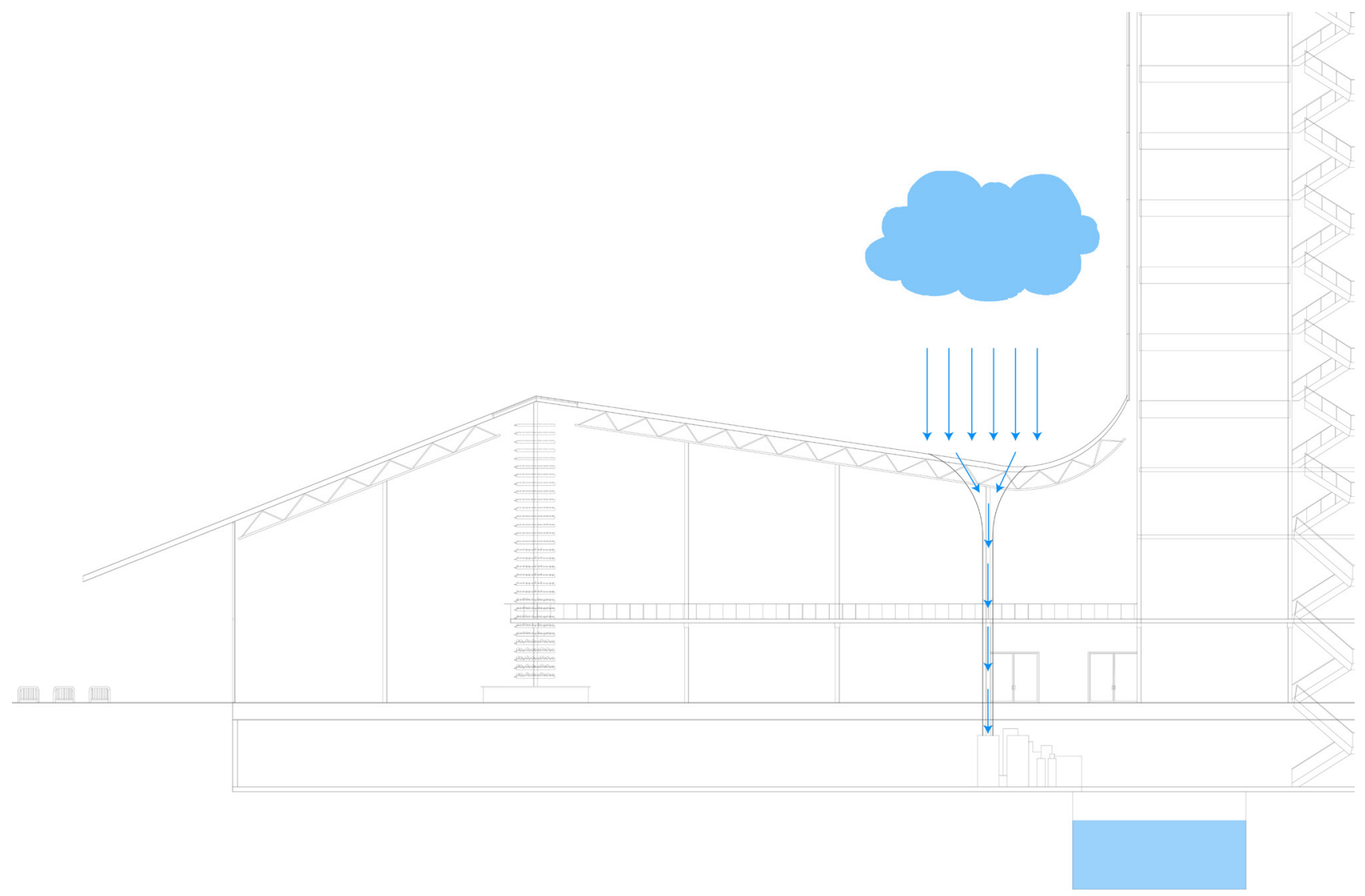

Water Filtration Diagram Section 
Section 6 :

Design

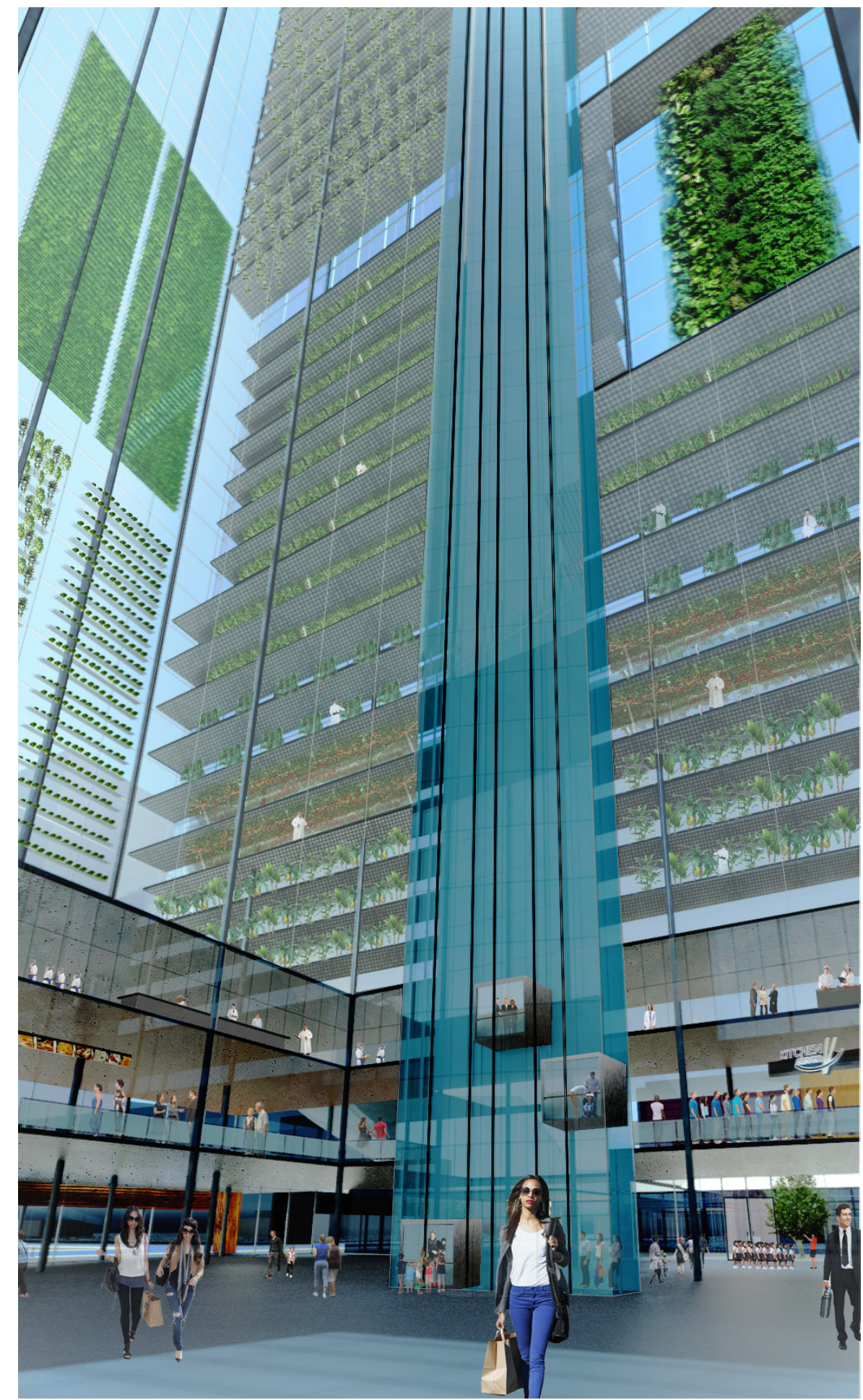

Render View of Tower Interior 
Section 6 :

Design

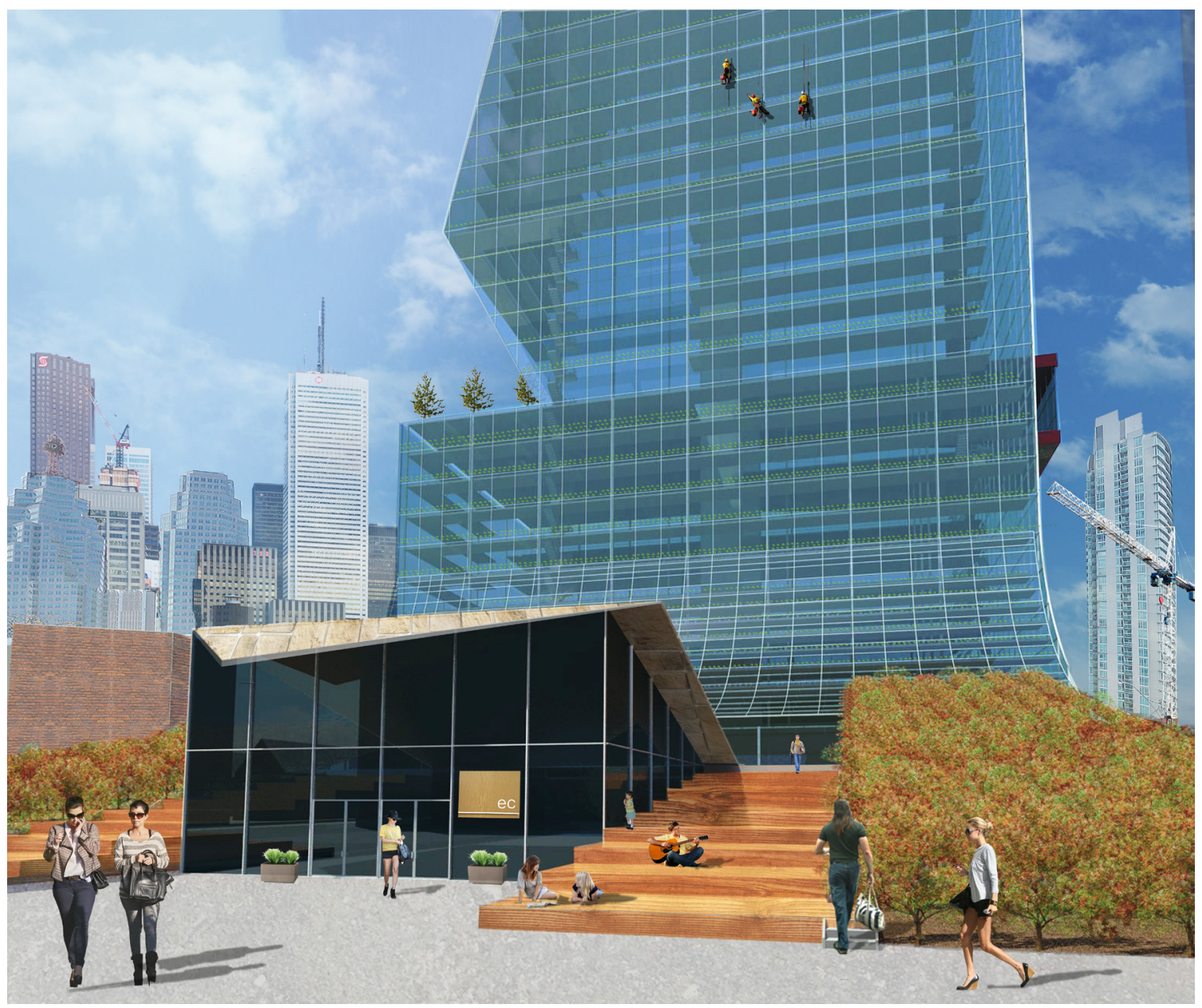

Render View of Southern Facade 
Section 6 :

Design

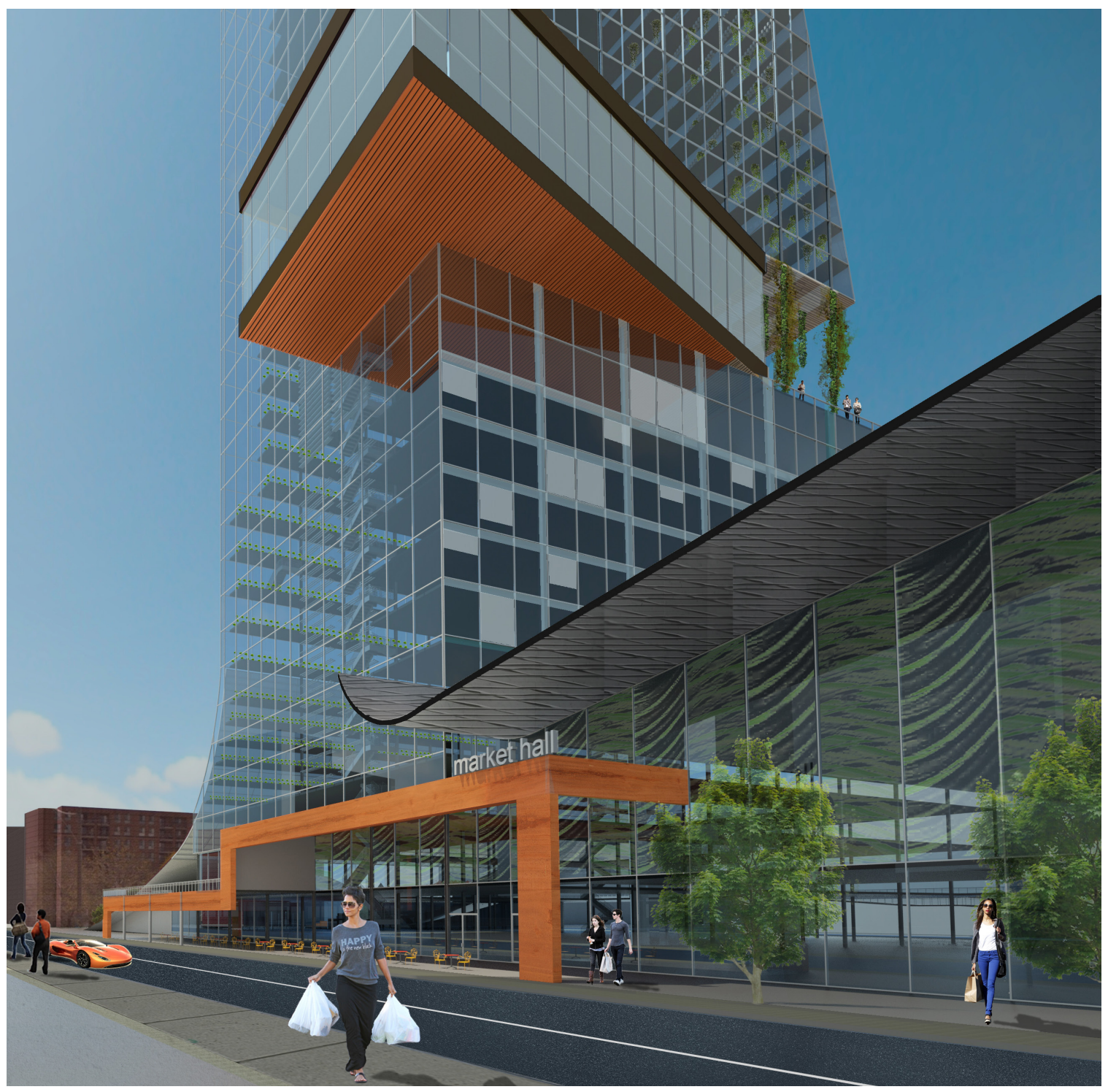


Section 6 :

Design

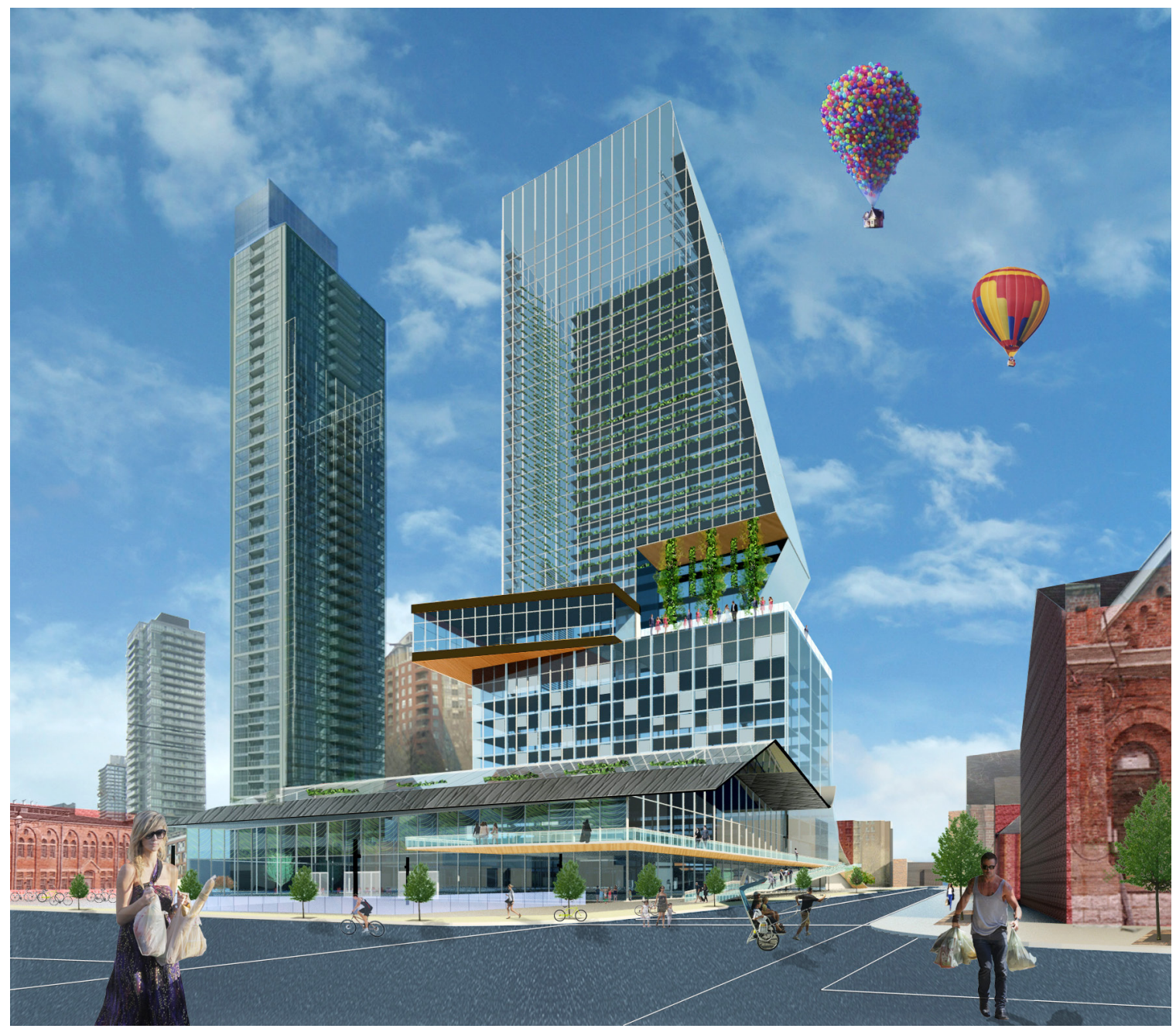


Section 6 :

Design

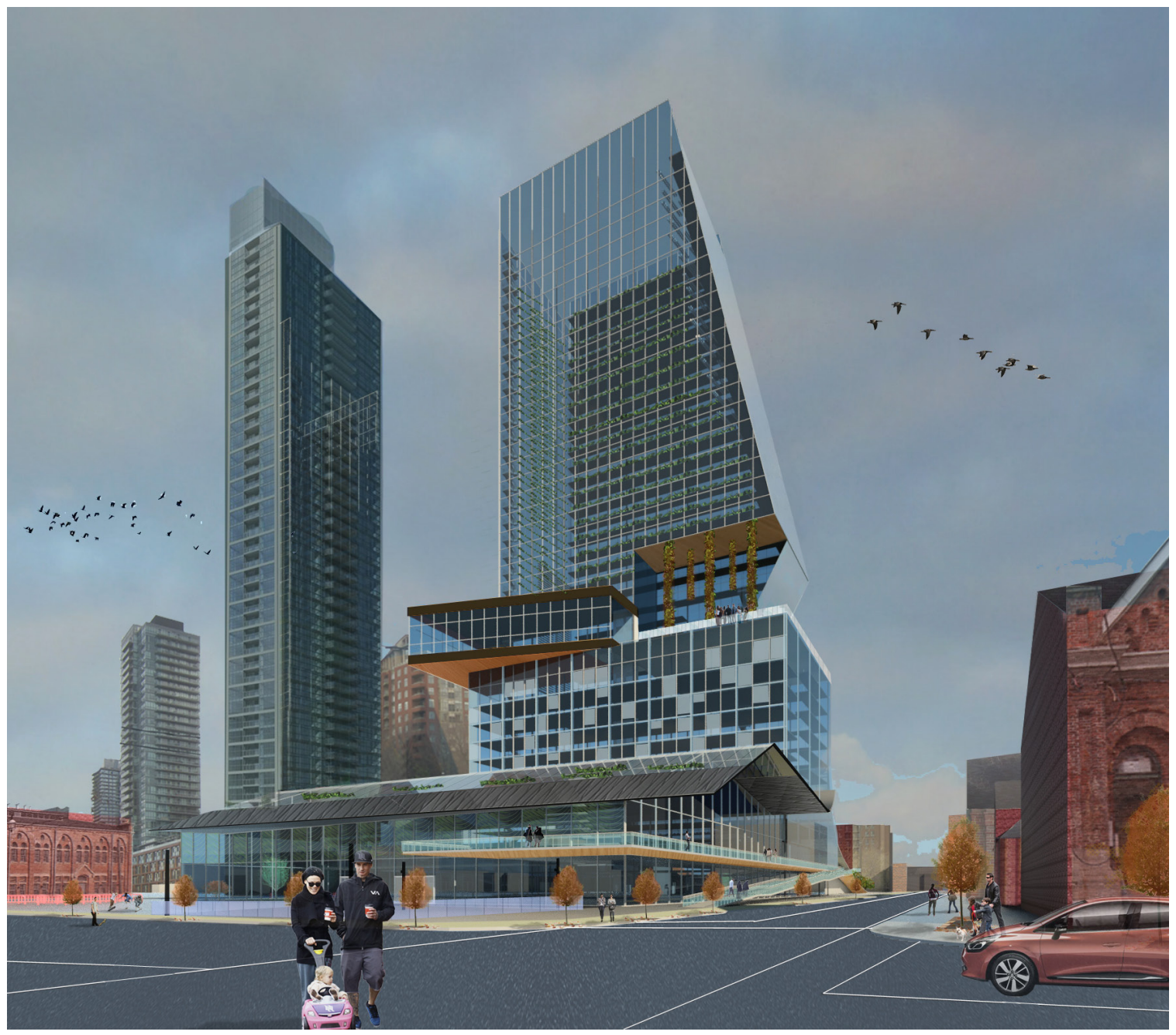


Section 6 :

Design

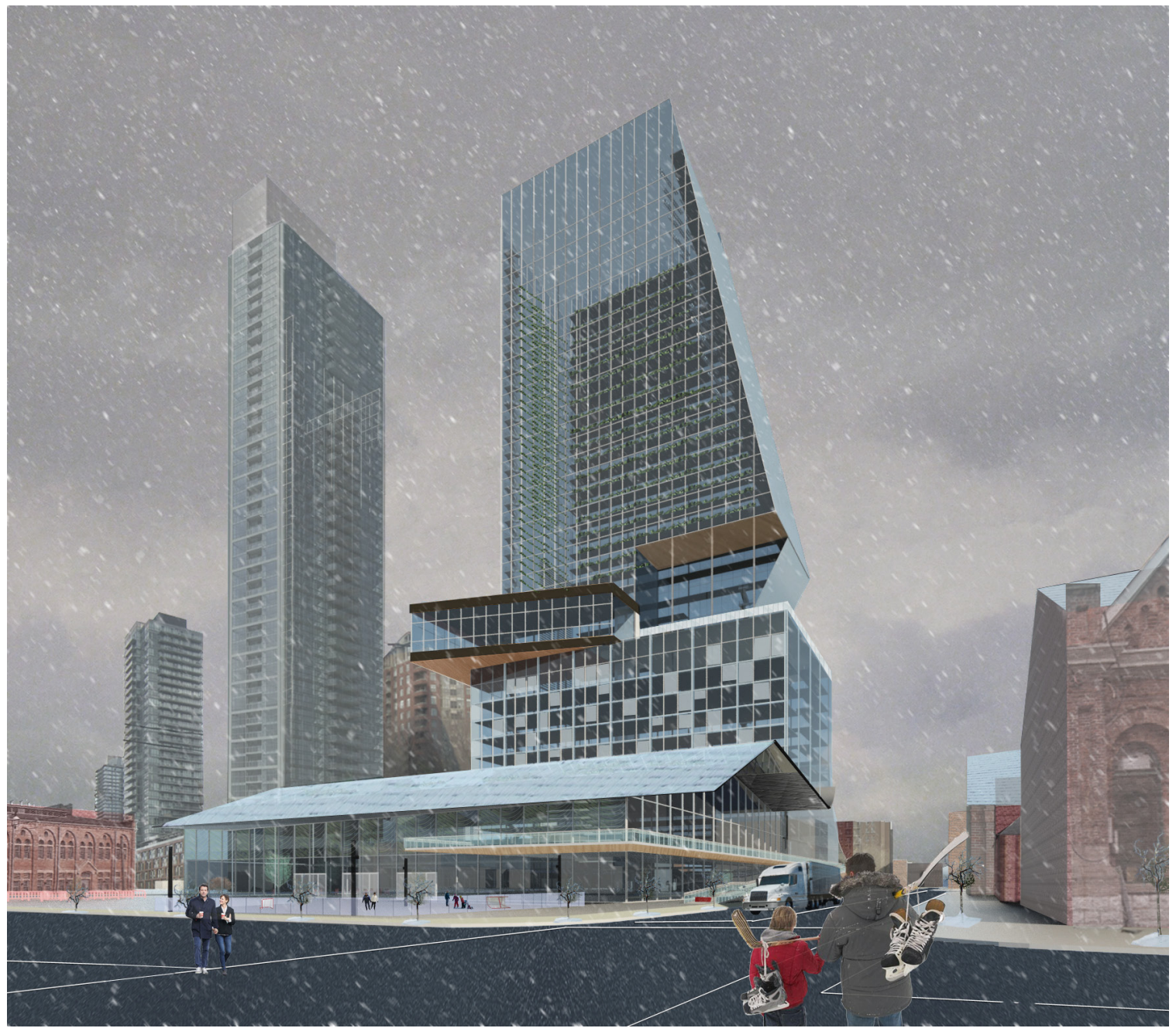


Section 6 :

Design

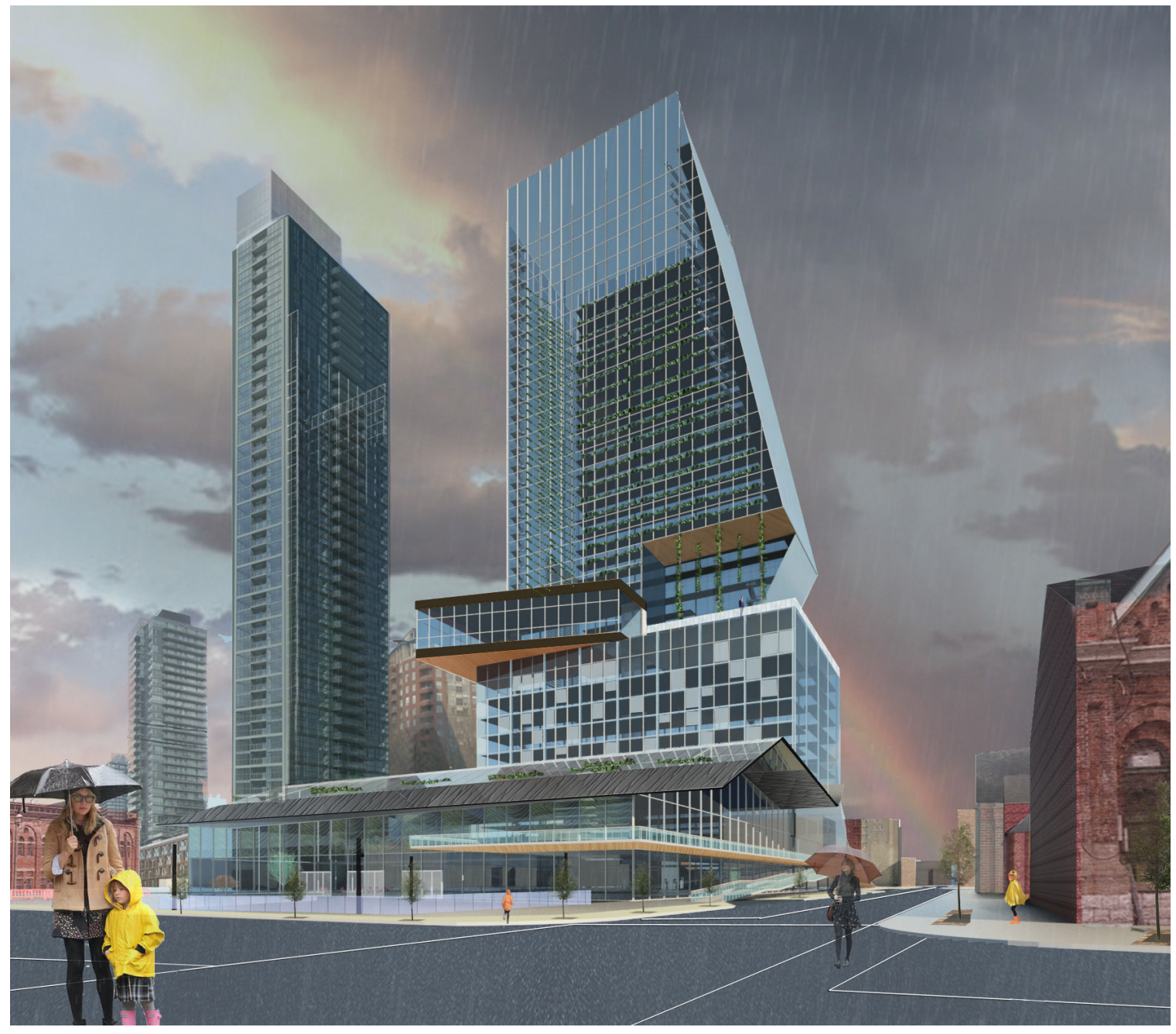

Render View of Northern Facade Spring 
Section 6 :

Design

\section{Section 6 Endnotes}

1. "About Us". Schmidt Hammer Lassen Architects. Accessed March 27, 2014. <http://shl.dk/eng/\#/home/about-us/ >

2. Despommier 2010, 183

3. "The History of the Distillery District" The Distillery Historic District. Accessed

November 13, 2013.

$<$ http://www3.thedistillerydistrict.com/our-story/history-of-the-distillery-district/>

4. "The History of the Distillery District" The Distillery Historic District.

5. "The History of the Distillery District" The Distillery Historic District.

6. "The History of the Distillery District" The Distillery Historic District.

7. "The History of the Distillery District" The Distillery Historic District.

8. "Upcoming Events" The Distillery District. Accessed March 31, 2014 <http://www3.thedistillerydistrict.com/events/>

9. Barnard, Linda. "Toronto's Distillery District evolves from tourist attraction to local destination". The Toronto Star. Last modified June 5, 2013.

<http://www.thestar.com/life/2013/06/05/torontos_distillery_district_evolves_from_tourist attraction_to_local_destination.html> 


\section{Conclusion}

The design project achieves a basic level of self-sufficiency and food security for the Distillery District as well as the ability to provide local produce for the city of Toronto. As the recent demand for local produce has cycled back into the city, the urban fabric must adapt to accommodate. The concerns regarding the current food processing model, its negative environmental impacts, and the world's growing urban population ensures that the local food initiative will continue to grow and manifest itself physically in cities. Toronto has seen a rise in the number of local food markets as well as programs around the city to educate communities about the new food movement. The design project is a structure that embodies these ideas in a practical means with a marketplace for visitors to access fresh produce, and education centre to create awareness, offices that can house councils and policy makers. The size of the farming tower blends in with the city skyline and its street level harmonizes with the Distillery District.

The hydroponic systems applied to the indoor farming of crops are no longer uncommon to the commercial market. Restaurants and households use these systems on a small scale as well as for large scale indoors farms and greenhouses. Although the design project implements these systems in its tower to provide for one neighbourhood, the city of Toronto would need multiples of these structure in order to render the whole city self-sufficient. At such a scale, these vertical farms may not seem as practical. With over 25 districts within the central core of Toronto, and over 80 districts downtown excluding the North York, East York, Etobicoke, and the Greater Toronto Area, this demonstrates the extent of what is required.

This thesis was also more than answering a food security question. Architecture was used as a tool to solve problems dealing with urban farming as well as social aspects to the local food movement. Food in itself is a social object and act. The design of the 
Section B:

Conclusion

orchard, public plaza, and weaving levels of exterior space speaks to the community and changes their interaction with the neighbourhood, each other, and relationship with food. The city of Toronto is made of districts that began with the ideas of food. The structure is a public exhibition of what Toronto was, what it needs, and what it should be. 


\section{Section C: Appendix}

\section{The GMO Debate}

Genetically Modified Organisms are plants or animals created through the gene splicing techniques of biotechnology. This experimental technology merges DNA from different species, creating combinations of plant, animal, bacterial and viral genes that cannot occur in nature or in traditional crossbreeding ${ }^{1}$. The first genetically modified plant was produced in 1984 , with commercial planting beginning in $1996^{2}$. North America is now centre of a controversial divide between those who support genetically modified foods and those who share a suspicious against them. The group opposed to GMOs fear that the testing done on present crops have not been sufficient to allow consumption on the commercial market. Many are suspicious of potential negative side effects of these very new products and calling for GMO labeling on all food products that contain genetically modified ingredients. This may be hard as $70 \%$ of all processed foods contain some genetically modified product while about two thirds of all foods in commercial grocery stores are genetically engineered ${ }^{3}$. In opposition, many argue GMOs have the potential to decrease world hunger in countries populated with famine and harsh agricultural conditions. The GMO debate is a very large controversy with many detailed arguments for both parties and will not be featured in this thesis.

\section{Organic Foods}

Organic foods are normally associated with local produce in the new food movement. The organic food market has drastically expanded from specialty stores to possession of entire sections in commercial supermarkets. In 2010 , the organic industry in the United States totalled about $\$ 26.7$ billion and continues to grow as new food movements become more widespread ${ }^{4}$. The term "organic" refers to the way farmers grow and process agricultural products, such as fruits, vegetables, grains, dairy products and meat ${ }^{5}$. Organic farming practices do not use today's conventional methods of 
chemical fertilizers and pesticides, but more natural means such as manure fertilizers. Organic eating is can be related to the increased consumer fear of genetically modified foods in which consumers are seeking alternatives to commercial produce grown in today's conventional methods. Many people are unaware that under government label regulation, foods grown with copper sulfate and cyanide products are still considered "organic". In the past two years, nearly half of the organic fruits and vegetables tested across Canada contained pesticide residue ${ }^{6}$. Organic foods have become a debatable topic as more consumers follow the trend while others are becoming more skeptical about organic farming practices. Still, as demand increases for organic products, under the belief that they are safer and healthier, prices for organic foods will continue to stay above food grown under conventional food methods. The debate about organic foods will not be a focus in this thesis.

\section{Food Recalls}

The risks of large scale food production have recently become much harder to ignore as media attention has surged. Many food companies have grown so large and their distribution lines so internationally dispersed that any type of contamination scare could potentially affect millions of customers around the globe. For example, when Bovine Spongiform Encephalopathy, commonly known as "Mad Cow Disease", was discovered in 2003 in Alberta, international borders for importing Canadian beefwere immediately shutdown ${ }^{7}$. The embargo carried on for two more years, the Canadian beef industry lost more than $\$ 4$ billion, and it took years for the industry to recover. Another example is the 2008 Listeria outbreak in Canada in which 22 people died and hundreds became ill from meat processed by Maple Leaf Food, one of the largest food companies in Canada ${ }^{8}$. As more of the food the public consumes come from processing and manufacturing plants, the number of food recalls continues to rise each year. Between October 2, 2013 and December 20, 2013, there have been 49 food recall warnings classified as "high risk" posted by the Canadian Food Inspection Agency ${ }^{9}$. As outsourcing, importing, and factory foods began to stock the shelves of grocery stores and consumer households, local food seems to have disappeared from today's standard lifestyle in Toronto. I think this is too sensationalistic - either remove or temper it down. I do not think it adds to your argument. 
Section B :

Appendix

\section{Appendix Endnotes}

1. "What Is GMO." The NonGMO Project. Accessed February 5, 2014. <http://www.nongmoproject.org/learn-more/what-is-gmo/>

2. Cockrall-King 2012, 43

3. Cockrall-King 2012, 43

4. "Organic Food: Are they safer? More nutritious?" Mayo Clinic. Accessed February 5, 2014. <http://www.mayoclinic.org/organic-food/art-20043880>

5. "The Problem with Organic Food" World and Society. Last modified March 14, 2013

<http://worldandsociety.wordpress.com/2013/03/14/the-problem-with-organic-food/>

6. Levasseur, Joanne,Vera-Lynn Kubinec. "Pesticide residue found on nearly half of organic produce" CBC News. Last modified January 9, 2014

$<$ http://www.cbc.ca/news/canada/manitoba/pesticide-residue-found-on-nearly-half-of-organicproduce-1.2487712>

7. Charlebois, Sylvain. "The Sad State of Canada's Beef Industry." Troy Media. Last modified October 5, 2012.

Ladner 2011, 232

http://www.troymedia.com/2012/10/05/the-sad-state-of-canadas-beef-industry/>.

9. "Food Recall Warnings - High Risk." Government of Canada,Canadian Food Inspection Agency. Accessed January 2, 2014

<http://www.inspection.gc.ca/about-the-cfia/newsroom/food-recall-warnings/eng/12990763820 77/1299076493846> 


\section{Bibliography}

“A Little Piece of History”. St. Lawrence Market. Accessed March 27, 2014.

<http://www.stlawrencemarket.com/history>

“About” Toronto Food Policy Council. Accessed March 31, 2014. $<$ http://tfpc.to/about>

“About Skyline Farms." Skyline Farms. Accessed February 4, 2014. <http://skylinefarms.ca/index.php/about>

"Aeroponics, Aeroponic Gardening, Hydroponics." Tower Garden. Accessed February 4, 2014. <https://www.towergarden.ca/what-is-tower-garden/how-it-works/aeroponics>

“Aquaponics UK." Aquaponics UK. Accessed January 22, 2014. $<$ http://www.aquaponics.org.uk/>.

"AquaRanch - Systems, Tilapia, Produce, and Basil Vinaigrettes." AquaRanch - Systems, Tilapia, Produce, and Basil Vinaigrettes. Accessed January 22, 2014. <http://www.aquaranch.com/index.html>.

Barnard, Linda. "Toronto's Distillery District evolves from tourist attraction to local destination". The Toronto Star. Last modified June 5, 2013. <http://www.thestar.com/life/2013/06/05/torontos_distillery_district_evolves_from_tourist_attraction_ to_local_destination.html>

Besthorn, Fred H. "Vertical Farming: Social Work and Sustainable Urban Agriculture in an Age of Global Food Crises." Australian Social Work 66.2 (2013): 187-203. Accessed July 31, 2013. doi:10.1080/031 2407X.2012.716448

Biggs, Steven. "High Off the Hog: Hogtown as Food-Processing Hub." in The Edible City: Toronto's Food from Farm to Fork, edited by Christina Palassio and Alana Wilcox, 32-37. Toronto: Coach House, 2009.

"Canadian Aquaponics - Canada's Source For Aquaponic Information and News." Coming Soon: Toronto's First Commercial Aquaponic Farm. Accessed January 22, 2014.

<http://www.canadianaquaponics.com/2014/01/coming-soon-torontos-first-commercial.html>.

Charlebois, Sylvain. "The Sad State of Canada's Beef Industry." Troy Media. Last modified October 5, 2012. <http://www.troymedia.com/2012/10/05/the-sad-state-of-canadas-beef-industry/>.

Cho, Renee. "Vertical Farms: From Vision to Reality - State of the Planet." State of the Plant. Last modified October 1, 2011.

<http://blogs.ei.columbia.edu/2011/10/13/vertical-farms-from-vision-to-reality/>.

Cockrall-King, Jennifer. Food and the City: Urban Agriculture and the New Food Revolution. Amherst, NY: Prometheus, 2012.

Coping With Water Scarcity: An Action Framework for Agriculture and Food Security. United Nations Food and Agriculture Organization. 2008.

Cuthbert, Pamela. "A Pressure Cooker Simmers on the Back Burner." in The Edible City: Toronto's Food from Farm to Fork, edited by Christina Palassio and Alana Wilcox, 54-57. Toronto: Coach House, 2009.

Despommier, Dickson D. The Vertical Farm: Feeding the World in the 21st Century. New York: Thomas Dunne/ St. Martin's, 2010. 
Bibliography

Dotan, Hamutal. "For the Love of a Good Burger." in The Edible City: Toronto's Food from Farm to Fork, edited by Christina Palassio and Alana Wilcox, 160-165. Toronto: Coach House, 2009.

Farm, Mark. "Greenhouse Toronto, Once Upon a Time" in The Edible City: Toronto's Food from Farm to Fork, edited by Christina Palassio and Alana Wilcox, 140-147. Toronto: Coach House, 2009.

"FarmedHere: The Freshest, Healthiest and the Most Local Greens in Chicago." FarmedHere. Accessed February 4, 2014.

$<$ http://farmedhere.com/\#products>

"FAO." Food and Agriculture Organization of the United Nations. Accessed February 2, 2014. $<$ http://www.fao.org/home/en/>

"Food Policy." Foodshare Toronto. Accessed January 21, 2014. <http://www.foodshare.net/food-policy>.

"Food Recall Warnings - High Risk." Government of Canada,Canadian Food Inspection Agency. Accessed January 2, 2014.

$<$ http://www.inspection.gc.ca/about-the-cfia/newsroom/food-recall-warnings/eng/1299076382077/129 9076493846>

"Grow TO: An Urban Agriculture Action Plan for Toronto (2012)." Toronto Food Policy Council, Oct, 2012. Accessed Sept 16, 2013. <http://tfpc.to/wordpress/wp-content/uploads/2012/08/GrowTO_ActionPlan_Oct161.pdf>.

Halweil, Brian. "Worldwatch Paper \#163: Home Grown: The Case For Local Food In A Global Market." World watch Institute. Accessed January 19, 2014. <http://www.worldwatch.org/node/827>.

Hardwicke, Chris. "Reviving St. Andrew's Market." in The Edible City: Toronto's Food from Farm to Fork, edited by Christina Palassio and Alana Wilcox, 246-251. Toronto: Coach House, 2009.

"Here at Epcot They Are Using Various Hydroponics Systems to Help Change the World: Part III : The Land." ThePhotoGardenBee RSS. Last modified January 5, 2010.

<http://thephotogardenbee.com/2010/01/05/aeroponics-gardens-at-epcot-part-iii-the-land/>

Hood, Sarah B. "Pickerel, Pork, and Presidents Choice: A Historical Food Map of Toronto." in The Edible City: Toronto's Food from Farm to Fork, edited by Christina Palassio and Alana Wilcox, 14-21. Toronto: Coach House, 2009.

"How to Feed the World in 2050". United Nations Food and Agriculture Organization. Accessed March 29, 2014. <http://www.fao.org/fileadmin/templates/wsfs/docs/expert_paper/How_to_Feed_the_World_in_2050. $\mathrm{pdf}>$

james, Scott. "The Future of Food" Forbes. Last modified September 28, 2010. <http://www.forbes.com/sites/csr/2010/09/28/the-future-of-food/>

Johnson, Lorraine. "Revisiting Victory, Garden Past, Garden Future." in The Edible City: Toronto's Food from Farm to Fork, edited by Christina Palassio and Alana Wilcox, 58-65. Toronto: Coach House, 2009

"Kensington Market Historical Society." Kensington Market Historical Society. Accessed December 22, 2013. <http://www.kmhs.ca/a-residential-marketplace/>.

Kretschmer, Fabian, and Malte E. Kollenberg. "Vertical Farming: Can Urban Agriculture Feed a Hungry World?" SPIEGEL ONLINE. Last modified July 22, 2011. $<$ http://www.spiegel.de/international/zeitgeist/vertical-farming-can-urban-agriculture-feed-a-hungryworld-a-775754.html>.

Ladner, Peter. The Urban Food Revolution: Changing the Way We Feed Cities. Gabriola Island, BC: New Soci ety, 2011. 
Bibliography

"Living with the Land." Walt Disney World. Accessed January 28, 2014.

<https://disneyworld.disney.go.com/attractions/epcot/living-with-the-land/>

"Local Food" Livegreen Toronto. Accessed March 31, 2014.

<http://www.toronto.ca/livegreen/greenlife_localfood.htm>

“Local Food Chains" Canadian Food Inspection Agency. Accessed March 31, 2014. <http://www.inspection.gc.ca/food/labelling/food-labelling-for-industry/local-food-claims/eng/13681359 $27256 / 1368136146333>$

Mahanta, Siddhartha. "New York's Looming Food Disaster." The Atlantic Cities. Accessed January 2, 2014. <http://www.theatlanticcities.com/politics/2013/10/new-yorks-looming-food-disaster/7294/>.

"Revolution in Plant Growing." PlantLab. Accessed January 24, 2014. $<$ http://www.plantlab.nl/4.0/index.php/revolution-in-growing/>.

Rogers, Damian. "Ontario Food Terminal: Behind the Curtain." in The Edible City: Toronto's Food from Farm to Fork, edited by Christina Palassio and Alana Wilcox, 234-237. Toronto: Coach House, 2009

Taylor, Lisa. Your Farm in the City: An Urban Dweller's Guide to Growing Food and Raising Livestock. New York: Black Dog \& Leventhal, 2011.

"Chronology of the Distillery Historic District." The Distillery Historic District. Accessed November 13, 2013. $<$ http://www.distilleryheritage.com/PDFs/chronology.pdf>

"The Distillery District" A Shot of History". The Distillery Historic District. Accessed November 13, 2013. $<$ http://www.distilleryheritage.com/PDFs/shotofhistory.pdf>

"The History of the Distillery District". The Distillery Historic District. Accessed November 13, 2013. <http://www3.thedistillerydistrict.com/our-story/history-of-the-distillery-district/>

"Victorian Industrial Architecture at the Distillery District". The Distillery Historic District. Accessed November 13, 2013.

< http://www.distilleryheritage.com/PDFs/buildings/victorian.pdf>

Thomas, Geoff. "What's the Ideal Distance from Farm to Fork?" University of Toronto Magazine. Accessed Januart 19, 2014.

<http://www.magazine.utoronto.ca/leading-edge/pierre-desrochers-local-food-debate-myths-geoffthomas/>.

“Toronto's Architectural Gems—-the St. Patrick's (Queen St.) Market | Historic Toronto.” Historic Toronto. Accessed December 22, 2013. <http://tayloronhistory.com/2013/10/27/torontos-architectural-gemsthe-st-patricks-queen-st-market/>.

"Toronto Chinatown." History. Accessed December 23, 2013.

<http://www.toronto-chinatown.info/chinatown-history.html>.

"Upcoming Events" The Distillery District. Accessed March 31, 2014 $<$ http://www3.thedistillerydistrict.com/events/>

Verge, Stephanie. "The Love(ly) Bug: An Ode to Bees in the Era of Colony Collapse Disorder, Wasp Invasion and Rooftop Apiaries." in The Edible City: Toronto's Food from Farm to Fork, edited by Christina Palassio and Alana Wilcox, 134-139. Toronto: Coach House, 2009.

Wekerle, Gerda R. "Food Justice Movements: Policy, Planning, and Networks." Journal of Planning Education and Research 23 (2004): 378-386. Accessed July 31, 2013. doi: 10.1177/0739456X04264886 


\section{Secondary Bibliography}

"About Us”. Schmidt Hammer Lassen Architects. Accessed March 27, 2014. $<$ http://shl.dk/eng/\#/home/about-us/ >

Burr, Laura, and Jane Lac, and Ilona Burkot. "Putting a Price on Healthy Eating in Toronto." in The Edible City: Toronto's Food from Farm to Fork, edited by Christina Palassio and Alana Wilcox, 8491. Toronto: Coach House, 2009.

Céron-Palma, lleana, Jordi Oliver-Solà, Juan-Ignacio Montero, and Joan Rieradevall. "Barriers and Opportunities Regarding the Implementation of Rooftop Eco.Greenhouses (RTEG) in Mediterranean Cities of Europe." Journal of Urban Technology 19.4 (2013): 87-103. Accessed July 31, 2013. doi:10.1 080/10630732.2012.717685

Cormier, Brendan "A Pressure Cooker Simmers on the Back Burner." in The Edible City: Toronto's Food from Farm to Fork, edited by Christina Palassio and Alana Wilcox, 284-291. Toronto: Coach House, 2009.

"Genetically Engineered Foods - Why the Controversy?" The Real Truth. Accessed February 5, 2014. $<$ http://realtruth.org/articles/223-gefwtc.html>

Giedion, Siegfried. Mechanization Takes Command. New York: Oxford UP, 1948.

Heidegger, Martin. The Question Concerning Technology. 1954. Accessed March 26. <http://simondon.ocular-witness.com/wp-content/uploads/2008/05/question_concerning_technology. pdf>

Ottelé, Marc, Katia Perini, A.L.A. Fraaij, E.M. Haas, and R. Raiteri. "Comparative Life Cycle Analysis for Green Façades and Living Wall Systems." Energy and Buildings 43 (2011): 419-429. Accessed July 31, 2013. doi:10.1016/j.enbuild.2011.09.010

Sorkin, Michael. "New York City (Steady) State." Architectural Design: Scarcity July-Aug, 2012.

Thibert, Joël. "Making Local Planning Work for Urban Agriculture in the North American Context: A View from the Ground." Journal of Planning Education and Research 32 (2013): 349-57. Accessed July 31, 2013. doi: 10.1177/0739456X11431692

Underhill, Brownwyn. "A Tale of Three Peaches." in The Edible City: Toronto's Food from Farm to Fork, edited by Christina Palassio and Alana Wilcox, 38-43. Toronto: Coach House, 2009.

"What Is GMO." The NonGMO Project. Accessed February 5, 2014. <http://www.nongmoproject.org/learn-more/what-is-gmo/>

"Organic Food: Are they safer? More nutritious?" Mayo Clinic. Accessed February 5, 2014. $<$ <ttp://www.mayoclinic.org/organic-food/art-20043880>

"The Problem with Organic Food" World and Society. Last modified March 14, 2013. <http://worldandsociety.wordpress.com/2013/03/14/the-problem-with-organic-food/>

Levasseur, Joanne,Vera-Lynn Kubinec. "Pesticide residue found on nearly half of organic produce" CBC News. Last modified January 9, 2014. <http://www.cbc.ca/news/canada/manitoba/pesticide-residue-found-on-nearly-half-of-organic-pro duce-1.2487712> 


\section{Image Bibiliography}

Image 1 Hood, Sarah B. "Pickerel, Pork, and Presidents Choice: A Historical Food Map of Toronto." in The Edible City: Toronto's Food from Farm to Fork, edited by Christina Palassio and Alana Wilcox, 14-21. Toronto: Coach House, 2009.

Image 2 "The St. Lawrence Market, Past and Present" blogTO. Last modified January 11, 2011. $<$ http://www.blogto.com/city/2011/01/the_st_lawrence_market_past_and_present/>

Image 3 "10+ Things to do on the East end of Toronto" Canucks Without Borders. Last modified March 29, 2012. <http://canuckswithoutborders.wordpress.com/tag/neighborhoods/>

Image 4 Hood, Sarah B. "Pickerel, Pork, and Presidents Choice: A Historical Food Map of Toronto." in The Edible City: Toronto's Food from Farm to Fork, edited by Christina Palassio and Alana Wilcox, 14-21. Toronto: Coach House, 2009.

Image 5 "Meat Processing Industry" Historica Canada. Accessed March 29, 2014. $<$ http://www.thecanadianencyclopedia.ca/en/article/meat-processing-industry/>

Image 6 "Toronto Remembers the Home Front, 1939-1945" City of Toronto Archives. Accessed March 29, 2014.

<http://www1.toronto.ca/wps/portal/contentonly?vgnextoid=6fda757ae6b31410 VgnVCM100 00071d60f89RCRD\&vgnextchannel=7cb4ba2ae8b1e310VgnVCM10000071d60f89RCRD\& vgnextfmt=default>

Image 7 “The Green Revolution” Oecotextiles. Accessed March 30, 2014. <http://oecotextiles.wordpress.com/2011/06/09/the-green-revolution/>

Image 8 “The Times they are a Changin': The Meat Industry Then and Now” Victorian Golden Roast. Last Modified November 27, 2013. $<$ http://www.victoriangoldenroast.com.au/news-blog/the-times-they-are-a-changin-themeat-industry-then-and-now>

Image 9 Despommier, Dickson D. The Vertical Farm: Feeding the World in the 21st Century. New York: Thomas Dunne/St. Martin's, 2010.

Image 10 Despommier, Dickson D. The Vertical Farm: Feeding the World in the 21st Century. New York: Thomas Dunne/St. Martin's, 2010.

Image 11 Verge, Stephanie. "The Love(ly) Bug: An Ode to Bees in the Era of Colony Collapse Disorder, Wasp Invasion and Rooftop Apiaries." in The Edible City: Toronto's Food from Farm to Fork, edited by Christina Palassio and Alana Wilcox, 134-139. Toronto: Coach House, 2009.

Image 12 "Brickworks Farmer's Market" Whosaysglutenfreehastotastebad. Accessed March 31, 2014. <http://whosaysglutenfreehastotasebad.wordpress.com/2011/08/01/brickwork/>

Image 13 Despommier, Dickson D. The Vertical Farm: Feeding the World in the 21st Century. New York: Thomas Dunne/St. Martin's, 2010.

Image 14 "Self-contained Robotic Farms Offer Glimpse of Lunar Food Factories" Ganaderia Mexico. Accessed March 31, 2014 <http://ganaderiamexico.blogspot.ca/2012/12/self-contained-robotic-farms-offer.html>

Image 15 "Aquaponics System" Aquaponics System. Accessed March 31, 2014 $<$ http://www.aquaponicssystems.net/>

Image 16 Despommier, Dickson D. The Vertical Farm: Feeding the World in the 21st Century. New York: Thomas Dunne/St. Martin's, 2010.

Image 17 "Great fun at Florida Small Farms Conference" Shooflyfarmblog. Last Modified August 5, 2013. $<$ https://shooflyfarmblog.wordpress.com/tag/small-farms-and-alternative-enterprises-confer ence/>

Image 18।"Why we need to bring nature back into cities" BBC. Last Modified May 30, 2013 <http://www.bbc.com/future/story/20130530-bringing-nature-back-into-cities>

Image 19 "Real Live Vertical Farm Built In South Korea, Churning Out Lettuce" Treehugger. Last modified July 25, 2011 $<$ http://www.treehugger.com/green-food/real-live-vertical-farm-built-in-south-korea-churn ing-out-lettuce.html>

Image 20 Ng, Jaclyn. 2014. 
Section C :

Bibliography

Image 21 "The History of the Distillery District". The Distillery Historic District. Accessed November 13, 2013.

$<$ http://www3.thedistillerydistrict.com/our-story/history-of-the-distillery-district/>

Image $22 \mathrm{Ng}$, Jaclyn. 2014

Image $23 \mathrm{Ng}$, Jaclyn. 2013

Image $24 \mathrm{Ng}$, Jaclyn. 2011 